\title{
Biržų pilies statinių architektūra ir jos raida
}

\section{Evaldas Purlys}

Projektavimo ir restauravimo institutas

Universiteto g. 4, LT-01122 Vilnius

Vilniaus dailès akademijos Restauravimo katedra

Maironio g. 6, LT-01124 Vilnius

evaldas@pri.lt

Nuo pirmosios Biržu pilies pastatymo 1586-1589 m. ši reprezentacinị ansamblị plètė ir ịvairiai perstatinèjo penkios Radvilų kartos: Kristupas I (1586-1589), Kristupas II (1627-1640), Jonušas (1640-1655), Boguslavas (1661-1669), Liudvika Karolina (apie 1681-1686). Po pilies žūties 1704 m. praèjus 300 metų, galime kalbèti apie naują, iki šiol besitęsianti pilies statinių architektūros raidos etapą. Jame ypatingą reikšmę ịgavo senụjų statinių liekanų tyrimas ir išsaugojimas, buvusios architektūros ir jos konstrukcijų atkūrimas, autentiškų mūrų liekanų eksponavimas. Straipsnyje, remiantis istoriografine ir autoriaus sukaupta architektūros tyrimų bei ansamblio restauravimo ir atkūrimo medžiaga, pateikiamas išsamus Biržų pilies architektūros ir jos kaitos vaizdas. Daugelis išvadų daroma remiantis ilgamete darbų prie Biržų pilies ansamblio patirtimi.

Reikšminiai žodžiai: Biržų pilis, istorija, architektūros tyrimai, restauravimas, atkūrimas, paveldas. 


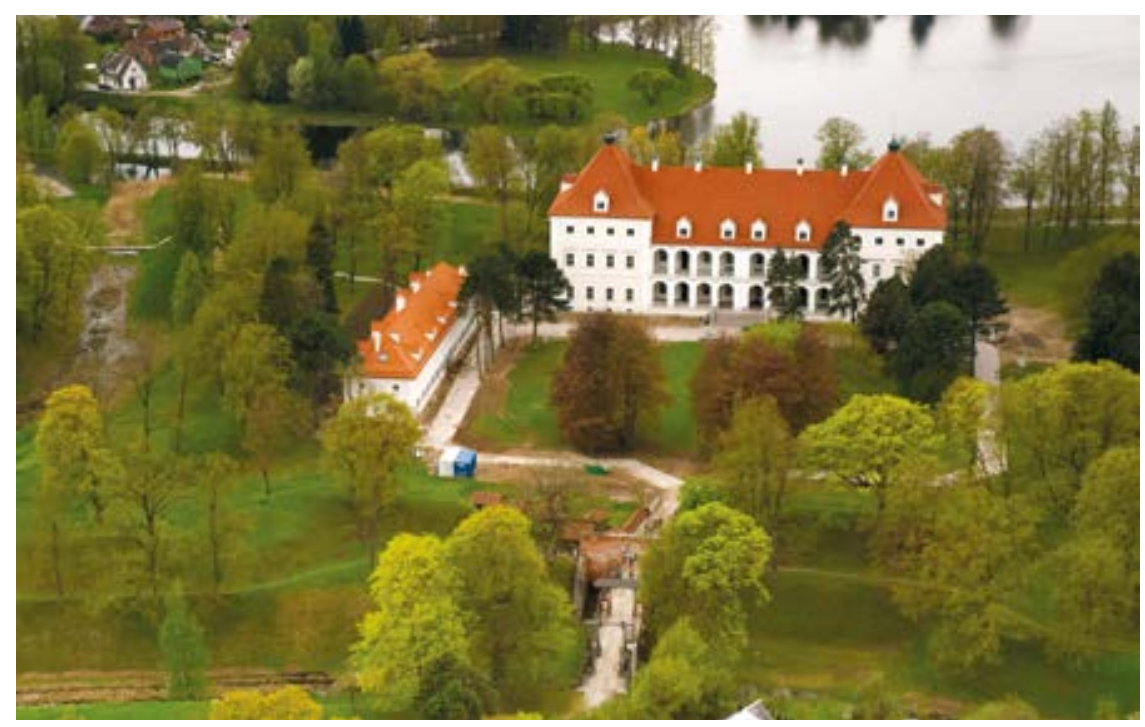

1.

Vaizdas ị pilị iš lèktuvo, Rimanto Šopio nuotrauka, Bird's-eye view of the castle 2013

Po Biržų pilies sugriovimo XVIII a. pradžioje ir po tris šimtmečius trukusio statybinių medžiagų ịvairioms statyboms ėmimo iš žmonių atminties buvo išnykę pilies statinių vaizdai, užsimiršo net jų vieta. Šlovingą tvirtovę ir gyvenimą joje liudijo tik gana gerai išsilaikę žemės pylimai ir kažkada didingų rūmų griuvėsiai. Praeities ženklai slypėjo archeologų tyrimo erdvėje ir senujų raštų lentynose. Po ilgos užmaršties 1869 m. Eustachijus Tiškevičius prakalbo apie Biržu pilies ir miesto istoriją. Prireikė daugelio specialistų - istorikų, archeologų, architektų - ilgamečio darbo, kad būtų išaiškintos šiandien turimos žinios apie pilies istoriją ir architektūrą [1 il.]. Didžioji dalis šių žinių paimta iš XX a. antros pusės - XXI a. pirmujjų metų istorikų Stasio Pinkaus ${ }^{2}$ ir Deimanto Karvelio ${ }^{3}$, archeologų Edmundo

1 Eustachijus Tiškevičius, Biržai. Žvilgsnis į miesto, pilies ir majorato praeitį, Šiauliai: Saulès delta, 1998, vertimas iš Eustachy Tyszkiewicz, Birže, rzut oka na przeszlosc miasta, zamku $i$ ordynacyi, St.-Petersburg, 1869.

2 Stasys Pinkus, „Biržų pilis“, in: Lietuvos pilys, Vilnius: Mintis, 1971, p. 245-276; Idem, Biržu pilis, Vilnius: Mintis, 1986, p. 1-48.

3 Deimantas Karvelis, Biržų pilies komplekso istoriniai tyrimai, 2008, in: VI „Lietuvos paminklai“ informaciniai fondai, b. LP-176 (K-2008); Idem, „Antrosios Biržų pilies (1659-1695) rūmų statyba ir interjero bei eksterjero kūrimas“, in: XVI-XVIIa. koklinès krosnys šiauriniame Lietuvos Didžiosios Kunigaikštystès paribyje: Konferencijos medžiaga, Kaunas: Žiemgalos leidykla, 2006, p. 17-36; Idem, „Bastioninės Biržų pilies arsenalas XVI-XVII a.“, in: Karo archyvas, t. XXIII, Vilnius: Lietuvos karo akademija, 2008, p. 39-73. 


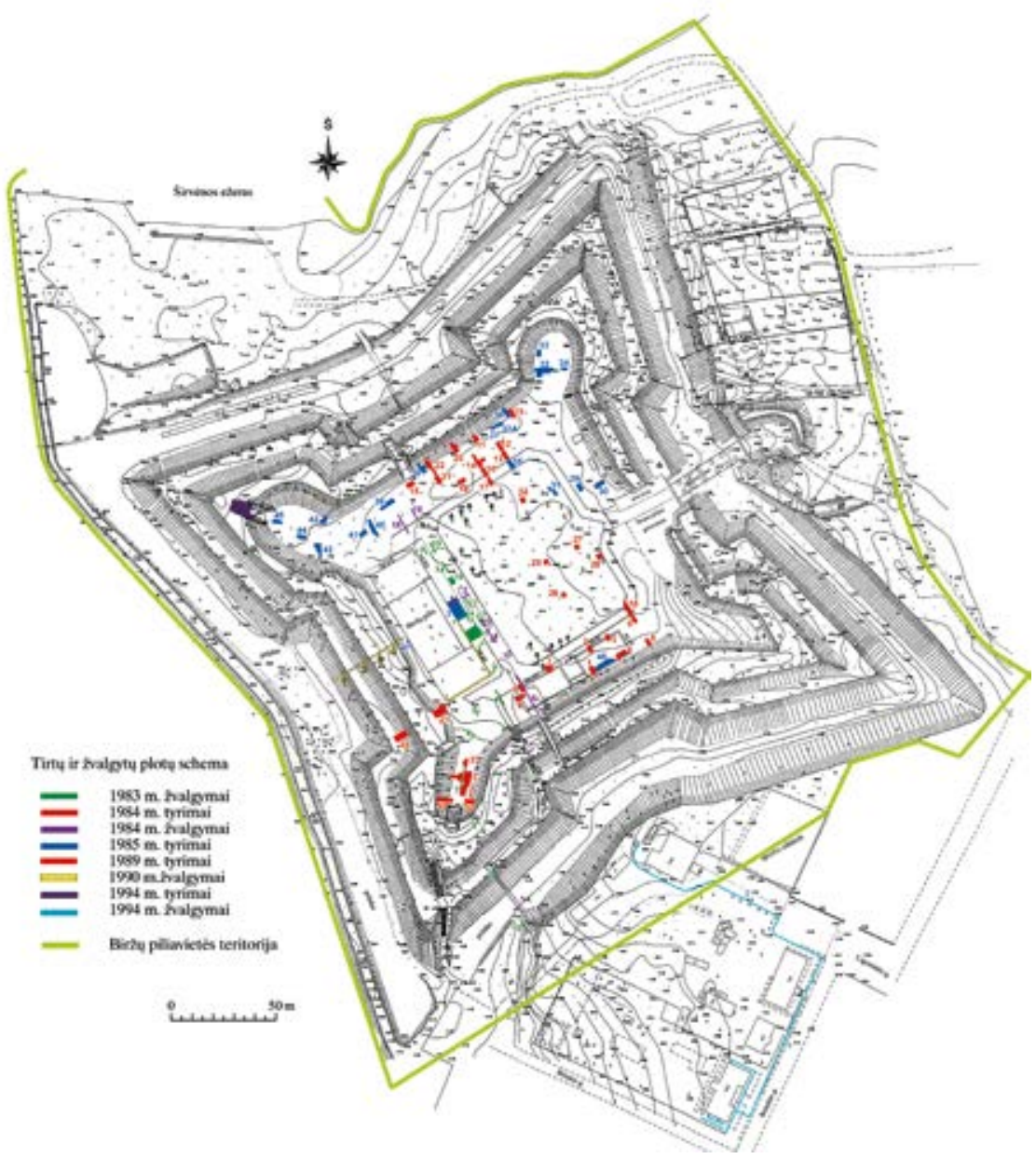

2.

Tyrinètų ir žvalgytų plotų schema, sud. Roma Songailaitè

Diagram of the explored areas

Skardžiaus, Algimanto Urbšto, Karolio Meko, Jono Genio, Romos Songailaitès ir kitų publikacijų bei ịvairių ịstaigų archyvuose saugomų tyrimų ataskaitų [2 il.]. Šio straipsnio autorius, remdamasis visomis žinomomis publikacijomis ir nepublikuota tyrimų medžiaga, ịvertindamas ilgametę savo darbu patirti prie ansamblio rekonstrukcijos, pateikia išsamų pastatų raidos vaizdą skirstydamas ji $i$ šešis etapus. Kiekviename istoriniame etape atliktų darbų išryškinimas ir sudaro pastarojo tyrimo vertę ir naujumą.

4 Roma Songailaitè, Tatjana Niedvarienè, „Biržų pilies archeologiniai tyrimai“, in: Biržu pilies ir senamiesčio archeologiniai rinkiniai: nuo seniausiu laiku iki XIX a. pradžios: Katalogas, Biržų krašto muziejus „Sèla“, 2016, p. 12-15. 
Pirmieji pilies statiniu architektūrą profesionaliai tyrinejjo archeologai ir architektai, pradėję išlikusių rūmų sienų tyrimo ir tvirtinimo darbus. Archeologų darbas šiuo atveju buvo skirtas pastatų liekanų paieškai ir tyrimams. E. Skardžiaus parengtos rūmų rūsių atkasimo ir tyrimo 1960-1962 m. ataskaitos tapo svarbiu rūmų istorijos pažinimo šaltiniu. 1961-1965 m. buvo išaiškinti arsenalo, rytinès parakinès, kelių pirmosios pilies statinių kontūrų fragmentai, kasinèta vartų ir tilto vietose. Sužinota apie mūrinius pirmosios pilies pylimų kiautus ir jų architektūrą, nubraižytas pilies vartų išlikusių mūrų planas, nustatyta vartų plano raida.

Inžinierius Napalys Kitkauskas, 1975 m. pristatydamas visuomenei argumentus, kuriais pagrịstas tilto ị pilies kiemą per fosą atkūrimo projektas, apibendrino istorinių dokumentų teikiamas žinias bei archeologinių tyrimų duomenis apie tiltą ir gynybinių pylimų architektūrą̧.

Archeologas J. Genys 1984-1985 m. tyrinëjo kareivines pietiniame ir vakariniame bastionuose, aptiko įvairių laikotarpių statinių liekanas keliuose pilies plotuose ${ }^{6}$. Archeologè R. Songailaitè kelis sezonus kasinèjo Kristupo I Radvilos rūmų plote, ịvairiose vakarinio bastiono atkarpose, 2008 m. ir 2010 m. atidengè arsenalo liekanas ir 2016 m. kartu su T. Niedvariene parašė archeologinių tyrimų pilies teritorijoje ir Biržų senamiestyje istoriją, sudarè archeologinių tyrimų ataskaitų sąrašą. Parašyti pirmieji straipsniai skirti pilies rūmų restauravimui ${ }^{7}$, jų restauravimo istorijai ${ }^{8}$.

Kadangi XX a. pabaigoje - XXI a. pirmaisiais dešimtmečiais daug sužinota apie Biržų pilies raidą, prasminga vèl išsamiai apžvelgti ansamblio architektūros raidą, ją skaidant ị šešis svarbius etapus: penkių Radvilu giminès atstovų (Kristupo I (1586-1589), Kristupo II (1627-1640), Jonušo (1640-1655), Boguslavo (1661-1669), Liudvikos Karolinos (1681-1686)) rezidavimo laiką ir laiką, kai pradèti vykdyti intensyvūs ansamblio tyrimai ir atstatymo darbai.

5 Napalys Kitkauskas, „Biržų antrosios pilies pylimai, fosa, redutas, tiltas“, in: Architektūros paminklai, t. 3, 1975, Vilnius: Mokslas, p. 136-156.

6 Jonas Genys, „1984-1985 m. archeologinių kasinėjimų Biržų pilyje rezultatai“, in: Architektūros paminklai, t. 11, Vilnius: Mokslas, 1988, p. 45-51.

7 Evaldas Purlys, „Biržų pilies rūmų restauracija 1978-1987 m.“, in: XVI-XVII a. koklinès krosnys šiauriniame Lietuvos Didžiosios Kunigaikštystès paribyje: Konferencijos medžiaga, Kaunas: Žiemgalos leidykla, 2006, p. 120-126; Idem, „Šildymo įrenginių išdèstymas Biržų pilies rūmuose“, in: XVI-XVII a. koklinès krosnys šiauriniame Lietuvos Didžiosios Kunigaikštystès paribyje: Konferencijos medžiaga, Kaunas: Žiemgalos leidykla, 2006, p. 58-66.

8 Evaldas Purlys, „50 metų Biržų pilies restauracijai“, in: XVI-XVII a. koklinès krosnys šiauriniame Lietuvos Didžiosios Kunigaikštystès paribyje: Konferencijos medžiaga, Kaunas:

Žiemgalos leidykla, 2006, p. 102-119. 


\section{Kristupo I Radvilos Perkūno pilis}

Pirmoji Biržų tvirtovė Kristupo I Radvilos (1547-1603) pastangomis statyta 1586-1589 m. pagal naujosios italų bastioninių piliu sistemos standartus. Užtvenkus per Biržus tekančias dvi upes, prie pilies susiformavo dirbtinis Širvenos ežeras. Žinių apie šios pilies statinių architektūrą teikia istoriniai šaltiniai ir atkasti rūmų, vartų ir gynybinių įtvirtinimų prie vartų fragmentai. Pirmoji pilis ir miestas pavaizduoti XVII a. pradžios Tomo Makovskio graviūroje [3 il.] 1625 m. švedų sudarytame tvirtovės plane [4 il.]. Dokumentai liudija, kad pilies kieme stovejo rūmai, arsenalas, arklidès, ịvairūs ūkinės paskirties pastatai, bastionuose buvo kazematai, kampiniai bokšteliai ir kiti gynybiniai statiniai. I pilies kiemą buvo patenkama per vartų pastatą prieš tai perèjus tiltą per gynybini pilies griovi - fosą. Panagrinèkime šiuos statinius smulkiau.

Gynybiniai pylimai. Stačiakampi pilies kiemą supo didysis pylimas. Kiemo kampuose buvo įrengtos bastionų aikštelès. Pylimų aukštis virš kiemo siekė 3-5 m. Švedų nubraižytame pjūvyje per fosą pavaizduotos mūrinės pylimų išorinius paviršius dengiančios sienos, parapetai virš jų pilies gynėjams [5 il.]. Kelis mūrinio pylimų kiauto fragmentus 1963-1965 m. atidengè archeologas Karolis Mekas. Mūrinio kiauto aukštis prie vartų buvo 10-12 m, storis - 2,5-3 m. Šiuo kiautu iš išorès buvo sutvirtinta dalis bastionų ir griovio kraštų. Iškilusi virš pylimų mūro kiauto dalis saugojo nuo kulkų ịgulos kareivius. Kiautas mūrytas iš lauko akmenų ir plytų. Analogą šiam gynybiniam įrenginiui iš dalies restauruotą galime matyti Nesvyžiaus Radvilų pilyje [6 il.]. Sprendžiant iš graviūros mūrinis kiautas formavo arba turejjo formuoti visą pilies ir jos bastionų išorinị kontūrą. Pilies išoriniai kontūrai taip pat apibrèžti ir švedų sudarytame $1625 \mathrm{~m}$. plane [žr. 5 il.]. Abejoti tokia, atrodytų, aiškiai išreikšta pilies gynybinių įtvirtinimų konstrukcija verčia klausimas, ką reiškia $1625 \mathrm{~m}$. plane rausva spalva, kuria nuspalvintas visas rytinis (ị kairę nuo įvažiavimo vartų) bastionas, dalis pietinio pylimo. Kasinėjimų ir archeologinės priežiūros metu, kasant tranšejas, pietvakarių ir pietryčiu pylimuose mūrinio kiauto liekanų nerasta' ${ }^{9}$ Tik rausva spalva pažymètoje kontūro dalyje buvo rastos mūrinio kiauto liekanos. Atrodo, tik rausva akvarele pažymètos pilies išorinio kontūro dalys sutvirtintos mūro 


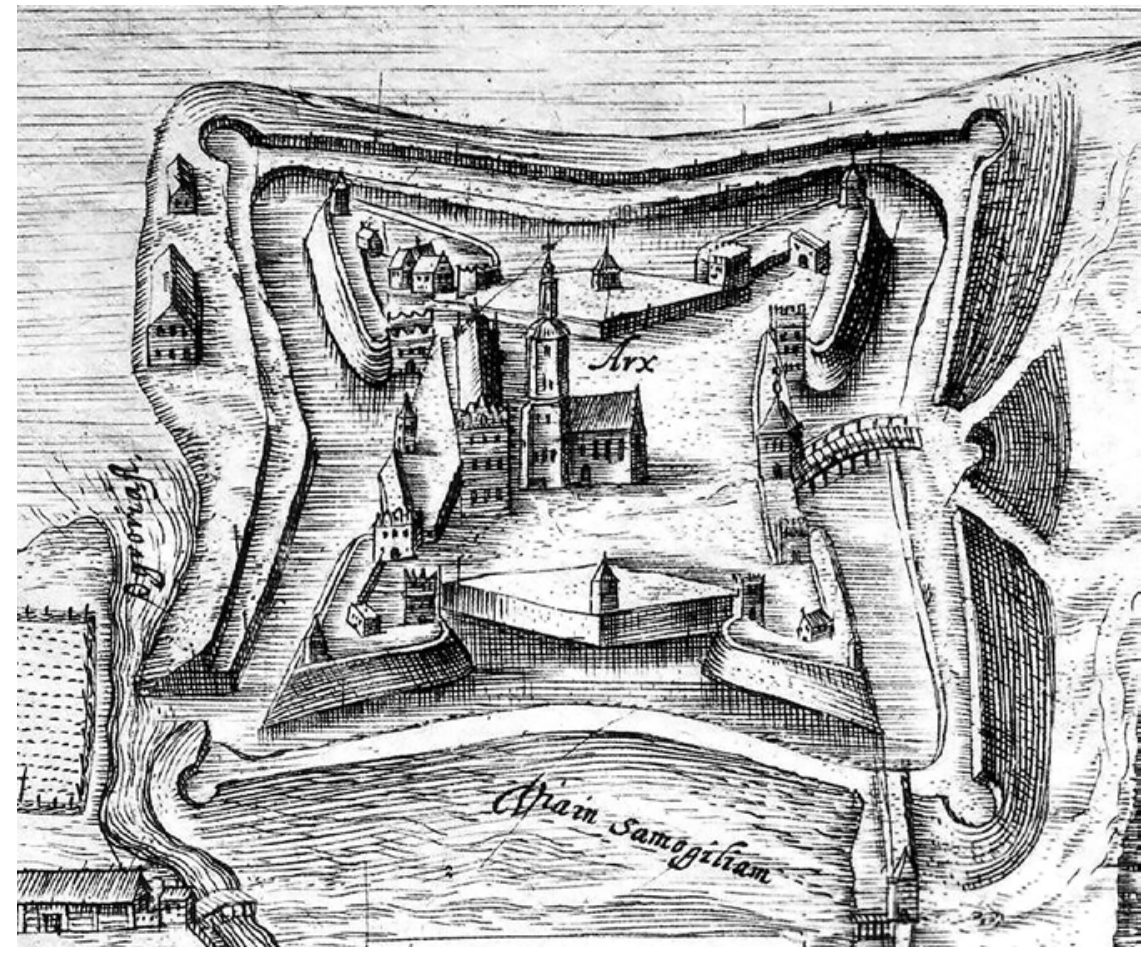

3.

Pilies vaizdas Tomo Makovskio graviūroje

View of the castle in T. Makowski's engraving

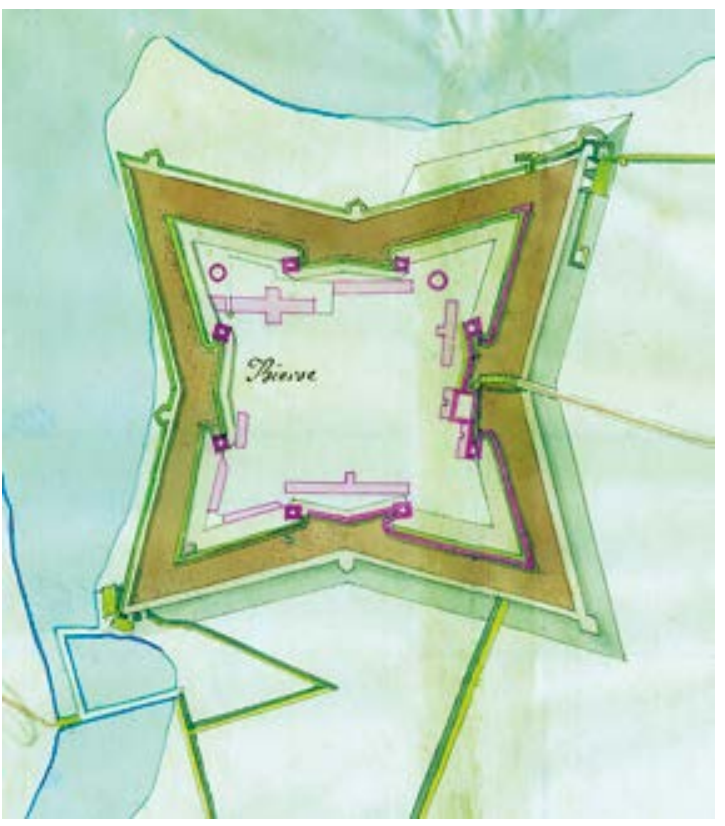

4.

Pilis švedų $1625 \mathrm{~m}$. sudarytame Biržų tvirtovès ir miesto gynybinių ittvirtinimų plane. Mūriniu kiautu sutvirtinta gynybinių pylimų dalis pažymėta rausva spalva

Castle in the Swedish plan of the Biržai fortress and the city's fortifications of 1625 . The part of the defensive ramparts reinforced with a brick shell is marked in pink 
kiautu. Kitur, matyt, pasitenkinta žemių pylimais, kurie būdami ne tokie statūs turejjo būti gerokai išsikišę už priekinès mūrinio kiauto kontūro linijos. Pilies fosos šlaitai iki galo nebuvo užbaigti iki pat jos sugriovimo 1625 metais. Darbus greičiausia nutraukè fundatoriaus mirtis $1603 \mathrm{~m} \cdot{ }^{10}$

Rümai. Jie buvo stačiakampio plano, su plotą ị dvi dalis skaidančia išilgine siena. Skersinės sienos formavo patalpas abipus išilginės sienos. Šis statinys buvo gerokai mažesnis nei vėliau Jonušo ir Boguslavo Radvilų statyti rūmai. Pietvakarinès ir vidurinès išilginès sienos mūrų liekanos slypi greta Jonušo ir Boguslavo Radvilų rūmų pamato ir po pylimu, šiaurès rytinès - po rūsių grindimis. Vidurinè išilginè, o greičiausia ir skersinès sienos buvo mūrytos ant arkinių pamatų [7 il.]. Tai patvirtina po 1990-1991 m. tyrimų archeologo J. Genio sudarytas preliminarus pirmosios pilies rūmų planas [8 il.]. Pirmame aukšte šiaurès vakarų gale būta dviejų maždaug $45 \mathrm{~m}^{2}$ dydžio patalpų ir dviejų $54 \mathrm{~m}^{2}$ dydžio patalpų, vidury - dvi 90 ir $75 \mathrm{~m}^{2}$ patalpos, pietryčių gale - $210 \mathrm{~m}^{2}$ dydžio salè su siaura $90 \mathrm{~m}^{2}$ patalpa šalia. Išorinių sienų pamatai - 1,5-1,56 m storio. Rūmų pirmo aukšto langai buvo su palangių nišomis. Atkasus visą pietvakarinę sieną būtų galima sužinoti, kiek langų buvo šioje sienoje ir kaip jie buvo išsidèstę. Su palangiu nišomis turèjo būti ir viršutinių aukštų langai. Galiniame, pietrytiniame, fasade T. Makovskio graviūroje pavaizduoti trys langai. Panašu, kad kone $18 \mathrm{~m}$ pločio fasade jų galèjo būti ir daugiau. Rūmai buvo trijų aukštų su trikampiu šiaurès renesansui būdingų formų atiku [9 il.]. Kasinėjimų metu rasta daug ìvairiomis glazūromis nuspalvintų koklių ${ }^{11}$.

Vartai ir tiltas. $1625 \mathrm{~m}$ plane ir graviūroje rytiniame pilies kiemo pakraštyje pavaizduotas vartų bokštas su i ji iš kitos fosos pusės nutiestu tiltu [10 il.]. Vartų pastatas stovèjo ant pili juosiančio kiauto krašto. Bokšto pietinejje sienoje pavaizduota vartų anga, o virš jos, antrame aukšte - trys langai ar šaudymo angos. Vartų pastatą vėliau išplètė Boguslavo Radvilos statybininkai. Kažkokie darbai buvo vykdyti ir anksčiau, Jonušo Radvilos statybų laikotarpiu. Iš istorikų surinktų dokumentų ir archeologinių tyrimų matyti, kad Kristupo I Radvilos statytų vartų mūrai buvo iki 1704 m. stovejusių vartų centre. Nuo pat pirmosios pilies statybos išstovejjusios vartų pagrindinio tūrio sienos èmè nykti po 1704 metų. Prieš pradedant

10 Valdas Rakutis, „Biržų tvirtovès karinè reikšmė ir efektyvumas“, in: Biržų istorijos apybraižos, Vilnius: Danielius, 2006, p. 49-63.

11 Roma Songailaitè, Tatjana Niedvarienè, op. cit., p. 24-36. 


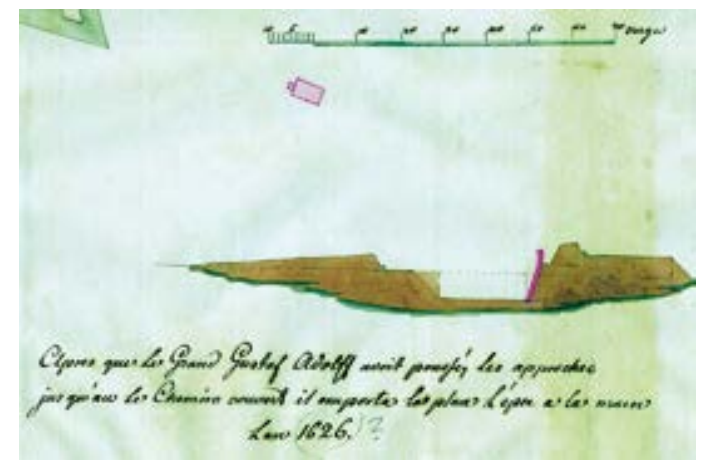

5.

Pjūvis per fosą švedų $1625 \mathrm{~m}$. sudarytame tvirtovès plane. Mūrinis kiautas pažymètas rausva spalva

Cross-section at the moat in the Swedish plan of 1625 . The brick shell is marked in pink

archeologinius vartų ploto tyrimus čia stūksojo nedidelè, krūmais apaugusi, mažai besiskirianti nuo pylimų kalvelè. Natūroje liko pamatai ir keletas virš žemės paviršaus iškilusių mūrų fragmentų.

Pastato pamatus ir dalį sienų 1963 m. užčiuopè architektas Algimantas Urbštas ${ }^{12}$. 1963-1965 m. vartų plote ir pilies mūrinio kiauto zonoje toliau kasinejjo archeologas K. Mekas. Daugiausia medžiagos davė $1964 \mathrm{~m}$. tyrimai. 1965 m. architektas Stanislovas Mikulionis su techniku apmatuotoju A. Šližiu apmatavo vartų mūrų liekanas ${ }^{13}$, nubraižè jų planą. Po $1965 \mathrm{~m}$. vartų mūrai netyrinèti. Detalesnių šių mūrų tyrimų ataskaitų ar jų raidos (stilistinių) kartogramų nerasta. Apie 1975 m. pagal K. Meko 1963-1965 m. tyrimų duomenis buvo sudaryta Biržų pilies tilto ir vartų pastato raidos kartograma ${ }^{14}$ [11 il.]. Vartų struktūra ir raida aprašyti daugiausia remiantis K. Meko tyrimų išvadomis ${ }^{15}$, taip pat minètais S. Pinkaus aprašymais. Vadovaujantis Meko aprašymais ir Mikulionio bei Šližio apmatavimais, $1993 \mathrm{~m}$. nubraižyta vartų žemutinio aukšto plano schema ${ }^{16}$.

Vartų pastatas buvo dviejų aukštų, su šaudymo angomis, uždengtas keturšlaičiu stogu su špiliumi [žr. 3 il.]. Vartus iš rytų ir šiaurès formuojančios sienos buvo atviros, be žemès pylimų, kilo nuo pat fosos apačios.

12 Algimantas Urbštas, Buv. Radvilų pilis Biržuose, Tyrimai natūroje, t. IV-VIII, 1961, in: Vilniaus regiono valstybès archyvas (toliau - VRVA), f. 5, b. 73, 75a, 75, 93, 96, 98.

13 Brèžinių Vilniaus regiono valstybès archyve, kuriame saugomas Paminklų restauravimo instituto fondas, nerasta.

14 Napalys Kitkauskas, op. cit., p. 136-156; Karolis Mekas, Biržų pilis (1963 m. spaliolapkričio mèn. tyrimų ataskaita), in: VRVA, f. 5-206.

15 Karolis Mekas, Biržų pilis (1963 m. spalio-lapkričio mèn. tyrimų ataskaita), in: VRVA, f. 5-206; Idem, Biržų pilies tyrimas, 1964, in: VRVA, f. 5-185; Idem, Biržų pilies tyrimas, 1965, in: VRVA, f. 5-227; Idem, „Biržai“, in: Mokslas ir gyvenimas, 1966, Nr. 7, p. 30-33.

16 Evaldas Purlys, Biržų pilis: pilies pastatai kieme archeologinių tyrimų duomenimis, 1993, in: VRVA, f. 5-5635. 
Sienos plokštuma kiek pasvirusi. Paviršius formuotas iš stambių gotikiniu būdu rištų plytų. Vakarinè vartų siena buvo 7,8 m nuo rytinès. Taip pat, kaip rytinė vartų siena, buvo formuota fosos siena vakarinės vartų sienos tęsinyje, kilo nuo fosos apačios. Šios sienos liekanos surastos $4 \mathrm{~m}$ gylyje nuo didžiojo pylimo paviršiaus. Vakarinès vartų sienos storis - 1,7 m, rytinės 2,5 m. Kasinèjimų metu surastos kelios šaudymo angos.

I pili buvo patenkama per tarp šių dviejų prasilenkiančių sienų įkomponuotą vartų pastatą. I šiaurinį vartų pastato galą rėmėsi per fosą pastatytas medinis, kreivas, greičiausiai ant medinių stulpų tiltas. I vartus ir toliau i pilies kiemą buvo galima patekti tik pervažiavus tiltą per fosą. Apie galimai ant tilto buvusius vartus žinių neturime. Gynybos sumetimais vartų angos išdèstytos ne vienoje ašyje. Angų plotis - 2,9-3,0 m. Vartų bokštas buvo 19,5 m ilgio išorejje, 15,3 m viduje. Bokšto plotis išorėje - 11,7 m, viduje $-7,8 \mathrm{~m}$. Stovejjo jis išilgai rytinio pylimo. Šiaurinèje pastato sienoje likusios vartų angą formavusių mūrų liekanos - angokraščių mūro fragmentai, staktų atspaudai juose. Vartų angos apačia buvo apie $4 \mathrm{~m}$ nuo fosos dugno. Išliko ir pietinès vartų angos liekanos. Pietinės angos šone buvo atkastas iš dolomito iškaltas staktos fragmentas.

Graviūroje, deja, matomas tik pietinis vartų fasadas su centre pavaizduota pietine vartų anga - ši anga, kaip rodo kasinejjimų duomenys, turèjo būti kairiau, beveik prie pat kampo. Graviūroje pavaizduota prie pietinio vartų kampo prigludusi sienutè užfiksuota kasinėjimų metu, tačiau ne pavaizduotoje vietoje, o dešiniau vartų angos. Iš kasinėjimų metu atidengtų pirmosios pilies rytinès kraštinès mūrų aprašymo galima suprasti, kad ir kazematų pastatas rytiniame bastione, prie šiaurès rytų pilies kraštinès, graviūroje pavaizduotas ne visai tiksliai [žr. skirsnị apie kazematus].

Kazematai. 1625 m. plane ir T. Makovskio graviūroje pavaizduoti 8 kazematai, ịkomponuoti bastionų kakleliuose po vieną kiekvienoje pusèje. Iš jų kryžmine ugnimi buvo apšaudomas iki pylimų prasibrovęs priešas. K. Mekas užčiuopè šiaurinio ir pietinio kazematų, stovejjusių prie rytinès pilies kraštinès, liekanas. Pasimatè kai kurie kazematų architektūros elementai, sužinotas šiaurinių [paryškinta, $-E$. $P$.] kazematų fasado plotis (5,45 m). Šalia atsidengè šiaurinio bastiono rytinis apvalusis apmūrytas

$97-2020$

Acta Academiae Artium Vilnensis 


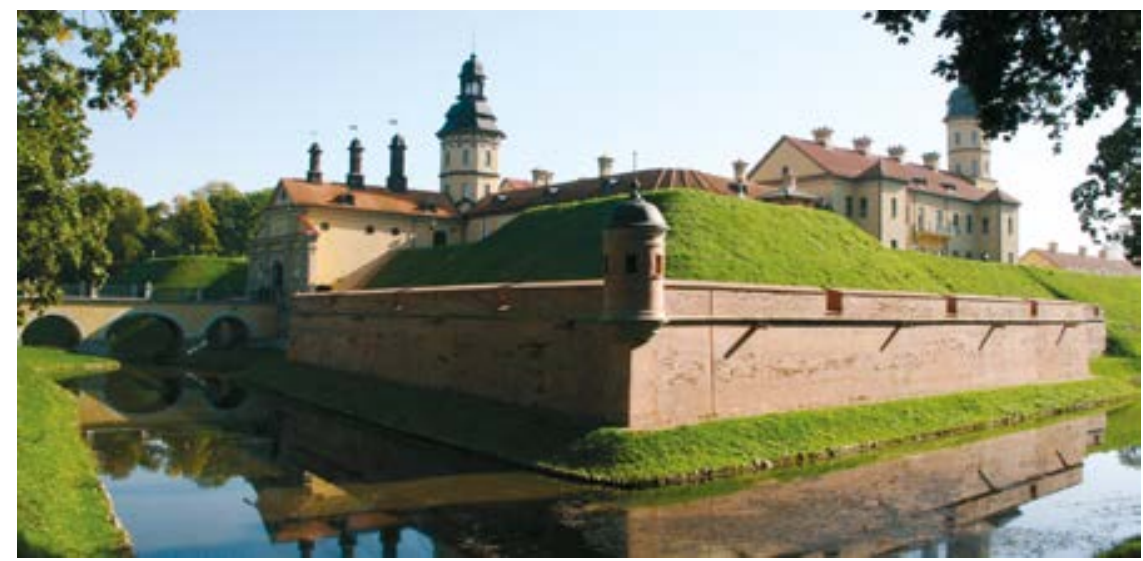

6.

Atidengtas ir iš dalies restauruotas Nesvyžiaus

Exposed and partially restored fragment of the first pirmosios pilies fragmentas, 2014, nežinomo autoriaus nuotrauka

Nesvizh castle

kampas. Antrame pastato aukšte išliko dviejų šaudymo angų apačios. Šaudymo angos čia buvo „X“ formos, 1,15 m ir 1,18 m pločio. Fasadinè siena pirmo aukšto lygyje - 2,3 m storio, čia rastos dvi ovalo formos šaudymo angos. Beveik visą pastato kontūrą po 4,5 m storio sluoksniu dengia didysis Kristupo II Radvilos pilies pylimas, kazemato vidus užverstas griuvenomis, todèl liko nenustatytas pastato plotis, perdangos lygis ir tipas, ryšio su pilies kiemu vieta ir pan. Atrodo, šio kazematų pastato žemutiniame aukšte (kaip pavaizduota ir graviūroje) [12 il.] nebuvo vartų angos iš fosos kaip kazematų pastate pietiniame rytinės pilies kraštinès gale.

Mūrinio kiauto 44,5 m atkarpa nuo posūkio su įvažiavimo vartų anga pietiniame gale (ị kairę nuo vartų) stačiu kampu pasuka ị rytus, formuoja pietinių [paryškinta, $-E$. P.] šioje kraštinëje kazematų priekini fasa$\mathrm{dą}^{17}$. Iš atkastų mūro fragmentų nustatyti pastato dydị ir daugiau architektūrinių elementų jo sienose nepavyko. Sienų likučiai vietomis kyla apie $5 \mathrm{~m}$. Kitų ikonografijoje pavaizduotų kazematų neieškota. Gaila, atkasti mūrai fiksuoti tik nuotraukose ir aprašymuose. Nepavyko rasti apmatavimų brèžinių, todèl ne visada aišku, kurioje konkrečioje vietoje konkretūs aprašyti elementai. Vienas tokių elementų - 2,8 m aukščio ir 2,68 m pločio arka, per kurią buvo patenkama ị kazematą. Atrodo, ji yra graviūroje pavaizduoto 


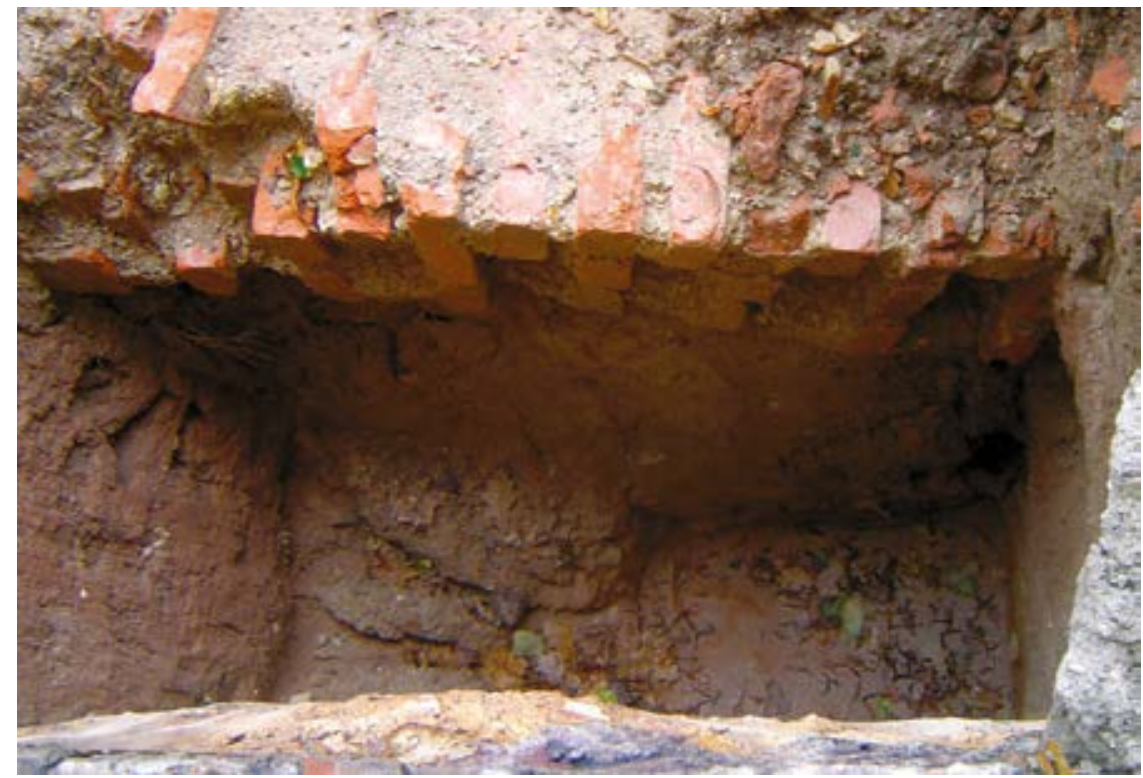

7.

Kristupo I Radvilos rūmų vidurinès išilginès sienos arkinio pamato fragmentas, Evaldo Purlio nuotrauka, 2007

Detail of the arch foundation of the middle longitudinal wall of Krzysztof I Radziwiłł's palace

kazematu pastato nematomoje pusejje, nuo fosos dugno kylančio fasado apačioje. Taip ịkomponuota vartų (?) anga pavaizduota vakarinio bastiono pietvakarių kazematų pastate. Virš angos trys šaudymo (?) angos [žr. 9 il.].

Sugretinę nors ir labai fragmentiškus kasinèjimų metu sukauptus duomenis apie kazematų, vartų bei išorinio kiauto architektūrą su graviūroje užfiksuotais jų vaizdais, matome, kad graviūra, nežiūrint schematiškumo, gana patikimai fiksuoja anuo metu funkcionavusius kazematu (greičiausiai ir kitų pastatų) architektūrinius elementus. Kazematai, sprendžiant iš T. Makovskio graviūros, dviejų ar trijų aukštų, su pastatų viršuje visą perimetrą supančiais atikais (?) ir durų angomis [kiemo lygyje, - E. P.] viename iš fasadų [žr. 9 il.]. Vaizduodamas mūrinị kiautą natūroje kiautu taip ir nesutvirtintas pilies kraštines, taip pat pilies statinius T. Makovskis greičiausia naudojosi anuo metu dar turètais projektais, piešiniais. 
Parakinès. Natūroje nė vienos parakinès plote nekasinèta. Parakinių vaizdą, planą ir kompoziciją kol kas galime ịsivaizduoti tik iš vaizdo graviūroje. Parakinès buvo pusiau požeminès, irengtos kiekviename bastione [žr. 3,12 il.]. I jas buvo įeinama per nedidelius pastatèlius, už kurių iki pat bastionų galų, atrodo, tęsėsi požeminè parakinių dalis su bastionų galuose iškylančiais apvaliais ventiliacijos (?) bokšteliais.

Arsenalas. Pirmosios žinios apie Biržų arsenalo statybas siekia $1612 \mathrm{~m}$., atrodo, tuomet jis buvo perstatomas. Naujasis pastatas planuotas siauresnis (12 lietuviškų uolekčių vietoj 15,5), bet dvigubai ilgesnis (83 uolektys vietoj 40) ir turèjo išsidėstyti tarp pilies bokštų. Dvariškis Kristupas Skulimovskis K. Radvilai siūlė 52 uolekčių ilgo pastatą su vartais abiejuose arsenalo galuose - baimintasi, kad kilus gaisrui iš labai ilgos patalpos būtų sudètinga išgabenti inventorių. Arsenalo konstrukcijoms naudota ą̌uolų ir kẻnių mediena. 1613 m. jis jau turèjo būti pabaigtas, nes žinoma, kad pastate buvo išdèliota ir parengta amunicija ${ }^{18}$.

Bažnyčia. T. Makovskio graviūroje pavaizduota nemažai statinių, išdèstytų bastionuose ir šalia jų, pilies kiemo pakraščiuose. Visi jie išnyko kartu su pirmaja pilimi. Ryškiausias statinys pilies kieme - bažnyčia. Kažkodèl ji buvo ịkomponuota labai arti rūmų pagrindinio fasado. Kasinèjimų metu kol kas nerasta nė fragmento jos pamatų, nežinia, iš kokių medžiagų ji buvo pastatyta. Greičiausia buvo mūrinė arba fachverkinė, nes XVII a. antroje pusejje jos varpinė ardyta plytoms. Dalis bažnyčios pamatų galèjo būti išardyta Jonušui Radvilai pradėjus rūmų su plačiais išoriniais laiptais statybą. Pamatai, ypač jei bažnyčia buvo medinè, galèjo būti apardyti ir klojant grindinį, èjusį nuo išorinių laiptų. Dalis pamatų likučių po šiuo grindiniu galëjo būti sunaikinta tiesiant inžinerines komunikacijas 1978-1986 metais. Galima tikètis tik nedideliu bažnyčios priekinès dalies pamato fragmentų.

Kiti statiniai pilies kieme. Graviūroje matome bokštelius smailiuosiuose bastionų kampuose ir šoniniu pylimų centruose. Jie pažymèti ir $1625 \mathrm{~m}$. plane. Nė vieno iš jų likučių kol kas nerasta.

1960-1963 m. archeologiniu tyrimų ataskaitose fiksuoti atkasti kelių nedidelių statinių, stovejjusių plote tarp vakarinio bastiono ir rūmų šiaurès vakarinio galo, pamatų fragmentai. Dalis jų galèjo būti laikini statybinių 
medžiagų sandėliavimui ar paruošimui skirti pastatai. 2015 m. archeologè R. Songailaitė užčiuopė vadinamosios antrosios pilies pylimais uždengtus Kristupo I Radvilos pilies statinių mūrų fragmentus. Norint išsiaiškinti juc kontūrus, reikètų didelès apimties kasinėjimų ardant autentiškus antrosios pilies pylimus. İvairiu laiku atkastus pamatų fragmentus archeologè pažymèjo pilies plane [žr. 2 il.].

\section{Kristupo II Radvilos pilies statybų etapas}

Remiantis S. Pinkaus tyrimais, žinoma, kad 1626 m., po 1625 m. sugriovimų atgavęs Biržus, Kristupas II Radvila atstatinėjo (tiksliau, perstatinèjo) apgriautą pili iki pat mirties 1640 metų. Tą darė jau vadovaudamasis olandų bastioninių pilių tradicija. Pilies rekonstrukcijos brèžinius parengė inžinierius, karinis architektas Georgas Pirkas. Esminiai pertvarkymai vyko 1637-1639 m. ir su pertraukomis iki pat 1655 metų. Nugriauti visi pirmosios pilies pastatai, ardytas ar užpiltas mūrinis senosios pilies pylimų kiautas. Daugeli nugriautų statinių liekanų, taip pat Kristupo I Radvilos pilies pylimų mūrinị kiautą uždengè paaukštintų naujujų pylimų gruntas. Naujasis pylimas ėmè dengti ir du kieme esančius šulinius, todėl reikėjo pakelti ju rentinius ${ }^{19}$. Šie ir galimai iškasti nauji šuliniai dar nesurasti. Pirmosios pilies šuliniai, nors atsidūrè naujai supilto pylimo šlaite, atrodo, buvo naudojami ir perstačius pilį.

Senosios pilies virsmą olandiškos fortifikacinès sistemos pilimi 1637-1639 m. atskleidžia Biržų statybos knyga ${ }^{20}$. Pasak S. Pinkaus, rūmus ir kitus pastatus norèta pradèti po to, kai bus baigta velènuoti pylimus, t. y. 1636 metais. Perstatyta nauja bastioninė olandiško tipo Biržų pilis vėl tapo gynybai tinkama tvirtove ${ }^{21}$ (pylimai tvirtinti ir velènuoti dar ir $1640 \mathrm{~m}$.). Paskutiniame etape buvo baigta pilti bolverkas nuo upės pusès ir tvirtinta fosa iš abiejų vartų pusių. Fosa tvirtinta tik praplatinus ir pagilinus griovị, siekiant išvengti, kad sraunus vanduo atidarius užtvanką neapardytų fosos kaip būdavo anksčiau ${ }^{22}$.

19 Stasys Pinkus, op. cit., 1986, p. 19.

20 Biržu pilies statybos 163\%-1638 m. dokumentu kopiju knyga-Ksiega budowy Birź (KBB). Saugoma Radvilų archyve Varšuvoje (AR dz. IVa, ks. 1b). Tai speciali Biržų kunigaikščio dvaro raštinėje vesta dokumentų (korespondencija, instrukcijos, inventoriai) nuorašų knyga.

21 Stasys Pinkus, op. cit., 1986, p. 22.

22 Deimantas Karvelis, Biržų pilies komplekso istoriniai tyrimai, p. 51. 
Pirmosios pilies rümu plano rekonstrukcija pagal 1989 ir $1991 \mathrm{~m}$. tyrinęimų rezultatus

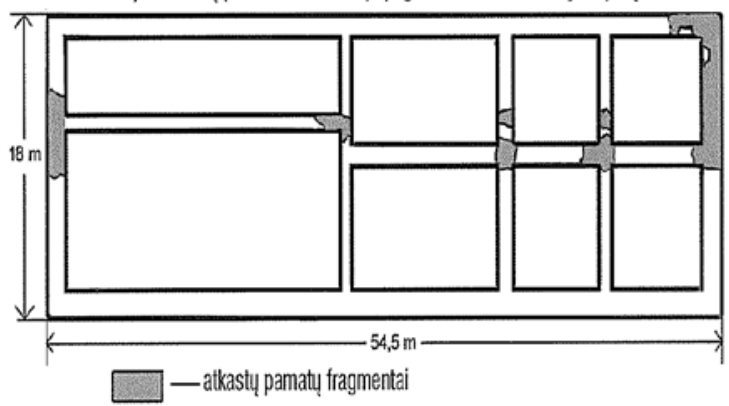

8.

Kristupo I Radvilos rūmų plano rekonstrukcija pagal 1989 m. ir 1991 m. tyrinèjimu rezultatus, sud. Jonas Genys, in: Lietuvos piliu archeologija, Klaipėda, 2001, p. 211

Reconstruction of Krzysztof I Radziwiłł's palace plan according to the research of 1989 and 1991

$\boldsymbol{R} \bar{u} m a i$. Naujoji pastatų pilies kieme išdèstymo schema turèjo būti sumanyta jau planuojant pilies rekonstrukcijos darbus, projektuojant naujoviškus olandiško tipo fortifikacinius įrengimus, apsisprendus iki pamatu nugriauti senuosius rūmus ir kitus pastatus. Darbai negalèjo būti pradèti be viso komplekso pertvarkymo projekto. Iki tol imtasi statyti medinius rūmus netoli pilies buvusiame palivarke. $1631 \mathrm{~m}$. medinis Kristupo II rūmas jau buvo baigiamas statyti' ${ }^{23}$. Kurị laiką vyko rūmų pilies kieme architektūrinio sprendimo paieškos.

Po apsilankymo Biržuose $1637 \mathrm{~m}$. rugpjūčio $3 \mathrm{~d}$. - rugsejjo $8 \mathrm{~d}$. Kristupas II Radvila parašè, kad norètų pilies kiemo vidury pastatyti ittvirtintus rūmus (vad. kastelę). Atsiuntè net to pastato eskizą. Ieškojo architekto, kad šis padarytų pastato brèžinius. Iš pradžių galvota statyti pagal 1619-1620 m. iškilusių Zigmanto Vazos rūmų Ujazdove (Lenkijoje) pavyz$\mathrm{dị}^{24}$. Planuota, kad rūmai bus mūriniai, dviaukščiai su kvadratiniu kiemu bei šešiakampiais bokštais kampuose. Kitų numatomų statinių sąraše įvardyti svirnas, arsenalas didelèms patrankoms bei kitai amunicijai, parako rūsiai, lobyno rūsys, kareivinès, arklidès, pilies amatininkų namai, bravoras, pirtis, kalvè. Planuota įrengti šulinius. Norèta, kad rūmuose būtų koplyčia, kunigaikščio, kunigaikštienès, moterų kambariai, valgomasis, virtuvė, kepykla, maisto kamaros, menės svečiams ir kt. ${ }^{25}$

Tačiau šiame etape naujosios pilies rūmų pastatas nebuvo pradètas statyti. Pirmiausia imtasi pilies funkcionavimui taip reikalingu ịvairios

23 Stasys Pinkus, op. cit., 1971, p. 254.

24 Stasys Pinkus, op. cit., 1986, p. 21-22; Deimantas Karvelis, Biržų pilies komplekso istoriniai tyrimai, p. 48.

25 Stasys Pinkus, op. cit., 1986, p. 21. 


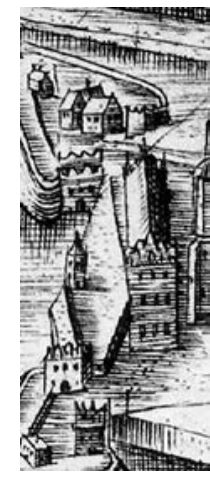

\section{9.}

Kristupo I Radvilos pilies rūmai Tomo Makovskio graviūroje. Už jų vakarinis bastionas su dviem kazematais, parakine ir kitais statiniais. Pietinių šio bastiono kazematų priekinis fasadas kyla nuo fosos apačios. Fasado apačioje vartų anga. Natūroje tokia anga užčiuopta tik kylančiame nuo fosos apačios rytinio bastiono šiauriniu kazematų fasade. Priekiniame nuotraukos plane pietinio bastiono kazematai

Krzysztof I Radziwiłł's palace in T. Makowski's engraving. Behind it is the western bastion with two casemates, a powder house and other buildings

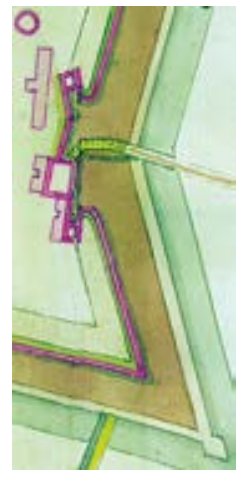

10.

Kristupo I Radvilos pilies vartai ir tiltas $1625 \mathrm{~m}$. švedų sudarytame Biržų tvirtovès ir miesto gynybinių itvirtinimu plane. 1963-1965 m. tyrinèta atkarpa tarp kazematu, kazematų priekinès sienos

Gate and bridge of Krzysztof I Radziwił’'s castle in the Swedish plan of the Biržai fortress and the city's fortifications of 1625 . In 1963-1965, the segment between the casemates and the front wall of the casemates was explored

paskirties ūkinių (galbūt ir laikinų) pastatų. Atrodo, dauguma jų buvo mediniai ar fachverkiniai. Spèta iš dalies atstatyti vartų pastatą, senąsias arklides pertvarkyti ị laikiną arsenalą.

Arsenalas. 1637 m. restauruojant pilị su vokiečiu staliumi Jokūbu Šidaku sudaryta atskira sutartis dèl arsenalo remonto. Joje numatyta, kad dalis pilies arklidžių bus pritaikyta šiai paskirčiai. Stalius turèjo išlyginti ịlinkusias ąžuolines arklidès sienas, po stogu ịrengti dvi užrakinamas ir saugias slèptuves, pataisyti langus. Valstiečiai, talkininkavę staliui, turèjo išlyginti naujojo arsenalo grindinị. Dažytojas ne tik patị arsenalą, bet ir patrankas nudažè juodai ${ }^{26}$. Siekta, kad arsenalas, kaip ir visi kiti pilies rūmų pastatai, būtų ne tik erdvus, bet ir proporcingai išdèstytas, netrukdytų nei gyvenantiems, nei tarnaujantiems pilyje $\mathrm{e}^{27} .1637 \mathrm{~m}$. planuota šalia pylimo esančias mūrines vynines paversti parako laikymo patalpomis, iš viršaus jas apsaugojus nuo drègmės ir įstačius geležines duris. Vèliau parako sandėlys, kuriame buvo laikomi ir rankiniai šaunamieji ginklai, įrengtas vartų pastate $^{28}$. Pats arsenalas, $1637-1639 \mathrm{~m}$. restauruojant pili, tarnavo kaip darbo irrankių ir kitos įrangos sandèliavimo vieta.

26 Deimantas Karvelis, Biržų pilies komplekso istoriniai tyrimai, 2008, VI „Lietuvos paminklai“ autorinių darbų saugykla, Evaldo Purlio asmeninis archyvas, p. 94. 
Vartai ir tiltas. Vienintelis kelias patekti ị pili vedè per pilies tiltą - vienoks ar kitoks tiltas (laikinas ar stacionarus) turèjo būti vienas pirmụu pertvarkomos pilies statinių. Medieną tiltui imta ruošti 1637 metais. Istorikų tyrinèti dokumentai suteikia žinių apie projektavimo darbų pradžią 1637 m. ir vartų statybu planus. Kristupas II Radvila verkmeisteriui ir architektui J. Armandui pavedè apžiūrèti vartų pastatą ir nutarti, ar jị palikti. Taip pat ịsakè nutiesti naują įvažiavimą pro vartus ị pilįi29. Neužilgo Radvila architektui A. Jostui nurodè parengti pilies vartų ir tilto perstatymo projektą ${ }^{30}$.

Didžiausi vartų pastato plano struktūros pakeitimai susiję su tilto kryptimi ir architektūra. Pakeitus įvažiavimo per vartus vietą, tiltas nukreiptas jau ne ị šiaurinę, o ị rytinę vartų pastato sieną, kurioje naujo tilto išilginès ašies kryptimi iškirsta vartų anga. Senosios šiaurinejje ir pietinëje vartų pastato sienose buvusios vartų angos užmūrytos. Archeologinių tyrimų metu rastos senujjų vartų angų angokraščių liekanos.

$1637 \mathrm{~m}$. žiemą nutarta, kad pylimą, priešpylimị reikia daryti aukštesnius ir platesnius nei iki tol. Manyta, jog tokiu būdu pilies vartų pastatas taps tarsi įmūrytas ị pylimą ir taip sutvirtintas. Tik taip galima buvo išsaugoti bent vieną senajji Kristupo I Radvilos atminimą menantị pastatą ${ }^{31}$. Kaip liudija dokumentai, reikejjo sustiprinti pastato sienas, kad daugiau neskilinètų, užtaisyti plyšius, ištinkuoti vidų ir išorę, pataisyti stogą, suremontuoti laiptines, atnaujinti jose buvusi dekorą, pagaminti naujus ąžuolinius langu rẻmus, dažytojui visas raides atnaujinti, visą pastatą kuo gražiau išpuošti meniškomis lubomis, grindimis, paveikslais, nes jis numatytas kunigaikščiui apsistoti. Visa tai padaryta iki $1640 \mathrm{~m}^{32}$

Vartų pastatas turejjo būti statomas iš stambių akmens luitų, kad būtų atsparus artilerijos ugniai. Luitus planuota sutvirtinti geležinèmis sankabomis. Vèliau planuota visą pastatą apkalti skarda. Pastate planuota ịrengti parakinę bei ginklų saugojimo kambarị, skirtą greičiausia sargybai. Geležinès vartų durys turèjo būti panašios ị Vilniaus evangelikų bažnyčios duris. Virš vartų turẻjo būti dvi iš užsienietiško marmuro padarytos plokštès su Kristupo II Radvilos užrašu ir Radvilų giminès herbu ${ }^{33}$.

29 Stasys Pinkus, op. cit., 1986, p. 19.

30 Deimantas Karvelis, Biržų pilies komplekso istoriniai tyrimai, p. 50.

31 Ibid.

32 Stasys Pinkus, op. cit., 1986, p. 19.

33 Deimantas Karvelis, Biržų pilies komplekso istoriniai tyrimai, p. 51. 
Iki $1640 \mathrm{~m}$. tiltas dar nebuvo pastatytas. Iki to laiko ì pilies kiemą, matyt, buvo važiuojama laikinu mediniu tiltu. Kad tilto atramos nepūtu, 1640 m. balandžio 3 d. laiške Biržų seniūnas J. Penkalskis pasiūlė Radvilai jas daryti mūrines - tokias jis matęs Vokietijoje, kur ant įleistų i vandeni mūrinių stulpų uždèti didžiuliai ąžuoliniai balkiai ir tik tada medinès tilto konstrukcijos ${ }^{34}$.

Pirmasis naujas tiltas galëjo būti pastatytas iškart ant mūrinių atramų. Galimai medinių naujojo tilto atramų nerasta ar neliko ruošiant masyvius mūrinių tilto atramų pamatus. Vèliau ne kartą atramos remontuotos, ne kartą buvo keičiama medinė tilto dalis. Duomenų, kad būtų keičiamas mūrinių stulpų išdèstymas, nerasta.

1640 m. Kristupas II Radvila mirè, jo pradètus darbus perėmè sūnus Jonušas Radvila.

\section{Jonušo Radvilos statybos pilyje}

Jonušas Radvila, kuris sprendžiant iš pradètų statyti rūmų dydžio ir kapitalumo, energingai ėmėsi pilies statybų. Atsisakyta ketinimų pilyje statyti įtvirtintus rūmus (kastelę). Naujiems rūmams projektuoti pakviestas Jonas Ulrichas, o fortifikavimo statyboms - Adomas Freitagas. Gali būti, kad magistras J. Ulrichas paruoše ir visą pilies kiemo statinių perstatymo schemą. Naujo kapitalaus rūmų pastato statyba negalèjo būti pradèta neturint bent jau aiškios būtiniausių pilies funkcionavimui pastatų komponavimo pilies kieme vizijos. Deja, išvykos ị karo veiksmų vietas, politinė veikla labai trukdè normaliam statybų darbui, o prasidejjusios kovos su švedais ir Maskva bei fundatoriaus mirtis $1655 \mathrm{~m}$. pradètus darbus paliko nė neipusètus. Apie Jonušo Radvilos statybų laikotarpio pastatus turime nedaug žinių, galime trumpai užsiminti apie vartus ir tiltą bei rūmų statybų pradžią.

Vartai ir tiltas. Vartų pastatas užbaigtas ar beveik užbaigtas iki 1640 metų. Pasikeitus šeimininkui, norèta, kad tai matytųsi ir ịvažiuojant i pili. Jau $1640 \mathrm{~m}$. Biržuose dirbo jo iš Rygos pakviestas dailininkas, puošęs pilies vartus akmenyje iškaltu Jonušo Radvilos atvaizdu ${ }^{35}$. Iki 1655 m. tikriausiai buvo naudojamasi prieš keliolika metų pastatytu tiltu. Tilto struktūra, vartų ant tilto išdėstymas buvo užprogramuoti projektuojant ir 


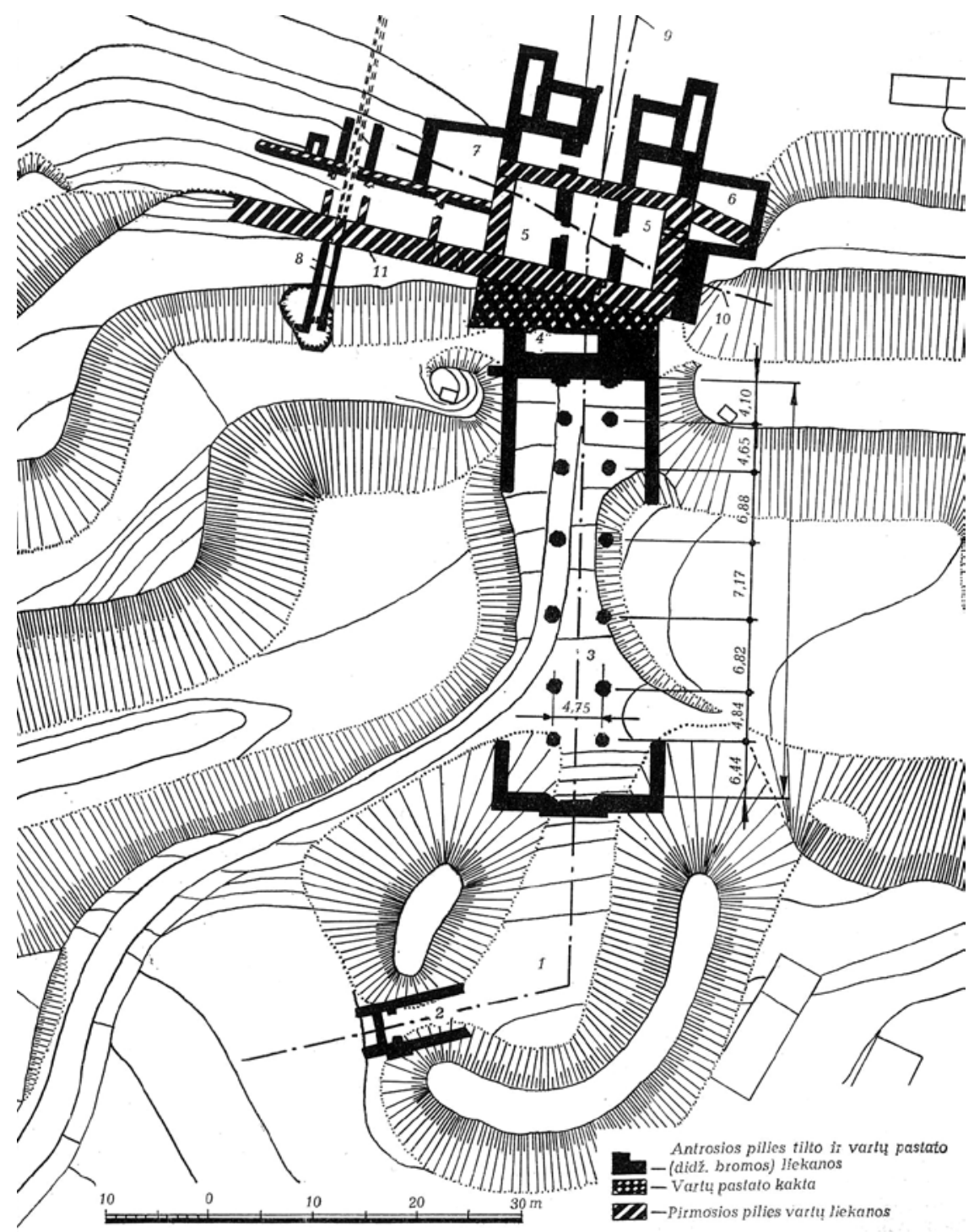

11.

Pilies vartu raidos kartograma. Kristupo I Radvilos pilies vartų kontūre pažymèta važiavimo per ne vienoje ašyje išdèstytas vartų angas linija. Kartogramoje vaizduojamas jau pertvarkytas tiltas. Senosios ir naujosios vartu angos nepavaizduotos, in: Architektūros paminklai, t. 3, 1975, Vilnius: Mokslas, p. 145
Cartogram of the development of the castle gate. In the contour of Krzysztof I Radziwił’'s castle gate, the line of passing through the gate openings arranged on a different axis is marked

Evaldas Purlys

Biržu pilies statinių architektūra ir jos raida 
statant mūrines tilto atramas. Ano meto tvirtovèse ant tilto per fosą turèdavo būti bent du keltuvai ir vieni uždaromi vartai be keltuvo ${ }^{36}$. Seniausias, išsamiausias tilto ir vartų ant jo aprašymas užfiksuotas Biržų pilies $1674 \mathrm{~m}$. inventoriuje $\mathrm{e}^{37}$. Atramos buvo remontuotos ${ }^{38}$, tačiau jų vieta nuo pat pirmujuc mūrinių atramų statybos nebuvo keičiama.

Rūmai. Jonušo Radvilos valdymo laikotarpiu rūmai buvo suprojektuoti ir pradèti statyti. S. Pinkus, remdamasis D. Kosciuškos $1662 \mathrm{~m}$. kovo 2 ir 23 d. laiškais B. Radvilai, magistro J. Ulricho sudarytu metalo dirbinių sąrašu, prièjo išvadą, kad pastarasis buvo ne tik rūmų mūrų sutvirtinimų žinovas, bet ir pastato projekto autorius ${ }^{39}$. Tai įrodo $1662 \mathrm{~m}$. Boguslavo Radvilos laiškas, kuriame sakoma, kad jis turi Jonušo Radvilos laikais darytus rūmų brèžinių originalus ${ }^{40}$.

Biržų pilies naujujų rūmų statyba J. Radvila pradèjo rūpintis 1649 m. ${ }^{41}$ Tačiau turimi dokumentai nerodo tikslios rūmų statybos pradžios, nepaaiškina, kaip vyko statyba ir kiek buvo pastatyta. Visgi aišku, kad iki 1655 m. buvo išmūryta nemaža dalis rūmų pastato sienų. Kokio aukščio ir kaip turèjo atrodyti J. Ulricho projektuoti rūmai, galima spręsti remiantis informacija anuo metu mūrytose sienose ir užuominomis rašytuose laiškuose, B. Radvilai perėmus rūmų statybos rūpesčius. Kadangi žinios apie iki $1655 \mathrm{~m}$. padarytus darbus persipina su 1660-1669 m. darbais, skirsnị apie Jonušo Radvilos rūmus ir jų architektūrą ir kiek iki 1655 m. pakilo rūmų mūrai bandysime rekonstruoti aptardami jų statybas 1662-1669 m. laikotarpiu. Iš žinių apie J. Ulricho paliktus brèžinius ir jo projekto pakeitimus, iš to, kiek iki 1662 m. buvo pakilę sienų mūrai, pradès šiek tiek matytis ir J. Ulricho projektuotų rūmų vaizdas, architektūra. Naujieji rūmai ịkomponuoti prisiderinant prie naujosios, antrosios pilies pylimų ir pagrindinių naujosios pilies ašių, rūmai, kaip ir pylimai, pakreipti apie 5 laipsnius nuo senụjų rūmų pagrindinių krypčių ${ }^{42}$. Prieš $1655 \mathrm{~m}$. švedų antplūdį pilies šeimininkai gyveno mediniame pastate, kuris antpuolio metais buvo sudegintas ${ }^{43}$.

36 Napalys Kitkauskas, op. cit., p. 147.

$371674 \mathrm{~m}$. inventoriaus nuorašas saugomas KPC archyve, elektroninė inventoriaus kopija Biržų krašto muziejuje „Sèla“.

38 Karolis Mekas, Biržų pilies tyrimas, 1965, in: VRVA, f. 5-227, 1. 7-8.

39 Stasys Pinkus, op. cit., 1971, p. 263.

40 Deimantas Karvelis, op. cit., 2006, p. 19.

41 Stasys Pinkus, op. cit., 1971, p. 254.

42 Jonas Genys, Arūnas Baublys, op. cit., p. 206.

43 Stasys Pinkus, op. cit., 1971, p. 254. 


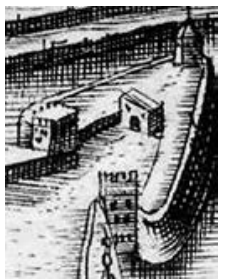

12.

Kristupo I Radvilos pilies šiaurinis bastionas Tomo Makovskio graviūroje. Abipus bastiono du kazematai. Virš šio ir kitų bastionụ kazematụ sienų atikai. Graviūroje pavaizduotuose atikuose galima įžiūrèti jų formavimui panaudotą ,kregždès uodegos" motyvą, dažnai naudotą italų Renesanso laikotarpiu. Bastiono kiemelio gale pavaizduotas įejimas ị parakinę

Northern bastion of Krzysztof I Radziwił’'s castle in T. Makowski’s engraving. There are two casemates on both sides of the bastion

\section{Boguslavo Radvilos statybų laikotarpis}

Atèmę iš švedų pili 1657 sausio 27 d., Gonsievskio kareiviai miestą nusiaubė ir sudegino ${ }^{44}$. Statybos dar keleriems metams sustojo. Tik $1659 \mathrm{~m}$. rugpjūčio $20 \mathrm{~d}$. i pilį ieejo $\mathrm{B}$. Radvilos žmonès. Imta ruošti statybines medžiagas, šiaudų stogeliais dangstyti prieš 9 metus pradètų statyti rūmų sienas, keisti supuvusius arsenalo sienų stulpus, remontuoti stogą. B. Radvila tvirtovės sutvarkymą laikè svarbesniu dalyku nei kitus ūkinius darbus ${ }^{45}$. Naują Biržų miesto ir pilies planą $1661 \mathrm{~m}$. Boguslavo Radvilos nurodymu parengè architektas Teofilis Spinovskis, vẻliau projektavęs ir pilies plane numatytus statinius. $1661 \mathrm{~m}$. lapkričio $10 \mathrm{~d}$. jis sudarè pilies, naujo miesto plano ir atskirą kareivinių brèžinį ${ }^{46}$. Architektas apmatavo pilies kiemą tarp pradètų statyti rūmų ir vartų, nurodè, kur turès būti kareiviniu pastatai. Apmatavo ir pradètus mūryti rūmus, padarė kareivinių planų ir fasadų brèžinius ${ }^{47}$, o pilies rūmų ir fasadų brèžinius pažadèjo atsiųsti vèliau ${ }^{48}$. Samueliui Arciševskiui Boguslavas Radvila pavedė vadovauti statyboms.

Pilies pastatai pagal iš anksto parengtą planą projektuoti ir statyti kuriant vieningą architektūrinị ansamblị su jame dominuojančiu rūmų tūriu ir didesniu nei kiti pastatai vartų tūriu. 1660-1669 m. statybų metu didžioji senuju pastatų dalis pakeista mūriniais, išdèstytais pagal naują (ar pakoreguotą?) generalini pilies projektą statiniais. Puošniausi meniniai akcentai buvo skirti rūmams ir vartų pastatui. Nemažai meno dirbinių planuota rūmų portalams. Pilies statinių išdèstymą po 1662-1669 m. ir galimai vẻliau, iki $1704 \mathrm{~m}$. vykusių statybu, atspindi $1704 \mathrm{~m}$. pilies planas [13 il.]. Archeologiniai tyrimai šį planą atskleidè natūroje ir šiek tiek patikslino. Surastos

44 Ibid., p. 258.

45 Deimantas Karvelis, Biržų pilies komplekso istoriniai tyrimai, byla LP-176(K-2008), 92 p., 2008, VI „Lietuvos paminklai“ informaciniai fondai; D. Kosciuškos 16591016 laiškas B. Radvilai.

46 Deimantas Karvelis, op. cit., 2006, p. 19.

47 Stasys Pinkus, op. cit., 1971, p. 262.

48 Stasys Pinkus, op. cit., 1986, p. 27. 


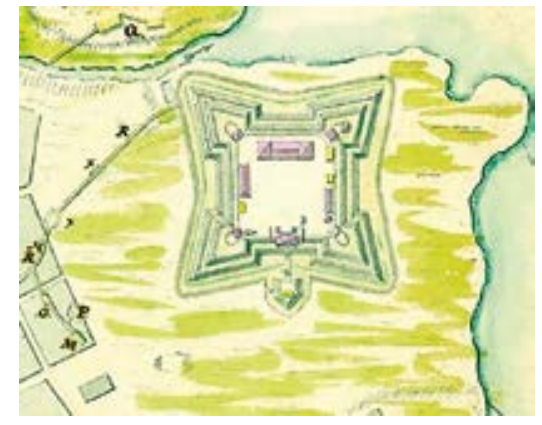

13.

Biržų pilies $1704 \mathrm{~m}$. planas

Plan of the Biržai castle of 1704

tuo metu statytų pastatų liekanos, daugiau ar mažiau išsiaiškinti daugelio iš šių pastatų planai, apdailos medžiagos ir net kai kurie mediniai elementai.

B. Radvilos statybu laikotarpio statiniai ir jų kompozicija pi-

lies kieme. Pilies gynybiniai pylimai [14 il.] griežtų geometrinių formų, turi aiškiai išreikštas išilginę, skersinę ir įstrižaines simetrijos ašis [15 il.]. Centre - stačiakampis pilies kiemas su kiemo pakraščiuose pilies funcionavimo metu buvusiais pastatais. Anksčiau statyti pastatai buvo griaunami, jų vietoje paamažu stojosi naujieji, daug kapitališkesni nei senieji pastatai. Visi B. Radvilos statybų laikotarpiu statyti pastatai mūriniai, sukomponuoti vadovaujantis aiškia pagrindinių pastatų išdėstymo pilies kieme schema. Iš pagrindinių pilies kieme komponuotų pastatų liko nepastatytas tik arklidžių pastatas.

Vienas charakteringiausių pilies statinių išdėstymo kieme bruožų - pastatų komponavimas pilies gynybinių pylimų kompozicijos ašyse, o jų architektūroje - fasadų simetriškumas. Kiemo gale išilginėje simetrijos ašyje stovi simetriškos architektūros rūmai, o ant ịvažiavimo ì rūmus vartų pastatas su beveik išilginėje pilies ašyje įkomponuota vartų anga. Pilies kiemo įstrižainėse bastionų kakleliuose įkomponuoti vienodo dydžio ir architektūros kareivinių pastatai, o bastionų galuose - vienodo dydžio parakinès. Laikantis simetrijos sukomponuoti kareivinių planai ir fasadai. Atrodo, siekiant kuo ryškiau pabrèžti rūmų ir visos pilies struktūros simetrijos ašị, rūmų pagrindiniame fasade ịkomponuotas lyginis arkų skaičius. Porinis vartų angų skaičius suprojektuotas ir arsenalo bei arklidžių pastatų 


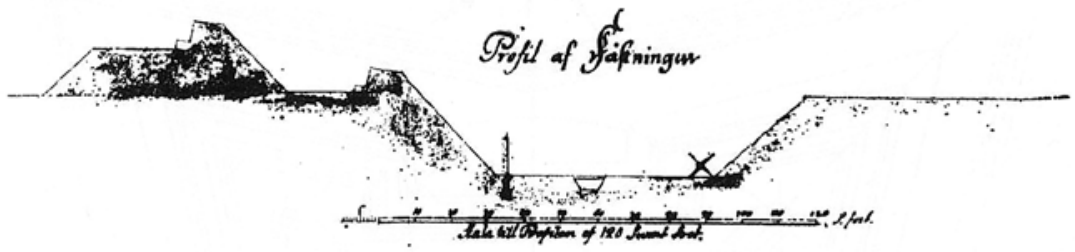

14.

Pjūvis iš $1704 \mathrm{~m}$. Biržų pilies plano

Cross-section of the plan of the Biržai castle of 1704

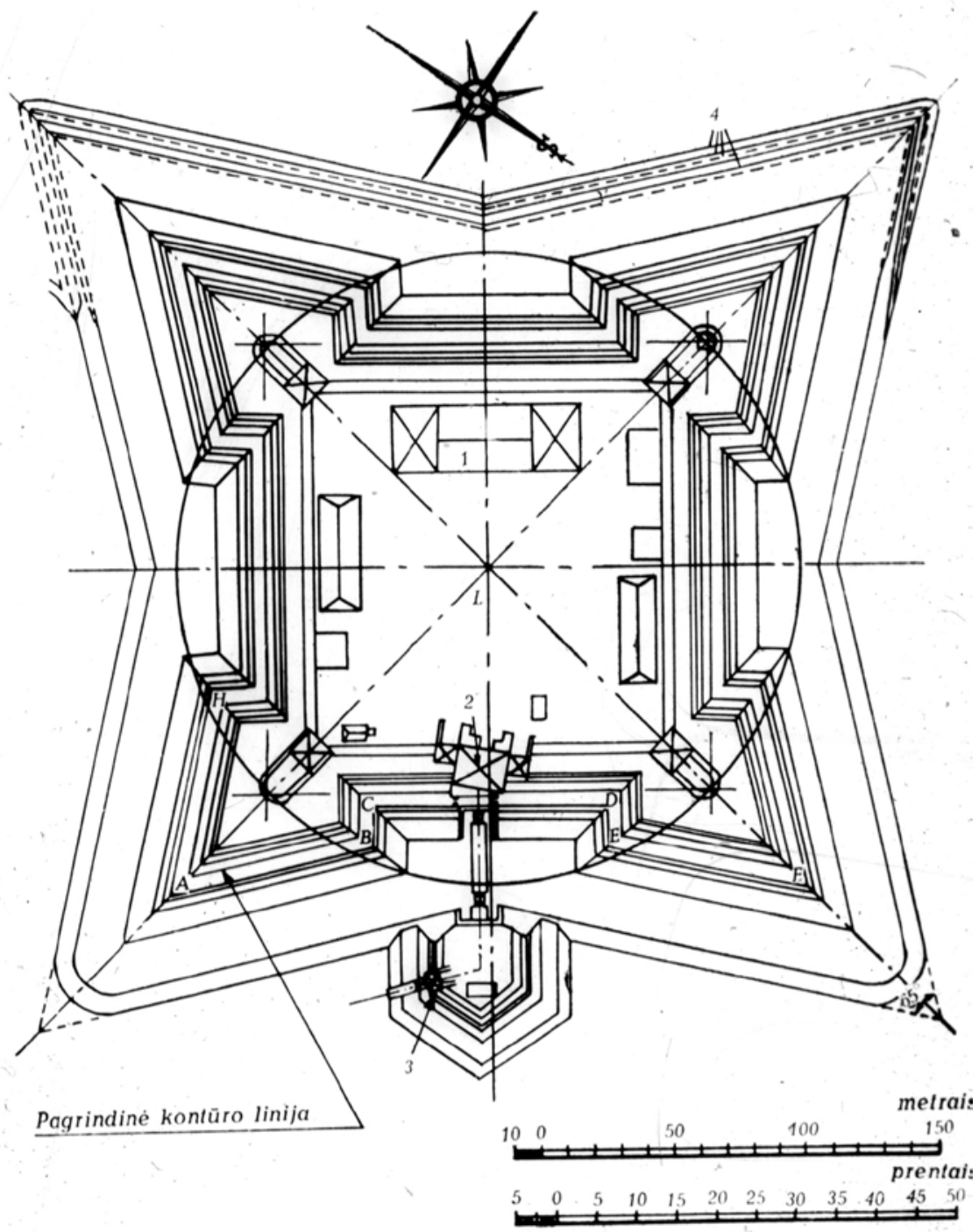

15

Biržų antrosios pilies gynybinių ịrenginių ir pastatų išdèstymo plano rekonstrukcija, in: Architektūros paminklai, t. 3, 1975, Vilnius: Mokslas, p. 141
Reconstruction of the layout plan of fortifications and buildings of the Biržai second castle 
centruose. Gana nežymūs nukrypimai nuo ašių atsirado išsaugojus vartų pastatą, o didžiausi - neplanuotai pastačius dvejas kareivines vakariniame bastione. Vartų pastatas lėmė nedidelius nukrypimus komponuojant arklides pilies kiemo šiaurès vakarų pusėje, sudarant kiemo kvadratą.

Iš daugelio išlikusių $\mathrm{B}$. Radvilos bei pilies statybų organizatoriụ laiškų galima suprasti, kokie svarbūs statybai buvo statinių projektai ir kiek daug jų buvo susikaupę. Deja, neišliko ar nerasta nė vieno iš korespondencijoje minimų projektų, negalime teksto iliustruoti autentiškais pilies statinių brèžiniais, negalime to ar kito pastato projekto palyginti su igyvendintu pastato variantu, juk nė vienas pastatas neišvengè pirminiuose projektuose numatyto architektūrinio vaizdo pakeitimų prieš pat jų statybą ar net jau ịsibėgèjus joms. Ypač kito rūmų ir arsenalo architektūra. Išliko keletas dokumentų, vaizdžiai iliustruojančių architekto ar paties B. Radvilos nurodymus, kaip ir kur statyti kai kuriuos statinius, keli pilies statytojų laiškai (neskaitant jų skundų dèl vienokių ar kitokių medžiagų trūkumo) iliustruoja statybų organizatorių ir iš Karaliaučiaus jų darbus sekančio, prižiūrinčio B. Radvilos bendradarbiavimo pobūdį. İdomu, kad Radvila ịsiklausydavo ị statybų organizatorių bei meistrų patarimus. Daugeliu atvejų šie patarimai ar pastabos turejjo įtakos statinių ar jų vidaus erdvių architektūrai. Spragos išlikusioje dokumentacijoje neleidžia atskleisti viso kūrybinio proceso ir ieškojimų vaizdo, tačiau jis akivaizdus net ir skaitant išlikusius dokumentus. Paskutini žodį, be abejo, tardavo B. Radvila. Žinios apie jo statytus pilies pastatus ir jų architektūrą bei konstrukcijas išdèstytos atsižvelgiant i ju statybos seką.

Kareivinès. Kareivinès (kordegardos) - penki vienaaukščiai keturšlaičiais stogais dengti nameliai, pastatyti pilies bastionų kakleliuose. Ketverios jų pavaizduotos 1704 m. plane [žr. 13, 15 il.]. Kareivinių vieta pilies kieme ir suplanavimas nustatyti daugelio archeologinių kasinėjimų metu ${ }^{49}$. Korespondencijos gausa padejjo gana aiškiai ịsivaizduoti jų statybų seką ir virsmą iš medinių ị mūrines, penktojo kareivinių pastato atsiradimo aplinkybes. Dèl vietos stokos negalime pailiustruoti visos turimuose istoriniuose dokumentuose matomos darbų sekos, apsiribojame šaltiniuose paminètomis architektūrą ir konstrukcijas nusakančiomis žiniomis. 
Architektas T. Spinovskis ir Kèdainių seniūnas L. Kochanskis patarè B. Radvilai kareivines statyti mūrines, nes tokiai šauniai tvirtovei bus gražiau ir saugiau nuo gaisro, iš mūro jos būsią greičiau pastatytos, nes miško medžiagos trūksta, jos sunku gauti ${ }^{50}$. Radvila nusprendè pilies atstatymą pradèti nuo kareivinių, o statytojams patarè jų pamatų giliai nedèti, nes sienos bus dviejų ar pustrečios plytos storio, be to - neaukštos ${ }^{51}$. Didikas manè, kad per vasarą bus galima išmūryti visas kareivines. Statybos vis dèlto užtruko, kartais jos likdavo be kvalifikuotos priežiūros. Žinutė iš pilies komendanto K. Karliko laiško paaiškina, kaip atsitiko, kad vietoj planuoto vieno pastato vakariniame kiemo kampe pastatyti du. Liepos 10 d. ì Biržus atvykęs S. Arciševskis rado pradètas mūryti kareivines nesilaikant T. Spinovskio projekto. Mat mūrininkas nutaręs, kad jos suprojektuotos per arti nuo rūmų (per 30 uolekčių), aiškinęs, kad kareivinès trukdytu kunigaikščiui, nes koks nors kareivis, kaip dažnai atsitinka, igèręs rikteltų ir kunigaikšti ne laiku prikeltų ${ }^{52}$.

Penktosios kareivinès pastatytos tame pat vakariniame bastione, kur jau buvo pastatytos pirmosios, tik jau kiek galima laikantis T. Spinovskio projekto. Ruošiant duobę penktųjų pamatams, teko ardyti kažkokio pirmosios pilies statinio mūrus. Kareivinès įkomponuotos didžiojo kiemo kampuose ant įejjimu i bastionus, vadinamuosiuose bastionų kakleliuose [žr. 13, 15 il.]. Kareivinių pastatai skyrè didịj pilies kiemą nuo kiemelių pilies bastionuose, kurių galuose po žemės pylimais buvo ịrengti parako rūsiai. Sprendžiant iš turimų duomenų, kareivinès vienodos, statytos pagal vieną projektą. Privažiavimui prie parakinių kareivinių pastatų viduryje buvo suformuoti 2,3-2,4 m pločio koridoriai-tarpuvartės. Trijų bastionų kareivinių pastatų simetrijos ašys įkomponuotos ant pilies įstrižinių ašių, o statant vakariniame bastione penktąsias teko šiek tiek nukrypti atsižvelgiant ị ne vietoje pastatytas pirmąsias kareivines. Atvykęs S. Arciševskis rado, matyt, jau gerokai pasistūmėjusią kareivinių vakariniame bastione statybą. Tikriausiai dèl to ne vietoje pradèto statyti kareivinių pastato negriauta.

Prie didžiojo pilies kiemo stovinčių penktujų kareivinių kontūras maždaug $17,5 \times 11 \mathrm{~m}$, sienos - 0,7 m storio. Vienoje patalpoje atidengtos neglazūruotų koklių krosnies liekanos. Grindys šioje patalpoje - plūkto molio. Manoma, kad prie bastiono gale buvusio parako rūsio privažiuodavo per

50 Stasys Pinkus, op. cit., 1971, p. 262. 


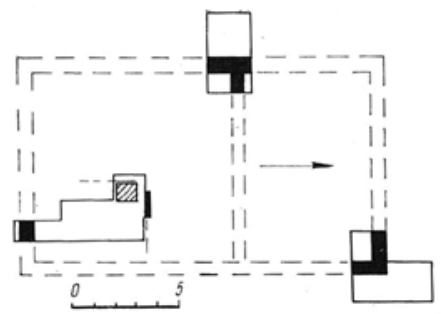

16.

Pastato, stovejusio vakarinio bastiono kiemelio gilumoje, plano rekonstrukcija. Pastato vidury, atrodo, buvo ir antra skersinè siena, in: Architektūros paminklai, t. 11, 1988, Vilnius: Mokslas, p. 50

Reconstruction of the plan of the building in the back of the courtyard of the western bastion

tarpą tarp dviejų bastione pastatytų kareivinių, tačiau žiūrint ị archeologo J. Genio pateiktą šio pastato sienų fragmentų planą, panašu, kad penktujuc kareivinių planas buvo kaip kituose bastionuose, su tarpuvarte [16 il.]. Šiaurinių kareivinių pastato išorinis kontūras - 14,5 × 11,5 m, pastato išorinès sienos - 0,64-0,8 m, vidinės, prie tarpuvartės, siekia 0,9 m. Kareivinių pietiniame bastione [17 il.] plano rekonstrukcija iliustruoja ir kareivinių visu bastionų kakleliuose suplanavimą. Sienų storis čia - 0,87 m.

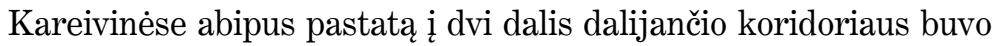
po dvi apie $25 \mathrm{~m}^{2}$ ploto patalpas, ị kurias buvo patenkama tik iš pastatą kertančio koridoriaus per 1,1-1,2 m pločio duris ${ }^{53}$. Langai galèjo būti tik sienose, atkreiptose i pilies didiji ir bastionų kiemelius, - po vieną kiekvienam kambariui. Remiantis archeologinių kasinėjimų medžiaga 1993 m. nubraižytas preliminarus kareivinių pastato ị didijj kiemą atkreipto fasado vaizdas $^{54}$ [18 il.]. Duomenų apie suplanavimą, durų angu pločius daugiausia gauta kasinejjant pietines kareivines, kampinių rustų dydžiai geriausiai atsiskleidè vakarinèse kareivinėse.

Langu dydis $1993 \mathrm{~m}$. pavaizduotas neturint T. Spinovskio $1664 \mathrm{~m}$. sausio 20 d. laiško teksto su čia nurodytais arsenalo ir arklidžių langų, durų, vartų angų, aukštų aukščių ir kitų architektūrinių elementų matmenimis [žr. skirsnị apie arsenalą]. Šiandien 1993 m. brèžiniuose pavaizduotų kareivinių langų matmenis jau galima patikslinti - kareivinès priklauso mažesniujju pilies statinių grupei, jų architektūrinè išraiška, architektūrinių elementų dydžiai ir formos turèjo būti kaip atitinkamų arsenalo architektūrinių elementų dydžiai: kambarių aukštis - 3,63-3,9 m, langai - 1,66-1,78 m aukščio, $1,06-1,13$ m pločio.

53 Jonas Genys, Arūnas Baublys, op. cit., p. 214.

54 Evaldas Purlys, Biržų pilis: pilies pastatai kieme archeologinių tyrimų duomenimis, 1993, in: VRVA, f. 5-5635. 


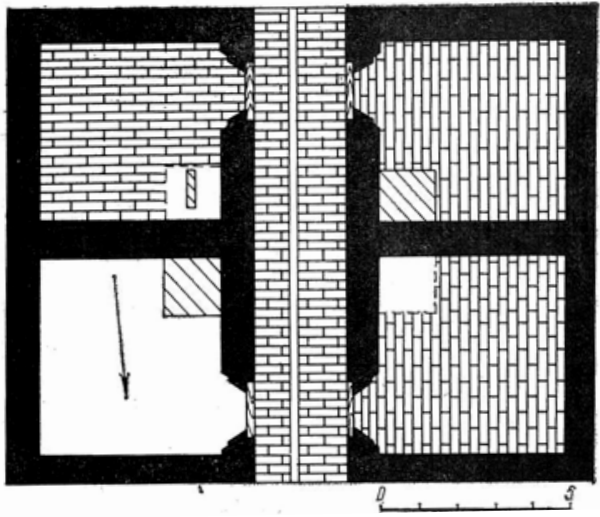

17.

Pastato, stovejusio pietiniame bastione, plano rekonstrukcija, aut. Jonas Genys, in: Architektūros paminklai, t. 11, 1988, Vilnius: Mokslas, p. 48

Reconstruction of the plan of the building that stood in the southern bastion

Kareiviniu kambariai ir koridorius-tarpuvartė buvo perdengti medinėmis atviro medžio sijų ir lentų perdangomis. Grindys pietinėse kareivinėse grịstos plytomis, klotomis plokščiaja puse eilėmis. Pasitaiko asla ar lentų grindys. Koridoriuose-tuneliuose - plytos. Sienos visose patalpose tinkuotos, kambarius šildè koklinès krosnys. Aptikti 1,5 × 1,5 - 1,6 × 1,6 m krosnių padai, daug neglazūruotų ir žaliai glazūruotų koklių fragmentų. Virš perdangų buvo smèlio sluoksnis, skirtas šiluminei izoliacijai ar, greičiau, priešgaisrinei apsaugai. Kareivinių, kaip ir kitų statinių, stogai buvo dengti „olandiškomis“ čerpèmis ${ }^{55}$.

Parakines. Istorikų darbuose ir dokumentuose apie parakines kalbama labai nedaug - tik 1668 m. liepos 24 d. laiške nurodoma „tinkuoti rūmų rūsius ir statyti parakui laikyti sandèlius" ${ }^{\text {"56 }}$.

Parakinių erdvė buvo dviejų patalpų. Priekyje buvo pusiau požeminè $3,82 \times 1,55 \mathrm{~m}$ ploto priemenè su durimis sienoje, atkreiptoje ì kiemeli, gilumoje - požeminè cilindriniu skliautu perdengta $6,65 \times 3,84 \mathrm{~m}$ ploto patalpa.

XX a. 6 deš. šiauriniame bastione buvo surastas pirmas pilies parako rūsys. Išliko pagrindinès patalpos skliautas. Bene mažiausias parako rūsio fragmentas buvo likęs vakariniame bastione. Čia tebuvo galinè siena ir apie 2 m pagrindinès patalpos skliauto. Apie $1983 \mathrm{~m}$. tiesiant inžinerines komunikacijas atsidengè parakinès pietiniame bastione liekanos - rasta didelè dalis pagrindinės patalpos skliauto ir visų parakinės sienų apačia [19 il.]. 


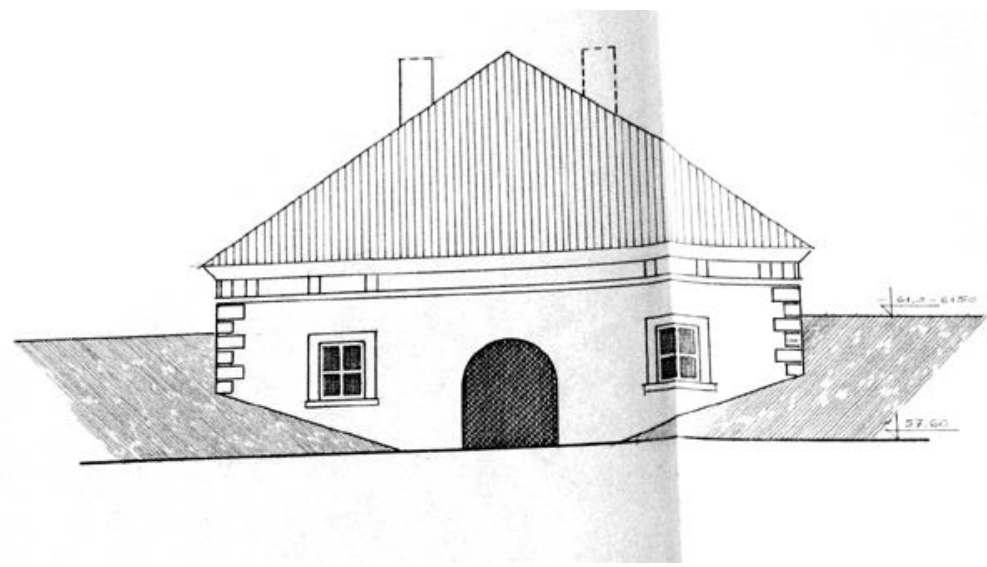

18.

Pastato, stovejusio pietiniame bastione, fasado rekonstrukcija, 1993

Reconstruction of the façade of the building that stood in the southern bastion

Autentiškos plytų grindys, ant kurių rastas nuvirtęs priekinės parakinès patalpèlès skliautuko fragmentas, padèjo išsiaiškinti, kokiu skliautu buvo perdengta priekinė parakinės patalpèlè. Priekinės patalpėlès sienos išsaugojo ir dar vieną kitur neišlikusią žinią - durų angokraščius su medinių staktų atspaudais bei šių elementų matmenimis, skerspjūviais ir pan. Palyginus trijų aprašytų parakinių matmenis, pasimatè, kad pietinės ir vakarinès parakinės buvo vienodo pločio ir ilgio, vienodas buvo pagrindinių rūsio patalpu bei jų skliautų lanko aukštis.

Arsenalas [20 il.]. B. Radvilai apie 1660 m. perèmus pilies statybas, arsenalas buvo vienas iš išlikusių, greičiausiai prieš karą, tarp 16371655 m., statytų pastatų. Šio pastato pamatų fragmentai, rasti 2008 m. ir $2010 \mathrm{~m}$. kasinèjant arsenalo plotą, eksponuojami arsenalo ekspozicijų salèje. Jo būta apie $73 \mathrm{~m}$ ilgio, apie 7,5 m pločio su mediniu karkasu sienose pastato.

$1659 \mathrm{~m}$. atgavus pili arsenalas buvo tik pusiau dengtas čerpèmis, paramstytas, kad nesugriūtų ${ }^{57}$. Kitų metų vasarą imtasi ji gelbèti. Arsenalas būtų nuvirtęs, nes tarp mūrų stulpai buvo supuvę ${ }^{58}$. Stulpai (fachverko konstrukcija (?)) pakeisti naujais, pastatas uždengtas nuo seno namo nuimtomis čerpèmis. Tai buvo ištịsęs, siauras (120 uolekčių ilgio, 12 uolekčių 


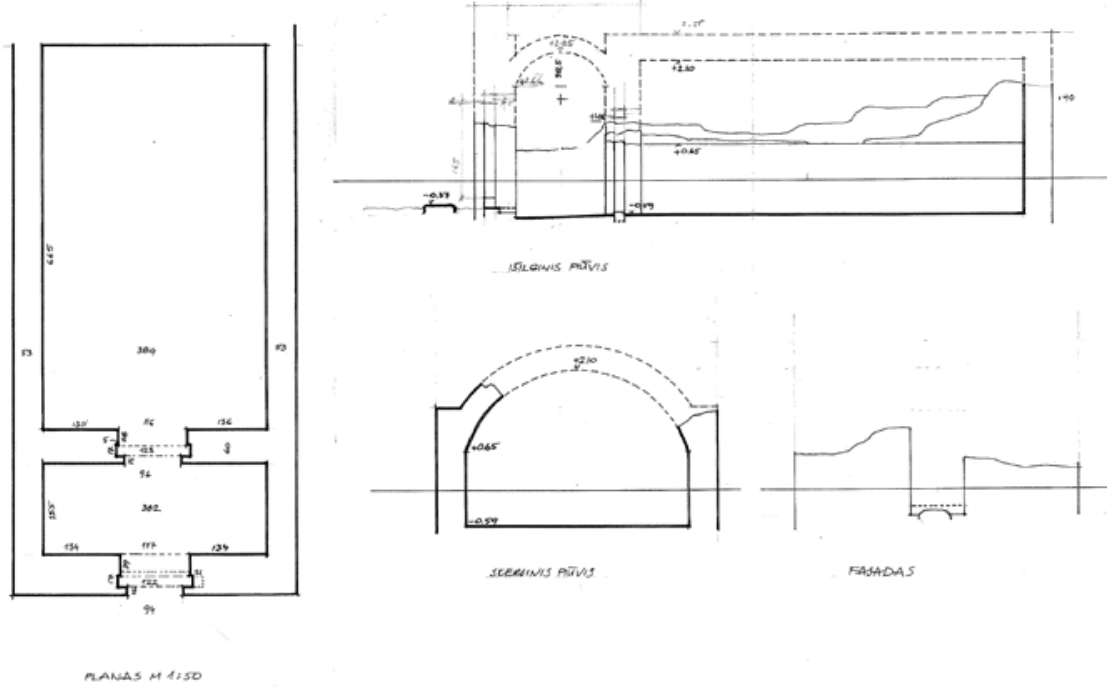

19.

Parakinès pietiniame bastione liekanu apmatavimai, Measurements of the remains of the powder house in braižè Evaldas Purlys, apie 1983 the southern bastion

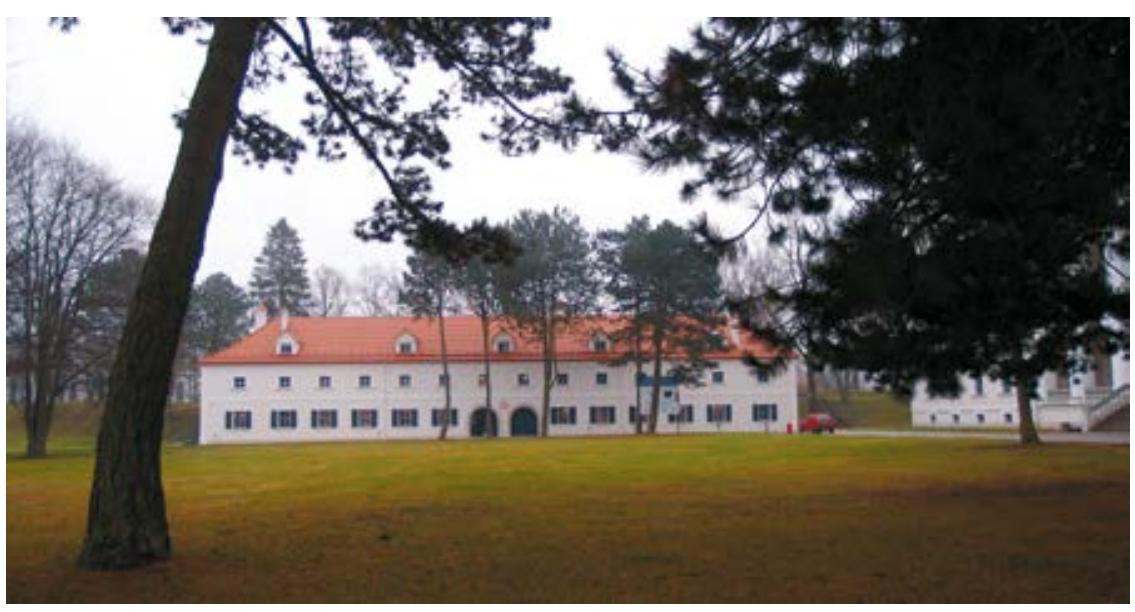

20.

Biržų pilies arsenalas, Evaldo Purlio nuotrauka, 2013 Arsenal of the Biržai castle

Evaldas Purlys

Biržu pilies statinių architektūra ir jos raida 
pločio) pastatas ${ }^{59}$. Išlikusiuose pamatų mūruose medinių konstrukcijų žymių nerasta.

Naujojo arsenalo projektai. Projektuoti naują arsenalą imtasi tik 1663 metais. L. Kochanskis pasiūlè ji sutrumpinti iki 90 uolekčių ir, pristačius antrą aukštą, paversti tą aukštą maisto sandèliu ${ }^{60} .1663 \mathrm{~m}$. vasarą nugriauta dalis [senojo, $-E$. P.] arsenalo ${ }^{61}$. Iš arsenalo statybų laikotarpio laiškų galima suprasti, kad pirmini jo eskizą parengè pats B. Radvila. T. Spinovskis šiek tiek jị pakoregavęs nubraižè fasadą, o kiek vẻliau paprašytas laiške nurodè ir visus pagrindinius matmenis. Radvilos prašymas atsiųsti matmenis reiškè, kad jis atsiųstam projektui pritarè, o epizodas su atskirai nuo brèžinio laiške nurodytais matmenimis iliustruoja neịprastą mums ir nežinia kiek paplitusi projektų rengimo ir informacijos brèžiniuose pateikimo variantą. Nubraižytas buvo tik vienas [pagrindinis, $-E$. $P$.] fasadas, o pateikiant duomenis apie planą apsiribota patalpų vidaus matmenų ir sienų storių nurodymu minètame laiške. Pagrindinis dėmesys skirtas fasado architektūrinių elementų matmenims. Laiške nurodyta ir durų vieta bei jų matmenys.

Deja, matmenimis laiške užbaigtas projektas neilgai tegaliojo B. Radvila nežinia kieno patartas ar geriau apsižiūrèjęs nurodè T. Spinovskiui pakoreguoti savo paties pasiūlytą, architekto užbaigtą projekto variantą. Duomenų apie pakoreguoto arsenalo vaizdą, išskyrus archeologinius ir kelias svarbias detales statybos meto laiškuose, nèra. Atskiri brèžiniai vèliau ruošti stogo konstrukcijai ir laiptams, tačiau stogas kažkodèl buvo suremtas gerokai nukrypstant nuo projekto. Nežinia, ar B. Radvila bus nurodęs permontuoti jau gerokai pasistūmėjusią stogo konstrukciją. Būta ir daugiau projektų, skirtų arsenalui, laiškų su tos ar kitos konstrukcijos aptarimais.

Iš nemažo arsenalo dokumentacijos pluošto liko T. Spinovskio laiškas su arsenalo ir jo architektūrinių elementų matmenimis bei keli Radvilos laiškai su nurodymais, kaip daryti tą ar kitą pastato elementą. Minètus arsenalo architektūrinio sprendimo ieškojimus vaizdžiai iliustruoja T. Spinovskio $1664 \mathrm{~m}$. sausio 20 d. laiško pradžia. Pastatų įkomponavimas kieme buvo aptartas prieš pradedant statybas, todèl šiame laiške apie arsenalo ir arklidžių komponavimą kieme nekalbama: 
siunčiu $<\ldots>$ kunigaikščiui $<\ldots>$ arklidžių ir būsimo Biržų arsenalo brèžinị [paryškinta, - E. P.], t. y. arklidžių planą (gruntris) ir abiejų minètų pastatų fasadą [paryškinta, - E. P.], nubraižytą pagal kunigaikščio planą ir sumanymą, su visomis jam pastatyti reikalingomis aplinkybėmis. Ir nors kunigaikštis norejjo, kad aš ant kunigaikščio projekto (abrysie) tiktai nurodyčiau atstumus tarp langų ir kitas detales aprašyčiau tik žodžiais, tačiau, kadangi storis vidinių $<\ldots>$ durų ir langų paprastai labai varijuoja, taip pat ir $<\ldots>$ laiptų, todèl nusprendžiau nubraižyti visai naują brèžinị [...].

Dabartiniame savo projekte kunigaikščio nurodytus išmatavimus pakeičiau nedaug, tik viduje kambarius reikėjo šiek tiek sumažinti. ${ }^{62}$

Iš dar vienos laiško atkarpos, kurioje nuorodomi vartų i arsenalo priemenę matmenys, galima suprasti, kad ir pačią idèją - pagrindinị ieejjimą akcentuoti dvigubais vartais - galèjo pasiūlyti Radvila:

Vidurinius vartus arba portalą savo brèžinyje daviau 9 pėdų ${ }^{63}$, arba 4,5 uolekčio, pločio; <...> o stulpas arba piliastras vidurinis, kuris tuos dvejus vartus skiria, sudaro 4 pėdas arba 2 uolekčius pločio; taip pat, nuo vienos šoninės pertvaros iki kitos yra 24 pėdos, arba 12 uolekčių, kaip ir kunigaikščio projekte [paryškinta, $-E$. P.].

Tiek dėmesio laiško atkarpai su vartų matmenų aprašymu skiriame dar ir dèl to, kad turime galimybę palyginti natūroje išlikusių detalių matmenis su nurodytais laiške. Laiške aprašyti vartai ir priemenė kasinėjimų metu rasti natūroje - arsenalo pastato centrinejje dalyje. Labai artimi aprašytų laiške ir natūroje išlikusių elementų matmenys - pagrindinis, raiškiausias T. Spinovskio $1664 \mathrm{~m}$. sausio $20 \mathrm{~d}$. laiške paminètame projekte sumanytas abiejų namų kompozicinis akcentas - sudvejinti vartai arsenale buvo igyvendintas tiksliai pagal laiške nurodytus matmenis. İdedame kelias ištraukas su itin svarbiais, lèmusiais arsenalo atkūrimo projektą matmenimis:

62 T. Spinovskio 16640120 laiškas, in: Lietuvos mokslų akademijos Vrublevskių bibliotekos Rankraščių skyrius (toliau - LMAVB RS), f. TF-3, 1, 52, 53.

63 LDK pèda - 0,325 m; 1704 m. švedų pèda - 29,69 cm; Reino pėda lygi 31,385 cm. 
Pirmo ir viršutinio aukšto aukščiai yra tokie pat kaip kunigaikščio projekte, tai yra apatinio, aukštesniojo, aukštis 6 uolekčiai, arba 12 pėdų [apie 3,63-3,9 m]. $O$ viršutinio 5 uolekčiai, arba 10 pèdų [apie 3,02-3,25 m]

Vartų arba portalų aukštis nuo žemės iki arkų viršaus turi sutapti su žemutinių langų viršumi, tai yra čia turi būti 9,5 pėdos, arba penki uolekčiai be ketvirčio [apie 2,85 m]; Piliastro arba vidurinio tarp vartų esančio mūro aukštis nuo žemės iki imposto viršaus, kur arkada prasideda, yra 5 pėdos, arba pustrečio uolekčio [apie 1,5 m].

Viso pastato visų langų, taip pat užpakalinių išorinių durų plotis 3,5 pėdos, arba du uolekčiai be ketvirčio. Aukštis [langu]] pirmame aukšte 5,5 pėdos, arba trys uolektys be ketvirčio; antrame aukšte toks pat kaip plotis, tai yra 3,5 pėdos. O pastogès languose aukštis pusę pėdos mažesnis nei plotis, tai yra 3 pėdos, arba 1,5 uolekčio. Apatinių langų atstumas nuo žemės 4 pėdos arba 2 uolekčiai. O vidurinių nuo juostos (kuri žemutinį aukštą nuo viršutinio atskiria ir lygiai su viršutinio aukšto grindimis turi apibėgti visą pastatą) atstumas 3,5 pėdos; ir toks pat turi būti atstumas tú langų, kurie pastogejje, nuo vainikuojančio karnizo, kuris stogą atskiria.

Abiejų aukštų pirmujjų kraštinių langų atstumas nuo kampinių rustų (cantonatow) arba piliastrų ị vidų tiek išilgai tiek skersai pastato yra 6 pėdos, arba 3 uolekčiai; o visų kitų langų (išskyrus vidurinius, kurie yra virš vartų (nes šie prie vidurinių vartų turi derèti) atstumas nuo vieno lango vidurio iki kito lango vidurio yra 12 pèdų, arba 6 uolekčiai.

\section{Žinios iš arsenalo statybụ. Dar karta apie projekto papildymus}

ir korektūras. Po ilgai trukusių atidèliojimų ir pasiruošimų arsenalas kilo labai sparčiai. 1664 m. gegužès pradžioje imta ruošti vietą arsenalo pamatams $^{64}$, birželio mėnesi pamatai jau padèti, o liepos viduryje jo sienos jau buvo išmūrytos ${ }^{65} .1664 \mathrm{~m}$. liepos $18 \mathrm{~d}$. L. Kochanskis jau prašè atsiųsti arsenalo langų projektus ${ }^{66}$ (matyt, arch. T. Spinovskis taip pat buvo Karaliaučiuje). Iš Karaliaučiaus arsenalo statybą stebintis B. Radvila, igavęs patirties po mūrininko improvizacijų statant pirmąsias kareivines, laiške, rašytame $1664 \mathrm{~m}$. liepos $23 \mathrm{~d}$., perspejja statybu vadovus:

Rašo man [B. Radvilai], kad arsenalo sienos išmūrytos; nenorěčiau, jei ceikhauzo matmenyse ir konstrukcijose būtų suklysta; šito niekad neatleisčiau: visame kame 


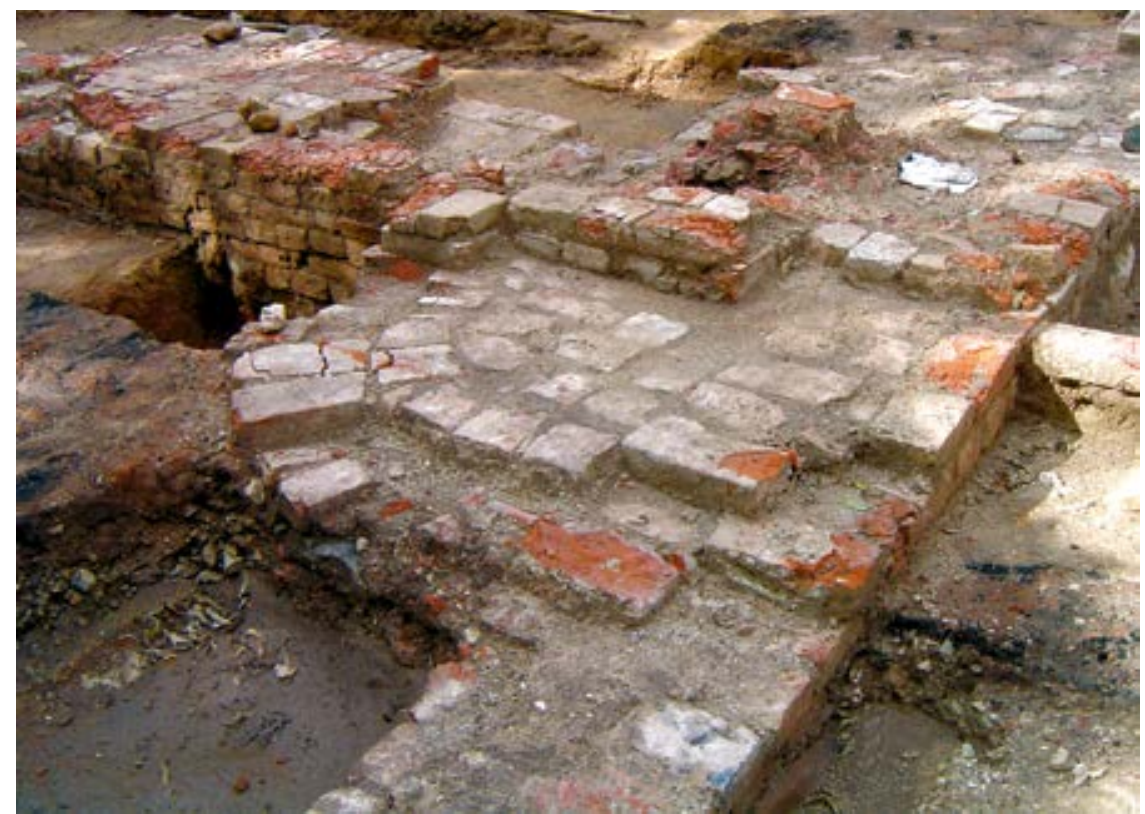

21

$1664 \mathrm{~m}$. statyto arsenalo mūrų liekanos. Kampinio

Remains of the walls of the arsenal built in 1664 židinio padas ir gaubto atramos fragmentas, Evaldo

Purlio nuotrauka, 2008

laikykis paskutinių matmenų, kuriuos atsiunčiau pono Spinovskio laiške, kur viskas išraiškingai aprašyta, kaip ką turi statyti < ...> Jeigu išvažiuosi, visus projektus, matmenis ir pono Spinovskio laiškus palik ponui Karlikui ar ponui Kochanskiui. Sudaryk visko, ką atiduosi, sąrašus [paryškinta, $-E$. P.]. <...> Laiptai i viršų, kur dveji vartai bus, turi būti prie sienos, ne siauri ir ne per platūs. Langai stoge tegu būna kaip pono Spinovskio projekte [...]. ${ }^{67}$

Šis B. Radvilos laiškas S. Arciševskiui yra kol kas vienintelis žinomas dokumentas, iš kurio sužinota laiptų i viršų vieta. Laiptai buvo priemenėje, mediniai. Priemenès grindys iš lauko akmenų, patalpos centre liko pamatas stulpui, laikiusiam perdangos konstrukciją. Apie priemenės šoninėse sienose buvusius vartus sužinome iš $1674 \mathrm{~m}$. inventoriaus, kuriame aprašius įèjimo vartus tęsiama: „I patị Ceikhauzą dveji, vieni prieš kitus vartai.

67 B. Radvilos 16640723 laiškas Arciševskiui, in: AGAD, sygn. 772, p. 5; elektroninė dokumento kopija Biržų krašto muziejuje „Sèla“. 
Natūroje šiose vietose nerasta pamatų. Vartų angos šoninėse priemenès sienose ar viena iš jų buvo maždaug tokio pat pločio kaip išorinėje sienoje“.

Žinia apie vieną iš projekto pakeitimų atėjo liepos mėnesį. Arsenalą statant naudotasi tiek senu, tiek nauju T. Spinovskio projektu. Todèl netiko Spinovskio stogas ${ }^{68}$. Pilies komendantui Karlikui teko išdėstyti prieštaringumus projektuose, eilinį kartą atsiklausti B. Radvilos. Kartu komendanto laiške yra išdèstyta ir labai svarbi žinia apie stogo konstrukciją. Laiku apie ją sužinojus turbūt galėjo kiek kitaip pakrypti atkuriamo arsenalo projektavimas:

liepos 19 d. atėjo laiškas, o prie jo brèžinys, pagal kurị turèjo būti statomas stogas virš Ceikhauzo. Atsiųstas brèžinys nesutampa su pono Spinovskio brēžiniu, nes ir karnizas kitoks, ir gegnès keliais uolekčiais [paryškinta, $-E$. P.] aukštesnès nei pono Spinovskio nurodytuose matmenyse. <...> dalis gegnių ir karnizo pastatyta dar prie pono Arciševskio, pagal seną projektą <...> Po tuo stogu yra du grendymai - vienas, apatinis, pusketvirto uolekčio aukščio, čia galima vaikščioti nesusilenkiant; antras, viršutinis dviejų uolekčių aukščio (latow) ir kitų smulkmenų saugojimui, čia jau susilenkus reikia vaikščioti. Iš viso nuo perdangos iki pačio stogo viršaus septynios uolektys. Dèl ko jis gerai matomas iš už pylimo [paryškinta, E. P. $][. . .]^{69}$

Antrasis grindų lygis turèjo būti ịrengtas virš stogų konstrukcijose naudojamo horizontalaus skersinio. Šiuo atveju racionaliausiai pastogès erdvè būtų išnaudojama ịrengiant vadinamajị barokinị, mansardinị stogą. Siekiant iki galo išsiaiškinti 1664-1665 m. pastatyto arsenalo architektūros elementų formas ir dydžius, reikia papildomų istorinių dokumentų studijų ir paieškų. Be to, nežinia, ar stogas su net keliais uolekčiais per aukštomis gegnèmis buvo žeminamas, nes rugpjūčio pabaigoje jau buvo dengiamas arsenalo stogas, tinkuojamos sienos ${ }^{70}$. Keturi mūrininkai pastatą tinkavo iki 1665 m. gegužès pabaigos ${ }^{71}$.

Biržų muziejuje saugomi keli kasinejjimų metu surasti vainikuojančio karnizo profilių fragmentai. Arsenalo langų išsidèstymą rodo kasinẻjimų metu prie išorinių sienų surastos stiklo duženų sankaupos. Surasta

68 Stasys Pinkus, op. cit., 1971, p. 268.

69 K. Karliko 16640731 laiškas B. Radvilai, in: LMAVB RS, f. 31-948.

70 Stasys Pinkus, op. cit., 1971, p. 268.

71 Ibid. 


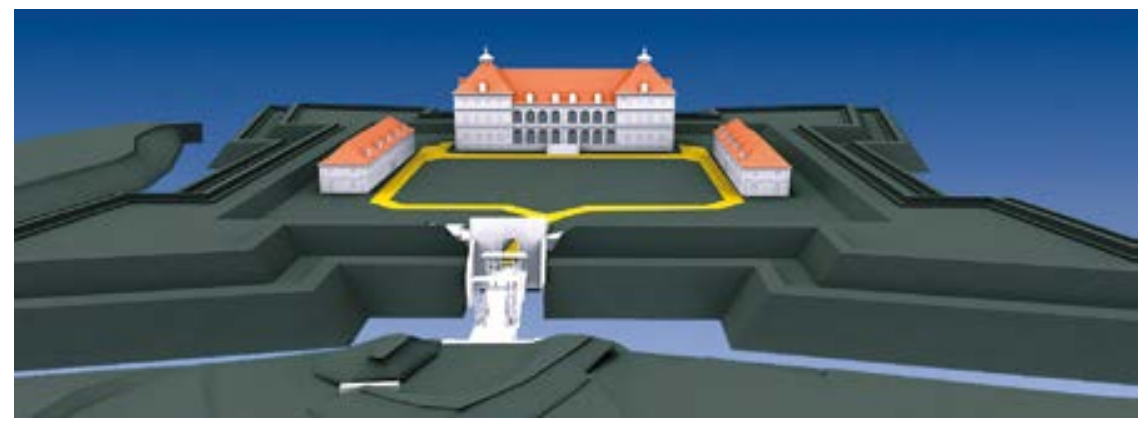

22.

Arsenalo ir arklidžių komponavimas pilies kieme pagal Teofilio Spinovskio projektą, braižè Robertas Bardauskas, 2009
Composition of the arsenal and the stables in the castle's courtyard according to T. Spinowski's project

keliolika langų vidinių angokraščių ǰžambumo kampą iliustruojančių plytų, taip pat apie dešimt plytų su išima metalinėms išorinėms langinėms.

Apie arsenalo patalpų paskirtis ir jų interjerus. Provianthauzas būdavo neatskiriama viršutinè ceikhauzo pastato dalis. Viršutinis aukštas buvo ir naujajame B. Radvilos ir T. Spinovskio arsenale. Labai vaizdžiai arsenalo vidų iliustruoja $1665 \mathrm{~m}$. vasario $14 \mathrm{~d}$. B. Radvilos rašytos instrukcijos S. Arciševskiui 13 punktas:

Taip pat reikia pažiūrèti, kaip užbaigtas arsenalas: ar langai pagal mano matmenis ịrengti, ar pats ceikhauzas visas geromis storlentėmis išgrịstas, ne akmenimis, ar viršutinis užpylimas tiek izoliuotas, kad dulkès ant patrankų ir šautuvų nekristų, ir ar ant grindų grendimas iš molio kuo geresniam grūdų laikymui gerai padarytas. Tame pat ceikhauze tegu prie sienų, kaip ir kituose ceikhauzuose, bus laikomi šautuvai, ietys, šarvai [...]. ${ }^{72}$

Norėdamas sulaikyti pilyje dirbusị ir panorėjusị i Vilnių išvažiuoti tapytoją, drožèją ir skulptorių Joną Bohdaševskį73, Karlikas pasiūlè Radvilai leisti jam išpuošti arsenalo lubas, kaip buvo ir senajame arsenale ${ }^{74}$. Radvilos nurodymu visas arsenalas buvo nudažytas baltai, išskyrus vidinius

72 B. Radvilos 16650214 instrukcija Arciševskiui, in: AGAD, Sygn. 774, p. 8, 9; elektroninė dokumento kopija Biržų krašto muziejuje „Sèla“.

73 Plačiau apie Joną Bohdaševskị žr:: Lietuvos dailininku žodynas, t. I: XVI-XVIII a., sud. Aistė Paliušytė, Vilnius: Kultūros, filosofijos ir meno institutas, 2005, p. 75-76.

74 Stasys Pinkus, op. cit., 1971, p. 269. 


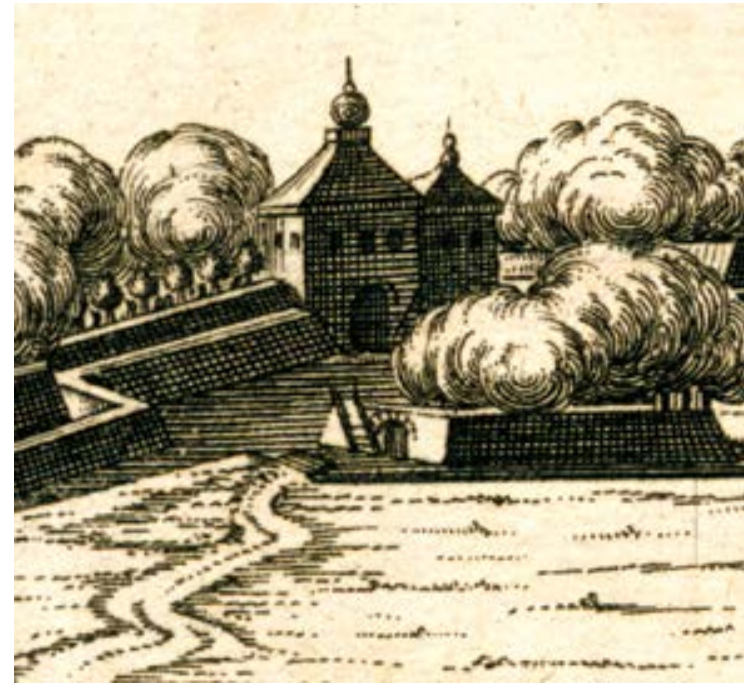

23.

Redutas prieš tiltą per fosą ir vartų bokštai. Nedidelè fosa ir tiltas per ją buvo ir prieš redutą. $1704 \mathrm{~m}$. graviūros fragmente matome pakeliamaja tilto dalimi pradedamą dengti reduto vartų pastato angą. Pastatas buvo mūrinis, tiltas medinis, ant medinių stulpų, apie $15 \mathrm{~m}$ ilgio. Apie $1963-1965$ m. reduto tilto ir vartų plote kasinėjo Karolis Mekas

Redoubt in front of the bridge over the moat and the gate towers

skliautus, kurie buvo juodi. Ant vienų arsenalo durų buvo nutapytas patrankininkas, uždegantis patrankos dagtị, ant kitų - patrankininkas, šaunantis iš mortyros $^{75}$. Medinès arsenalo grindys, kaip reikalavo B. Radvila, buvo padarytos. Kasinėjimų metu atidengti atkurtame pastate eksponuojami per 1704 m. gaisrą sudegusių medinių grindų ir gulekšnių likučiai ar pėdsakai, viename kambaryje rastos turimuose šaltiniuose nepaminèto židinio liekanos [21 il.].

Arklidès. Jų vietą pilies kieme ir architektūrą ịtaigiausia nusakyti B. Radvilos ir T. Spinovskio žodžiais: „Priešais ceikhauzą turi būti tokio pat ilgio kaip ceikhauzas arklidès“76 [22 il.], ,,arklidžių vieta numatyta projekte ${ }^{77}$ [paryškinta, $-E$. P.], kadangi vartai nèra kurtynos centre, iš miesto ateinant jie yra šiek tiek dešinėje. Arklides reikia statyti šiek tiek arčiau pylimo nei ceikhauzas. Jei to negalima, reikia stebèti, kad nebūtų deformuotas kiemo kvadratas"778. Radvila galvojo toje vietoje, kur stovėjo virtuvė, pastatyti arklides (tokias kaip ceikhauzas), o virtuvę pastatyti senųjų arklidžių vietoje ${ }^{79}$. Žemiau įdedama skirtumus tarp arsenalo ir arklidžių architektūros nusakanti ištrauka iš ne kartą minèto T. Spinovskio laiško:

75 Deimantas Karvelis, Biržų pilies komplekso istoriniai tyrimai, p. 94.

7616640723 B. Radvilos laiškas Arciševskiui, in: AGAD, Sign. 772, p. 5, 9. Deimanto

Karvelio atvežtoje elektroninejje dokumento kopijoje Biržų krašto muziejuje „Sėla“.

77 Greičiausia turimas galvoje T. Spinovskio parengtas pilies naujos struktūros planas.

7816650214 B. Radvilos instrukcija Arciševskiui, in: AGAD, Sign. 774, p. 8, 9. Deimanto Karvelio atvežtoje elektroninėje dokumento kopijoje Biržų krašto muziejuje „Sèla“.

79 Stasys Pinkus, op. cit., 1971, p. 270. 
arklidžių langai tiek priekyje, nuo kiemo, tiek ir galiniai, nuo pylimo, virš èdžių turi būti užmūryti nuo apačios ị viršų per 5 pėdas, taip, kad tik ịilinimu (išoriniu aprèminimu) derètų su kitais langais, o [neužmūrytas] likutis, t. y. pusantros pèdos angos turi būti paliktos dèl apšvietimo virš èdžių, taip, kaip parodyta fasado brèžinyje. To nereikia [daryti] arsenale, nes ten visi langai reikalingi apšvietimui $<\ldots>$. Arklidžių kambariuose ir priemenėse vidinių durų [plotis] turi būti pilnos 3 pėdos, tai yra pusantro uolekčio; o aukštis - 6 pėdos, arba 3 uolekčiai, tai yra dvigubai daugiau nei plotis. $\mathrm{O}$ užpakalinės išorinès durys, kuriomis ị pastatą įeinama, aukštis turi būti 7 pėdos, arba pusketvirto uolekčio; ir virš jų langelis ${ }^{80}$.

Vartų pastatas. Graviūroje, vaizduojančioje Biržu pilies puolimą 1704 m. rugpjūčio 16 d., pilies rytiniame šone prieš redutą pavaizduotas pastatas su dviem bokštais [23 il.]. Didesniojo (pietinio) bokšto rytinèje sienoje tilto gale pavaizduota vartų anga, viršuje, antrame aukšte - trys langai ar šaudymo angos. Bokštų stogai keturšlaičiai su kupoliukais. Pagrindinis vartų tūris buvo suformuotas dar Kristupo I, pertvarkytas Kristupo II Radvilos, remontuotas Jonušo Radvilos. 1662 m. parengtas Boguslavo Radvilos pilies vartų rekonstrukcijos projektas ${ }^{81}$. Sumanyta praplèsti senaji vartų pastatą, kad jame būtų galima gyventi, kol bus užbaigti rūmai ${ }^{82}$. Darbai užtruko net iki 1663 m. galo. Prireikè nukasti pylimą būsimų paviljonų plotuose, išvežti nemažai smėlio, teko laužti po pylimu buvusius rūsius ${ }^{83}$.

Pagrindinị vartų tūrị sudaro 19,6 × 16 keturkampis, kurio vidury 1,7 ir 1,3 $\mathrm{m}$ storio sienomis buvo atitverta tarpuvartè. Tarpuvartès ilgis $16 \mathrm{~m}$, plotis - apie 4,5 metro. Abipus jos esančios patalpos $1,8 \mathrm{~m}$ storio siena padalytos į dvi dalis. Vienų patalpų plotas $4,0 \times 7,5 \mathrm{~m}$, kitų - 4,0 × 3,0 metrų. Didžioji patalpas skaidančios sienos dalis yra senujų Kristupo I Radvilos vartų vakarinè siena. Pastačius priestatus centrinis tūris pasipildè šoniniais dviejų aukštų, $8,0 \times 8,0 \mathrm{~m}$ paviljonais. Kiemo pusėje įrengti prašmatnūs atviri ar pusiau atviri laiptai ị antrą aukštą. Pirmame vartų aukšte buvo šešios patalpos, antrajame - dešimt. Dalis patalpų (greičiausia pirmame aukšte) priestatuose buvo skliautuotos, o sienų mūrai sutvirtinti metalu ${ }^{84}$. 
Priestatų karnizai formuoti iš profiliuotų plytų $\iota^{85}$. Po priestatais įrengti tinkuoti rūsiai ${ }^{86}$. Jie neatkasti, kažkur turètų būti ièjimai ị juos ${ }^{87}$.

Natūroje tyrinèti mūrai sudaro kontūrus, kurių struktūra [žr. 11 il.] daugmaž sutampa su $1704 \mathrm{~m}$. plane pavaizduotais vartų kontūrais. Šiame plane pavaizduotos pastatų stogų schemos ir graviūra rodo ant pagrindinio vartų tūrio ir paviljonų buvusius keturšlaičius, panašius kaip virš rūmų rizalitų, stogus. Panašūs, matyt, buvo ir kupoliukai ant stogų viršūnių.

Apie vartų patalpų dekora. Iš S. Arciševskio, kuris tuo metu dirbo pilyje, laiškų matyti, kad rengiant priestatus (paviljonus) buvo derintasi prie anksčiau ịrengtų interjerų ir jų dekoro. Pavyzdžiui, $1662 \mathrm{~m}$. liepos $21 \mathrm{~d}$. Arciševskis prašè nurodyti, kokias priestatuose daryti lubas - paprastos būtų nepanašios i kitų senų kambarių lubas, todèl jas reikètų pavesti išpuošti skulptoriui arba pakabinti paveikslus, kaip kituose kambariuose $e^{88}$, 1662 m. rugpjūčio 21 d. S. Arciševskis rašė B. Radvilai, kad langus priestatams skulptorius darąs tokius, kaip senieji, staktas gi, kurios senuose kambariuose yra akmeninès, teksią daryti ị jas panašias ąžuolines ${ }^{89}$. Iš kai kuriu dokumentų galima suprasti, kad langai buvo įmūrijami statant paviljonų sienas, o ne ịstatomi i angas pastačius sienas ${ }^{90}$. Skulptorius J. Bohdaševskis $1662 \mathrm{~m}$. išpjaustė (?) vartų priestatų langụ rėmus, $1663 \mathrm{~m}$. dekoravo tụ vartų fasadą dažytais ir skulptūriniais ornamentais bei Radvilų herbais, o 1664 m. išraižè įrašus marmuro lentoje po pilies ịkūrejjo Kristupo I Radvilos Perkūno biustu, pastatytu virš vartų [angos, $-E . P.]^{91}$. Vartų pastatas buvo vienas labiausiai užbaigtų, puošniausiai įrengtų Biržų pilies pastatų. $1674 \mathrm{~m}$. inventoriuje aprašomas stambus mūrinis dviejų aukštų pastatas su rūsiais. Langų, durų rẻmai buvo iš medžio, dailiai išpjaustyti, apkalai dažyti, pastatas buvęs turtingai ịrengtas, ị antrą aukštą vedę laiptai buvę akmeniniai (atrodo, iš smiltainio).

Vartų pastato puošnumą, fasadų puošybos turtingumą rodo archeologo K. Meko patiltèje ir rūsyje prieš vartus rastos dekoro iš smiltainio nuolaužos. Tai, ardant vartų pastatą, nusimetę, nereikalingi akmens 


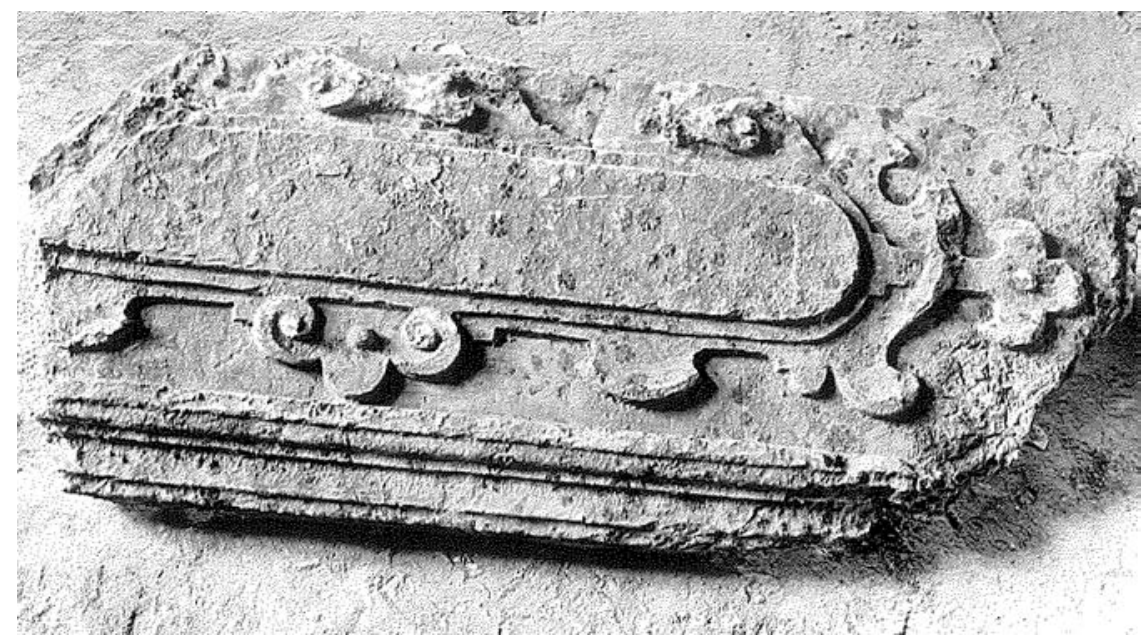

24.

Apvado ar frizinès juostos detalè, Mečislovo

Sakalausko nuotrauka, apie 1983

Detail of a surround or frieze

gabalai. Galima tik ịsivaizduoti, kiek jų išvežta i Astravą, užsienius ar ano meto statybas. Rūsyje tarp griuvenų rastos frizų [24 il.], karnizų, ịvairių neišaiškintos paskirties architektūrinių dekoro detaliu fragmentų, kolonos nuolauža. Labiausiai akcentuoti, matyt, buvo portalas, kartušai su Radvilų herbais, kiti idejjinị dekoro stilių išreiškiantys elementai. Kažkur, matyt, virš portalo buvo plokšte iš raudono akmens su lotynišku tekstu, kurios fragmentas surastas prie vartų. Daug rasta ir skulptūrinio dekoro iš smiltainio nuolaužų. Gražioji moters galvutė, kario portretas [25 il.], amūriuko kūnelio fragmentas, klostuotais drabužiais aprengtų figūrų fragmentai ir kitos detalès liudija itin aukštą vartus puošusio skulptūrinio dekoro meninį lygị. Neatsiliko, matyt, ir interjerų puošyba.

Rūmai. Naujos struktūros pilies projektas ir jo pobūdis. Pradèjęs naujujų pilies rūmų statybas J. Radvila jų užbaigti nespëjo, pradètą darbą po 1655-1660 m. įvykių tęsė B. Radvilos statybininkai. Perėmus Biržus, pilị ir čia prieš keletą metų sustojusias statybas, imtasi daug ką peržiūrèti, koreguoti, projektuoti iš naujo. Iškart po naujujų metų, $1662 \mathrm{~m}$. sausio 2 d., T. Spinovskis rašè, kad „tikrus naujos struktūros“ statymo darbus būtų 
galima pradèti vasarą. Turèta galvoje naujają pilies struktūrą - jei laiške būtų rašoma apie rūmų perplanavimą, vargu ar netrukus, kovo pabaigoje, būtų užsakomi J. Ulricho suprojektuoti sienų tvirtinimo gaminiai ar rūpinamasi magistro rengtais rūmų brèžiniais. Kardinaliau keisti rūmų architektūrą imta gerokai vèliau.

Rūmų statybos darbai vyko trūkstant medžiagų, darbo jëgos su pertraukomis dèl kitų, galbūt anuo metu svarbesnių, reikalingesnių, lengviau ịveikiamų pilies pastatų statybų. Rūmų statybą vis teko atidèlioti, o pradèti reikèjo nuo kelerius metus be priežiūros stovèjusių mūrų tvarkymo. Pilies atstatymą B. Radvila apsisprendè pradèti ne nuo rūmų, o nuo kareivinių 92 . Rūmų statybos darbai ịsisiūbavo tik po kelerių metų. 1660-1662 m. apsiribota uždengti iškilusias sienas nuo lietaus, suruošti statybines medžiagas. 1662 m. vasarą Vilniaus mūrininkai taisè išorines rūmų sienas ir mūrijo vidaus keldami jas iki vienodo su išorinėmis aukščio ${ }^{93}$, kol iš Kėdainių bus atvežti kareivinių brèžiniai. 1663 m., nors Radvila ne kartą buvo prašęs ${ }^{94}$, siuntęs T. Spinovskio projektą, kur parodyta, kaip tai reikia padaryti nė trupučio nuo projekto nenukrypstant ${ }^{95}$, rūmų skersinių sienų nespèta pradèti, buvo išmūryti tik jų pamatai ${ }^{96}$. Rūmuose $1663 \mathrm{~m}$. vyko daugiau parengiamojo pobūdžio darbai, bet buvo daromi ąžuoliniai rèmai (staktos?) rūmų langams $^{97}$. Statybos nepaspartëjo ir $1664 \mathrm{~m}^{98}$. Buvo vežama geležis, mediena, ruošiami ankeriai, atvežta daugiau nei 30 uolekčiu (apie $18 \mathrm{~m}$ ) ilgio balkių 99 .

Kiek spëjo sumūryti Jonušas Radvila? Dokumentuose nepasakyta, iki kokio aukščio spèjo pakelti pradètus statyti rūmus J. Radvila, bet juose jau buvo dalis langų, o langų angose - grotos. Išmūryta net dalis rūsių skliautų, juose jau buvo suformuotos durų angos, kurios buvo raitelių paplatintos, ir tik kai kurie langai be grotų, nes grotos išluptos ${ }^{100}$. Nežinia, kaip anais laikais neuždengus pastato stogo, jie buvo apsaugomi nuo permirkimo (prieš karą išmūryti rūsių skliautai turèjo atlaikyti ir kelis negandų metus). D. Kosciuška rūmus vadina pradètais statyti rūmais, o ne pradètomis 


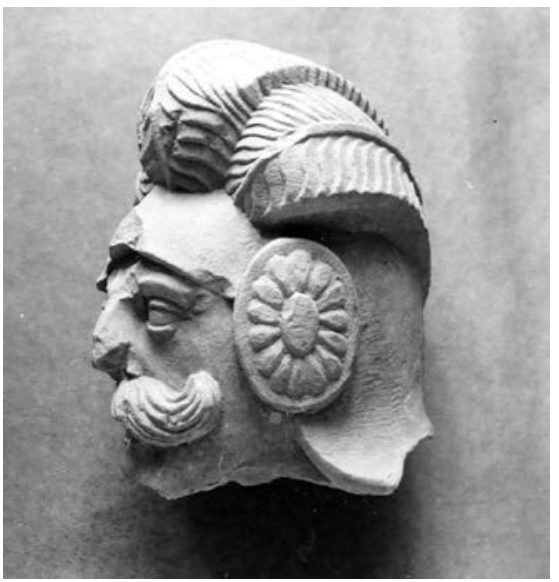

25.

Kario portretas, iki restauracijos

Portrait of a soldier. View before restoration

mūryti sienomis ar pan. Matyt, iškilę mūrai jau sudarè gerokai pakilusių rūmų ìspūdį. Aiškiausiai J. Radvilos mūrytų sienų aukštị nurodo B. Radvilos prašymas $1663 \mathrm{~m}$. liepos $21 \mathrm{~d}$. laiške - išgriovus sienoje mūrą patikrinti, ar virš rūmų viršutinių [paryškinta, $-E$. P.] langų yra įmūryti ankeriai. Metalo juostos buvo išdèstytos kiekviename aukšte per visą sienų ilgị virš sąramų, maždaug sienos viduryje. Gana storos, ankeriais sutvirtintos sienos turejjo atlaikyti netolygias sienų apkrovas, galimus judesius pamatuose, artilerijos šūvius ir pan. Trūkstant metalo juostų ar geležies joms nukalti, sustodavo rūmų sienų mūrijimas ir kone visa statyba. B. Radvilai perėmus rūmus, iš pradžių naudotasi prieš karą ruoštais magistro J. Ulricho ankerių sąrašais su juose nurodytais matmenimis.

Sugretinę kelias žinutes statytojų laiškuose, sužinome, kad J. Radvilos rūmų sienos iki 1655 m. buvo pakeltos labai nevienodai. 1665 m. liepos $4 \mathrm{~d}$., praejus daugiau nei trejiems metams nuo „naujos struktūros“ pilies projekto parengimo, pasidžiaugęs judančiais ị prieki darbais K. Karlikas nurodo iki pusès langų išmūrytus visus rūmų mūrus ir galerijų stulpus (ar tik nebus tada visame pastato perimetre priartèta prie J. Radvilos aukščiausiai iškeltų mūrų lygio). Nevienodai, tačiau aukščiausiai buvo iškilusios išorinès rūmų sienos. Tik kažkurių, greičiausiai dešiniajame rizalite, skersinių sienų pamatus spèta išmūryti iki 1663 m. rugsejjo 26 dienos. Kai kurios vidaus sienos buvo nė nepradètos, nors dalis jų jau buvo pakilusi kone iki 


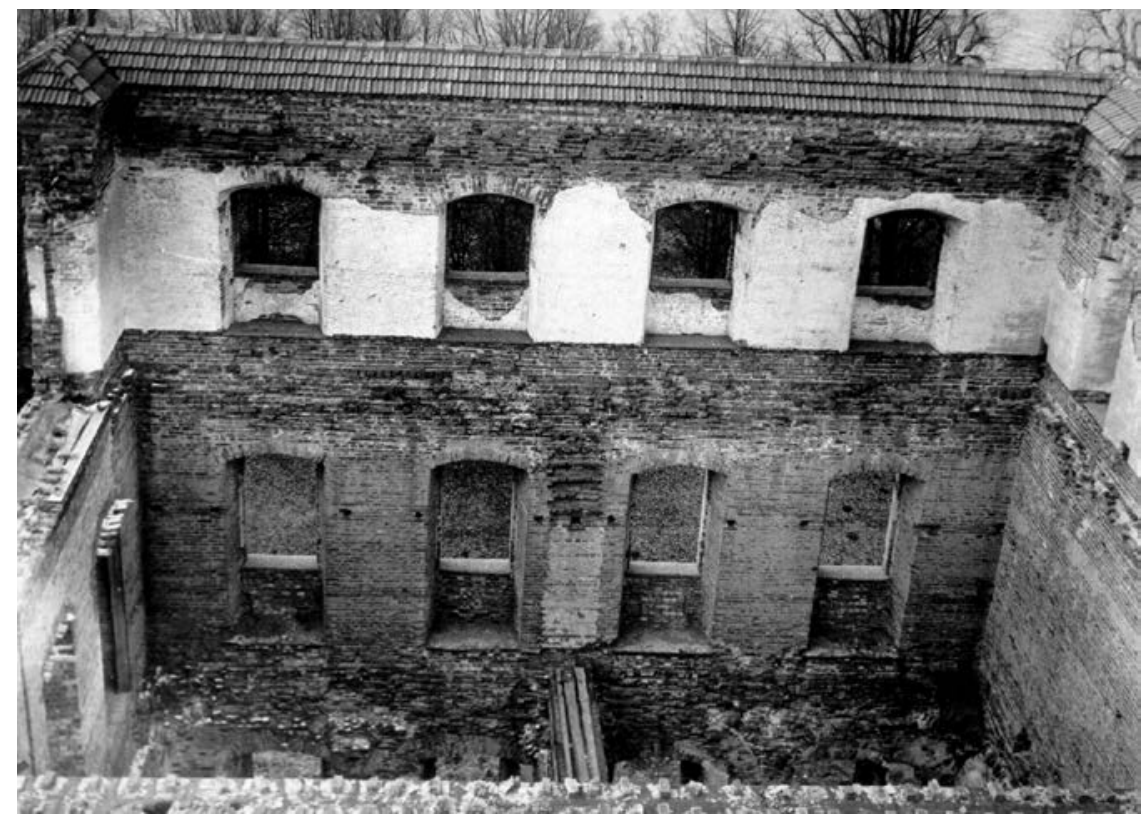

26.

Kairiojo rizalito P/V siena. Antro aukšto sienoje matosi viena iš mūrijant išorines sienas suformuotų jungčių skersinėms sienoms prijungti. Skersinė siena buvo pakelta tik iki pirmo aukšto viršaus, Mečislovo Sakalausko nuotrauka, 1981
South-western wall of the left avant-corps

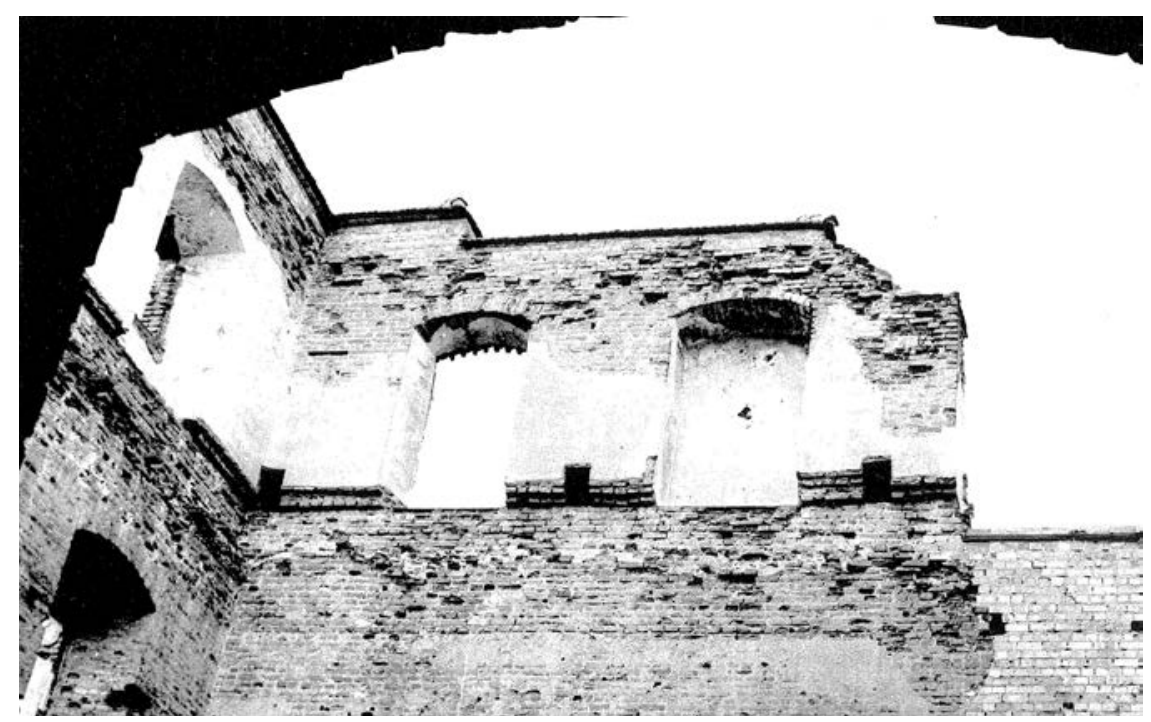

27.

Siena tarp kairiojo rizalito ir laiptinės. Nuotraukoje užfiksuota dviejų statybos laikotarpių mūrų riba ir storesnès nei apačioje rizalito trečio aukšto sienos, Evaldo Purlio nuotrauka, 1974
Wall between the left avant-corps and the stairway. The photo shows the boundary between two construction periods and the walls of the second floor of the avant-corps being thicker than at the bottom 
išorinių sienų lygio. Net $1667 \mathrm{~m}$. balandžio pabaigoje meistrai su padejejejais dar mūrijo rūsius.

Viena iš statybų sekos savybių, kurias galima įžvelgti ir statytojų laiškuose, ir natūroje, - vidinès kapitalinès sienos mūrytos ne kartu su išorinėmis. Iš pradžių formuoti išoriniai rūmų ar jų dalių (rizalitų, centrinès rūmų dalies) kontūrai. Vidinėms sienoms numatytose išorinių sienų vietose suformuotos vadinamosios mūro jungtys. Prie šių jungčių vẻliau jungėsi tiek Jonušo, tiek Boguslavo Radvilų mūrininkai. Atsisakius kai kurių planuotų sienų, jungtys užlygintos skiediniu [26 il.].

Natūroje kelios mūrų sandūros rodo dviejų statybos etapų ribą virš antro aukšto langų sąramų. Vienoje iš kairiojo rizalito sienų apie 15 plytų eilių žemiau buvusio perdangos sijų lygio matoma aiški horizontali dviejų sienos mūrijimo etapų riba. Abipus ribos aiškiai matomas mūrininkų braižo skirtumas [27 il.]. Mūrų riba pasiekia patalpos kampą, pereina ì kairiaja sieną, kur už 1,0-1,5 m keliomis eilèmis pakyla, nueina rūmų kampo link. Net nuotraukoje aiškiai matyti, kaip ši riba dešinėje sienoje, priartėjusi prie išlikusio mūro ribos, staigiai leidžiasi žemyn. Galima spėti, kad čia yra riba, nuo kurios èmė kilti B. Radvilos mūrai pietiniame kairiajame rūmų gale. Atkreiptinas dèmesys, kad mūrus abipus ribos skiria nemažas laiko tarpas. Riba nurodytose sienose išliko gerai matoma tik dèl to, kad jų ribojama salè iki pat 1978-1986 m. restauracijos taip ir liko nenutinkuota. Kairiojo rizalito kontūrą formuojančios sienos čia tikrai buvo iškilusios virš antro aukšto langų. Kitose pastato dalyse tokių aiškių ribų nèra, didelę dalį šių sienų paviršių dengė autentiškas rūmų statybos meto tinkas.

\section{Žemutinès fasadu dalies architektūra - igyvendinta J. Ulricho} rūmu projekto dalis. Iki $1655 \mathrm{~m}$. buvo jau suformuotas pagrindinių sienų tinklas, kuris, nežiūrint nemažų vèlesnių architektūros pakeitimų, išliko nedaug pakitęs. İkomponuotos laiptinės. Nors ne visos išorinės sienos buvo išmūrytos iki antro aukšto viršaus, tačiau iki $1655 \mathrm{~m}$. jau buvo beveik suformuota fasadų dviejų aukštų architektūra. Buvo suformuota didelè dalis langų angų, išmūrytos ar pradètos mūryti horizontalios fasadus skaidančios juostos, kampiniai rustai, pradèti formuoti langu apvadai ir pan. Nežinia, kiek, bet jau buvo pradėta arkadų galerija pagrindiniame fasade, jau buvo pamatas po ja.

Evaldas Purlys

Biržu pilies statinių architektūra ir jos raida 
Keisti rūmų architektūrą sumanyta netrukus po pilies atsièmimo, tačiau J. Radvilos rūmų fasadų architektūros ir suplanavimo struktūros igyvendinimas jau buvo gerokai įsibėgèjęs, ne taip lengvai pakeičiamas. Atrodo, jau vos susipažinęs su J. Ulricho projektu, T. Spinovskis užsimojo pakeisti rūmų pastato viršutinès dalies architektūrą. Norint tą padaryti, būtų reikėję nemažai išgriauti, perstatyti, tačiau išlikusiuose mūruose aiškių griovimų, didelių perstatymų požymių neužfiksuota. Nè viename dokumente nekalbama apie rūmų perplanavimą ar padarytų vidaus struktūrų ardymus. Nieko nesakoma ir apie sienų, išskyrus lietaus ir šalčio paveiktų mūrų, ardymus. Galima buvo koreguoti tik nepastatytų vidaus sienų išdèstymą ar aukštį, fasadų viršutinès dalies architektūrą. Akivaizdžius pirmuosius, atrodo, neesminius projekto pakeitimus pamatysime laiptinių architektūroje.

Laiptiniu perprojektavimas. T. Spinovskis $1661 \mathrm{~m}$. spalio pradžioje, atvykęs ị Biržus, „numatè rūmų laiptines ir apmetė būsimų fasadų struktūrą"101. Laiptinių mūro tyrimai rodo, kad ne vietos laiptinèms numatymas, o jau pradètų formuoti laiptinių patobulinimas, pertvarkymas buvo vienas svarbiausių naujosios rūmų architektūros struktūros elementų.

Pažiūrèkime į kitą užfiksuotos sienos [žr. 27 il.] pusę, į abi kairiosios laiptinès sienas - toje pat sienoje, tik kitoje jos pusejje po žemutine laiptu aikštele matome nedidelę pusapvalę nišutę, o virš jos gražiu apvadu apjuostą, taip pat pusapvalę nišą su užmūrytos ankstesnès nišos angokraščiais apačioje. Žemutinè ir ankstesnioji niša formuojant viršutinę užmūryta, nuardyta šios sąrama [28 il.]. Dar ryškiau šie pakeitimai matomi vienoje iš dešiniosios laiptinès sienų [29 il.]. Čia išlikusi ir pirminès nišos sąramos pradžia. Akivaizdžai matome du statybos etapus - viršutinè didžioji niša suformuota B. Radvilos statybų laikotarpiu, ankstesnioji skirtina J. Radvilos statyboms.

Abiejų laiptinių šonines sienas ir jose buvusias pirmines nišas formuoja to paties tipo mūras kaip ir išorinèje sienoje - laiptinių sienos ir iki projekto korektūros buvo tose pat vietose, laiptinès tokio pat pločio. Visos trys abiejų laiptinių kontūrus formuojančios sienos pradètos mūryti iki B. Radvilos statybų. Ankstesniujų nišų formos, jų įkomponavimas rodo, kad dabartinių laiptinių vietose ir pagal pirminị sumanymą turèjo būti laiptinès, o tai reiškia, kad vieta laiptinèms parinkta, rūmų struktūra sukurta 


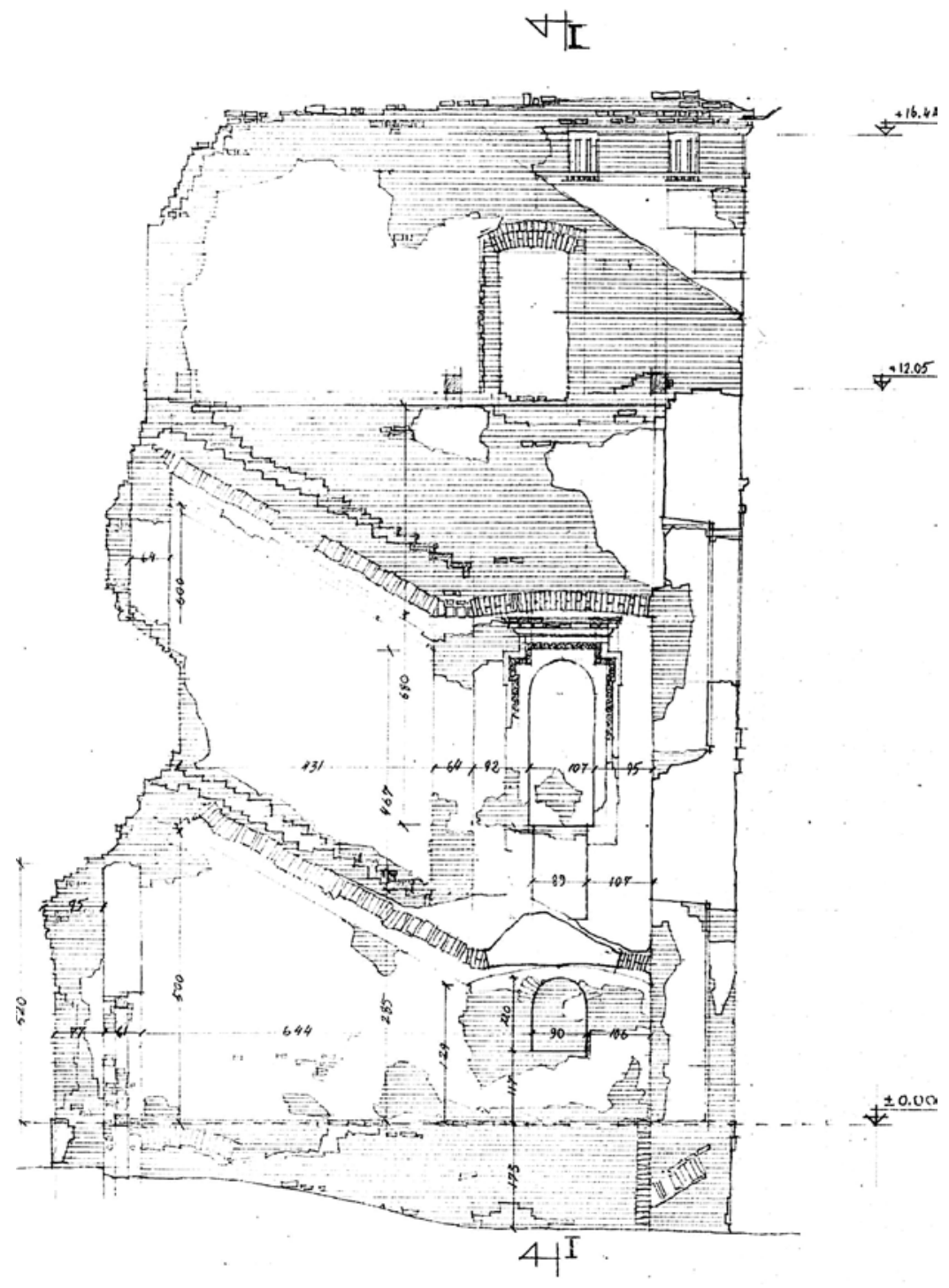

28.

Nišos kairiosios laiptinès pietinėje sienoje. Po žemutine laiptų aikštele matoma užmūryta nedidelè pusapvalè nišutè, o virš laiptų aikštelès gražiu apvadu apjuosta, taip pat pusapvalè niša. Po apvadais puošta niša yra likę abu ankstesnès nišos šoniniai angokraščiai. Trečio aukšto lygyje užfiksuotas centrinès rūmų dalies stogo atspaudas rizalito sienoje, Algimanto Umbraso apmatavimų brèžinys, apie 1955
Niches in the southern wall of the left stairway

Evaldas Purlys

Biržu pilies statiniu architektūra ir jos raida 


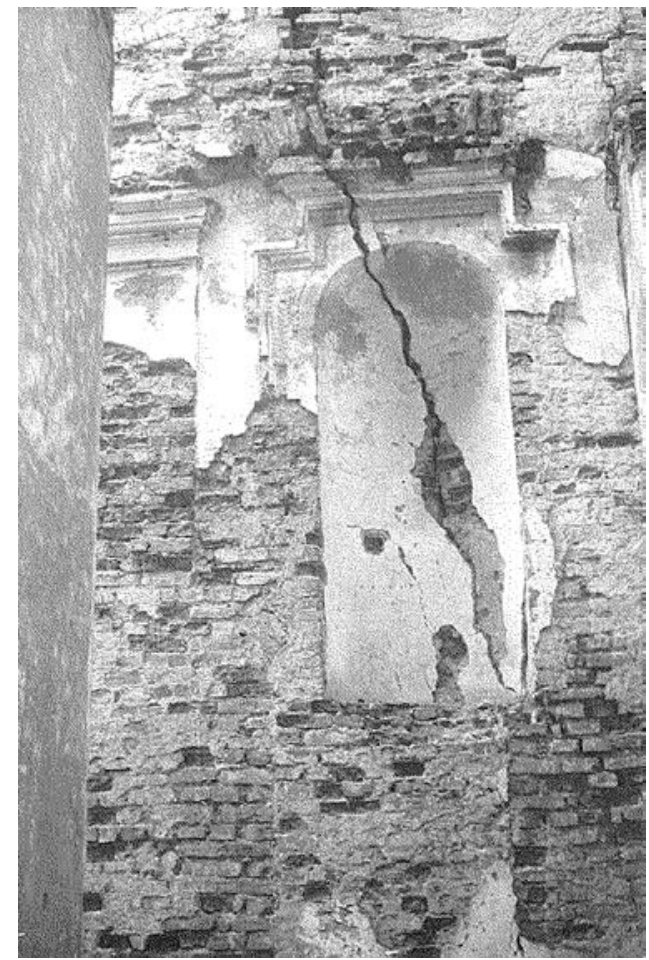

29

Niša dešiniosios laiptinès pietrytinèje sienoje. Po apvadais puošta niša yra likę abu ankstesnès nišos šoniniai angokraščiai, dalis sąramos, Evaldo Purlio nuotrauka, 1974

Niche in the south-eastern wall of the right stairway

J. Radvilos statybu laikotarpiu pagal magistro J. Ulricho projektą. T. Spinovskis pakeitė laiptų maršų ir abiejų laiptinių centrinių sienų komponavimą bei architektūrą. Šie pakeitimai galejjo būti ta $1662 \mathrm{~m}$. T. Spinovskio „naujoji struktūra“ rūmuose. Vienas gana aiškus pirminio sumanymo korektūros laiptinèse ženklas prieš 1978-1987 m. restauraciją matèsi dešiniojoje laiptinèje [30 il.], čia mūrijant naujas laiptinès konstrukcijas teko užmūryti anksčiau mūrytoje sienoje suformuotą durų angą.

Apie kokị J. Ulricho suprojektuota rūmu architektūros elementa sako vienšlaitis stogas? Ne kartą minètame $1664 \mathrm{~m}$. sausio $20 \mathrm{~d}$. laiške B. Radvilai T. Spinovskis sukritikavo rūmų vienšlaičio stogo autorių, kuris mirusiam kunigaikščiui [Jonušui, - E. P.] tą stogą nupiešè. Irodinëjo, kad vienšlaitis stogas tokiam plačiam pastatui būtų per žemas ir per plokščias. Siūlè supaprastinti ir seno projekto rūmų karnizą - naujam karnizui mažiau reikèsią geležies, paprastesnis meistras ${ }^{102}$. Gali būti, kad pirmuosius naujos 
stogo formos eskizus T. Spinovskis parengė dar $1661 \mathrm{~m}$. spalio pradžioje, kai atvykęs i Biržus apmetè būsimu fasadu struktūrą.

Kritikuodamas vienšlaitị stogą T. Spinovskis siūlè pakeisti ne tik magistro J. Ulricho suprojektuoto vienšlaičio stogo formą, bet ir neišvengiamai su stogo forma susijusị rūmų viršutinio aukšto architektūrinị sprendimą. Kaipgi jis atrodė? Nesant J. Ulricho projektuotų rūmų architektūros aprašymų, nelikus jo darytų brèžinių, neliko ir žinių apie J. Radvilos pradètų statyti rūmų viršutinès dalies architektūrą. Tačiau galima spėti, kad viršutinè dalis galèjo turèti tam laikui būdingą puošnų atiką. J. Ulrichas projektuodamas vienšlaiti atviroje edvėje stovinčių rūmų stogą be atiko negalėjo apsieiti. Visu pirma jis turèjo dengti kitoje rūmų pusėje iškilusią vienšlaičio stogo konstrukciją. Taip pat kažkaip reikėjo uždengti vienšlaičio stogo konstrukciją ir iš šonų. Bandant ịsivaizduoti, kaip tai galejo būti padaryta, reikia pasitelkti rūmų planą, tačiau reikia atkreipti dėmesị, kad rūmų tūris susideda iš trijų dalių ir toks jis sumanytas dar projektuojant pirminị rūmų architektūros variantą. Jau tada buvo numatyta galerija pagrindiniame fasade. Žinia apie vienšlaitị stogą veda ị žymiai sudètingesnic, nei atrodo iš pirmo žvilgsnio, J. Ulricho siūlytą rūmų viršaus architektūrinị sprendimą.

Dèl rūmų tūrio suskaidymo vientisas vienšlaitis stogas negalëjo dengti viso pastato. Jis galèjo būti tik virš rūmų centrinès dalies su atiko sienute kitoje vienšlaičio stogo pusèje, atkarpoje tarp rizalitų. Žiūrint i rūmų tūrių išdėstymą plane, matosi, kad rizalitus, nors jie buvo tokio pat aukščio kaip centrinè rūmų dalis, turèjo uždengti atskiri stogai, tačiau vienšlaičių stogų virš rizalitų tiesiog neįmanoma įkomponuoti. Suprojektavus atiko sienutę rūmų centre, be atiko sienučių negalima suprojektuoti ir stogu virš rizalitų - vienšlaičio stogo konstrukciją dengianti atiko atkarpa negalèjo nutrūkti prie rizalitų. Bet kuriuo atveju tarp vienšlaičio stogo tūrio ir rizalitų turèjo būti atitvara su virš vienšlaičio stogo matoma dalimi. O tai dar viena atiko sienutè. Kiek čia belieka, kad įsitikintume, jog atikas nuo centrinès rūmų dalies turejjo pereiti ir ant visų kitų abiejų rizalitų sienų tai renesansiniams atikams būdingas sprendimas, kai jie pastatomi ant visu keturių iš visų pusių apžvelgiamo kontūro sienų. Iš visų pusių atikų apjuosti dideli rizalitų stogai galèjo būti tik daugiašlaičiai. 


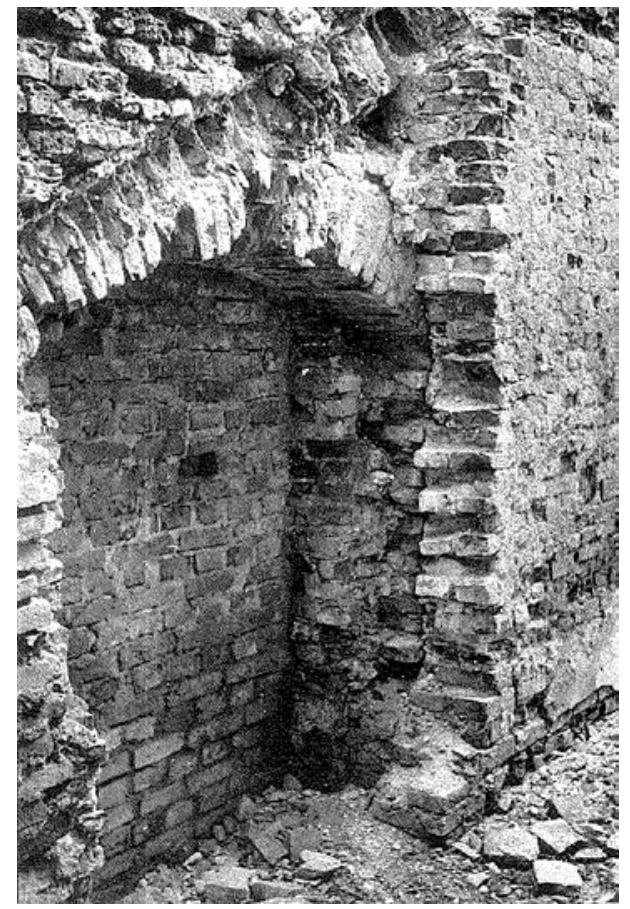

30

Buv. durų anga pusrūsyje, dešiniosios laiptinès pietrytinėje sienoje. Užmūryta formuojant Teofilio Spinovskio projektuotos laiptinès skliautą, Evaldo Purlio nuotrauka, 1974

Former door opening in the basement, the south-eastern wall of the right stairway. It was bricked up while building the vault of the stairway designed by T. Spinowski

Atsižvelgdami ị išdèstytus samprotavimus galime bandyti rekonstruoti J. Ulricho projektuotą rūmų viršaus vaizdą. Pastato centre, tik nežinia, kurioje pastato pusėje, tarp rizalitų atikų turejjo matytis stogas. Galimi abu šio stogo krypties variantai. İkomponavus atiką virš užpakalinio rūmų fasado, vienšlaitis stogas dengtų ir arkadą, o stogas ant tokio plataus pastato būtų labai ilgas ir aukštas. İkomponavus atiką priekyje, jis turèjo kilti ne virš priekinès sienos su arkomis, o virš sienos arkadų gilumoje. Arkadą šiuo atveju būtų dengęs atskiras stogas.

Dèl didelio rūmų pločio vienšlaitis stogas virš rūmų centrinès dalies abiem atvejais vis tiek turèjo iškilti gana aukštai - J. Ulrichas tai matydamas tikriausiai stengèsi kuo labiau ji pažeminti. Ir susilaukė kritikos. Kritikos smaigalyje, matyt, buvo ne tik vienšlaitès stogo dalies konstrukcija, bet ir patys iš mados jau išeinantys atikai. Kaip turejo atrodyti atikų architektūra ir kaip atikų supami stogai buvo sukonstruoti, palikime ateičiai, kai rasime daugiau žinių. 
Pirmieji atikai Abiejų Tautu Republikoje pasirodė Krokuvoje gelumbės pirkliu pastate (Sukiennicy) $1557 \mathrm{~m}$. ir virš Poznanės rotušès 1561-aisiais. Abu šie pastatai stovi atvirose, iš visų pusių juos supančiose erdvėse. Atikai apjuosė visą šių pastatų perimetrą. XVI a. viduryje ateinantys ì madą atikai ėmè puošti renesansinių pilių tūrius, vainikavo rotušes ir gyvenamus namus, bažnyčių ir miestų vartų bokštus. $O$ už iš Italijos atėjusių atikų buvo ịrengti svetimi mūsų kraštų klimatui stogai, nukreiptais i pastatų vidurị šlaitais. Siekiant nors kiek itališką stogą pritaikyti prie šiaurès klimato, didesnio ploto pastatuose stogas imtas dalyti i kelias ị pastato vidų nukreiptų stogų sekcijas, šlaitams sekcijose stengtasi suteikti kuo didesni nuolydi, imtasi kitų techninių apsaugos nuo vandens ir sniego priemonių. Vanduo tokiu stogų šlaitų apačioje įrengtais loviais per angas atike buvo išleidžiamas lauk. Už renesansinių atikų slypinčių stogų bangas šiandien galime suskaičiuoti pagal fasaduose nuleistus lietvamzdžius. Anksčiau, kol lietvamzdžių nebuvo, vanduo, ištekejjęs iš lovio, krisdavo žemyn. Kad atitrauktų vandeni kiek toliau nuo fasadu plokštumos, buvo skirti prie lovio galo pritvirtinti stamboko skerspjūvio vamzdžiai su dekoratyvinėmis įvairių gyvūnų, dažniausiai drakonų galvomis ant vamzdžiu galo. Atikai ne tik slèpé pastatų stogų konstrukcijas, ne tik puošniomis savo formomis vainikavo pastatus, bet padejjo jiems saugotis nuo gaisrų. Gynybiniame statinyje atikas, matyt, turëjo apsaugoti ir medines stogo konstrukcijas nuo šūvių, Lietuvoje turime tik vieną autentišką tebefunkcionuojantị i pastato vidurị nuleistais šlaitais stogą - už Vilniaus Aušros vartų atiko [31 il.].

Atikai suvaidino svarbų vaidmeni XVI-XVII a. Respublikos miestų architektūrinëje išraiškoje. Tačiau jo triumfo žygis nepalietẻ stogų su i vidų nukreiptais šlaitais - sniegas čia gulèjo ilgai, latakai užsikimšdavo, puvo medinės konstrukcijos, vanduo užliedavo patalpas. XVII a. pirmoje pusėje stogai su i vidų nukreiptais šlaitais (Lenkijoje) išvis išnyko ${ }^{103}$. B. Radvilos statybos peržengė ị antrą XVII a. pusę. Pasikeitę skoniai, mados, naujo architekto pasiūlymai skatino ieškoti naujo rūmus vainikuojančių tūrių silueto.

Rümu statybu ir projekto korektūru issibègëjimas. Lemtingi rūmų architektūros bei jų tūrių pakeitimai padaryti 1664 m., kai buvo atsisakyta J. Ulricho projektuoto rūmų viršutinės dalies ir stogo sprendimų,

103 Przemysław Trzeciak, 1000 tajemnic architektury, Warszawa: Nasza księgarnia, 1988, p. 165 . 
taip pat 1665 m., kai buvo apsispręsta trečią rūmų aukštą statyti tik ant rizalitų. Vèliau, 1666 m., stogo aukščio, karnizo profilio koregavimas tebuvo 1664, 1665 m. pakeitimų detalizacija, korektūra.

1665 m. pavasarị vadovauti statyboms ị Biržus nusiųstas S. Arciševskis „patarè vasarą [baigti, $-E$. P.] išmūryti rūmų rizalitų sienas“104. Dèl rūmų statybos susitarta su magistru Georgijumi Ertliu. Netrukus atvykęs pastarasis pasiūlè vietoj balkių perdengimų mūryti skliautus ${ }^{105}$. Matyt, turèta galvoje pirmo aukšto skliautus - visos pirmo aukšto patalpos skliautuotos. Dalis rūsių skliautų išmūryta dar J. Radvilos.

1665 m. gegužès mėnesi rūmus mūrijo 5 mūrininkai ${ }^{106}$, liepos pradžioje visi rūmai iki pusès langų išmūryti kaip ir stulpai galerijoje“107, rugpjūčio pabaigoje mūryti rūsių skliautai, ankeruotos ${ }^{108}$ viršutinio aukšto sie$\operatorname{nos}^{109}$. Iš laiško galima suprasti, kad tik 1666 m. pradžioje antro aukšto viršu pasiekè visos, taip pat ir vidinès rūmų sienos. Iki $1655 \mathrm{~m}$. dalis sienų buvo pakilusi iki šio lygio arba arti jo. Sezonui baigiantis B. Radvila įsakè ruošti medžiagas, kad rūmus būtų galima užbaigti ateinantị pavasarịi110.

1665 m. kurị laiką nežinota, ar statyti šoninius paviljonus, ar statyti trečią rūmų pastato aukštą. Neaiškumų kilo dèl to, kad pilies komendantui (K. Karlikui) B. Radvila rašè pradèti statyti abu šoninius paviljonus ir vidurinę pastato dali, o S. Arciševskiui kalbejjo apie trečią aukštą ${ }^{111}$. Neplanuoto trečio aukšto požymiai matomi natūroje, antro ir trečio aukšto mūru sandūroje. Senose šių sienų nuotraukose matome, kad čia kairiojo rizalito mūrai pakilę virš trečio aukšto perdangų lygio ne suplonėja, o atvirkščiai staiga pastorèja daugiau nei per pusę plytos [žr. 27 il.] - kraštines antro aukšto perdangos sijas kone per visą sijos plotị buvo uždengęs virš jų kylantis mūras. Panašiai išmūrytų sienų yra ir dešiniajame rizalite. Matome vieną požymių, rodančių, kad J. Radvilos pradèti statyti rūmai buvo projektuoti dviejų aukštų, virš kurių turèjo kilti atiko mūrai.

104 Stasys Pinkus, op. cit., 1971, p. 268.

105 Ibid., p. 269.

106 Ibid., p. 268.

107 Deimantas Karvelis, op. cit., 2006, p. 23.

108 Metaliniai sienų tvirtinimo ankeriai ịprastai dedami mūro sluoksnyje tarp langų sąramų ir perdangos sijų.

109 Stasys Pinkus, op. cit., 1971, p. 268.

110 Ibid., p. 269.

111 Deimantas Karvelis, op. cit., 2006, p. 33. 


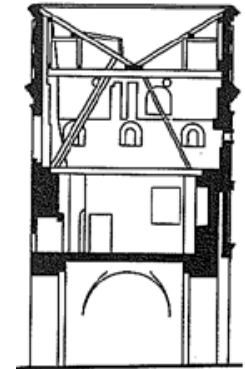

31.

Aušros vartai Vilniuje. Skersinis pjūvis su stogo konstrukcija, in: Lietuvos architektūros istorija, t. I: Nuo seniausiu laiku iki XVII a. vidurio, Vilnius: Mokslas, 1987, p. 216

Gate of Dawn in Vilnius. Cross-section with the roof construction

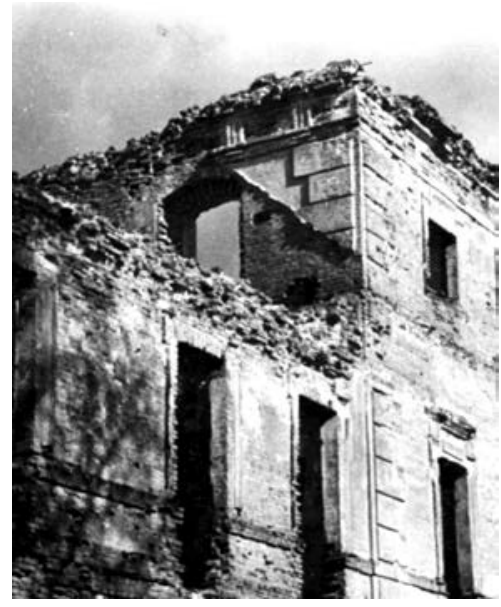

32.

Stogo atspaudas kairiojo rizalito sienoje. Virš atspaudo po karnizu yra išlikę triglifai. 1950-1955 m. nuotrauka. Rūmų centrinès dalies stogo linija užfiksuota ir 28 il.

Imprint of the roof in the wall of the left avantcorps. Triglyphs have survived above the imprint under the cornice

T. Spinovskio suprojektuoto stogo korektūra. B. Radvilos statybu laikotarpio pabaiga. Susilaukè kritikos ir T. Spinovskis. Dar vieną korektūrą pasiūlè magistras stalius Zyvertas Holzenas - stogas per daug plokščias, žemas ir sunkus, todèl ji reikia paaukštinti per dvi uolektis (apie 120-125 cm), be to, T. Spinovskis „pamiršęs pažymèti karnizo matmenis“112. B. Radvila pasirinko rūmų variantą su triaukščiais šoniniais paviljonais, o sureagavęs į Z. Holzeno kritiką, nurodè stogą daryti 18 uolekčių aukščio ${ }^{113}$. Natūroje abiejų rizalitų mūruose išliko stogo žymès, kurios pakèlè stogo kraigą maždaug i i B. Radvilos nurodytą aukšti [32 il.]. 1978-1986 m. restauruotų rūmų stogas montuotas derinantis prie šių žymių.

Pasak S. Pinkaus, 1666 m. vasarą sparčiai mūrytos rūmų vidinès sienos. Nuo balandžio 8 d. iki liepos 31 darbams vadovavo G. Ertlis ${ }^{114}$, 1667 m. Biržuose tebedirbo stalius Z. Holzenas, konstravęs stogo fermas. Apie rugsejjo 22 d. stogas buvo užbaigtas. Dirbta ir visus 1668- 1669 metus. Gamintos rūmams durys, langų rèmai, grotos, tinkuoti rūmų rūsiai ${ }^{115}$ ir pan. 
Iki pat mūsų laikų liko nenutinkuoti rūmų centrinès dalies ir pietinio rizalito rūsiai. Natūroje daugelio pirmo aukšto langų angokraščiuose rasta metalinių grotų, o visuose languose - langų staktų atspaudų.

Rūmų stogą ąžuoliniais gontais pavyko uždengti dar 1667 m. rugsẻjį ${ }^{116} .1669$ m. lapkričio 9 d. K. Karlikas rašè B. Radvilai, kad „rūmų rizalitai tuo metu jau uždengti čerpèmis“, laiške jau kalbama apie vėjarodžių ir Radvilų herbų paauksavimą. Smulkiai aprašoma, kokie turi būti ant rizalitų stogų viršūnių užkelti ereliai117. Aplink stogo pakraštį ruoštasi įtaisyti švino latakus ir žioteles lietaus vandeniui nuo stogo nuleisti ${ }^{118}$. Šie gaminiai paprastai montuojami prieš klojant čerpes, jie galejjo būti sumontuoti, o neišlikti dèl po rūmų sprogdinimo $1704 \mathrm{~m}$. kilusio gaisro - išsilydyti, sudegti degant rūmams. 1669 m. gruodžio 31 d. mirè B. Radvila. Nors stogas ir užbaigtas, rūmuose liko neatlikta ịvairių mūro darbų, net rūsiai nebaigti mūryti.

Rūmu suplanavimas, architektūra, kambariu paskirtys. Rūsiai [33 il.] buvo skirti ịvairaus pobūdžio pagalbinei paskirčiai. Daugelyje jų îrengti židiniai patalpoms apšviesti. I̦ rūsius nusileidžia abeji rūmų laiptai. Dar vienas ịejjimas ị rūsius ịrengtas po išoriniais laiptais ị pirmo aukšto galeriją. Šis įejjimas sudare galimybę rūsiuose ịrengtoms patalpoms funkcionuoti atskirai nuo rūmų gyvenimo. Šiais laiptais nusileidus ị rūsị buvo patenkama ị didelị po rūmų galerijomis ịrengtą koridorių, kuriuo buvo galima produktus, gaminius ar kokius buities reikmenis paskirstyti į bet kurią rūmų pagalbinių patalpų rūsiuose zoną. Šios taip pat gerokai skyrèsi.

Pagrindiniai ièjimai ị rūmus du - iš pirmo aukšto galerijos [34 il.] per priemenes prie laiptinių galima buvo eiti arba ị kairiojo rizalito sales, arba ị gyvenamąsias ir svečių patalpas dešiniajame rizalite, kilti ị valgomąjị. Iš antro aukšto priemenių prie laiptinių buvo galima išeiti ị antro aukšto galeriją. Aiškiausiai skaitoma kairiojo rizalito ir centrinès rūmų dalies struktūra. Kairiajame rizalite, dabar veikiančios bibliotekos pusejje, buvo didžiưjų reprezentacinių rūmų salių zona, čia platesni laiptai, prie kambarių nèra tualetų. Viename Liudvikos Karolinos statybų laikotarpio dokumentų šie laiptai pavadinti didžiaisiais ${ }^{119}$. Nuo priemenės šių laiptų maršai ị rūsi atskirti pertvara su durimis - nesvarbu, kad durys dvivèrès ir labai plačios. Kairiajame rizalite buvo net penkios didelès salès - viena pirmame aukšte, 
po dvi antrame [35 il.] ir trečiame [36 il.] aukštuose. Puošniausios, aišku, turèjo būti didžiosios antro aukšto salès, tačiau abi jos iki pat 1704 m. nebuvo net nutinkuotos.

Centrinëje rūmų dalyje ir dešiniajame rizalite visos patalpos gerokai mažesnès nei kairiajame rizalite, prie pirmo, antro ir trečio aukštų patalpų pietvakarinèje rūmų pusėje yra tualetai - čia buvo aiškiai išreikšta gyvenamoji rūmų zona. Tualetai įrengti pietvakarinès (Agluonos pusèje) sienos storyje prie dešimties rūmų patalpų. Gyvenamosios zonos buitiškumą pabrèžia ir per visus aukštus, nuo pat rūsių kylanti lifto šachta, siauresni nei kairėje pusėje laiptai. Šachtoje numatytas ir galbūt buvo ịrengtas keltuvas.

Daugiausia klausimų liko dešiniojo rizalito suplanavimo schemoje. Po juo sprogo vienas iš parako užtaisų. Čia sudètingesnis patalpų išdèstymas, mažesni kambariai. Gali būti, kad šio rizalito centre, kiekviename aukšte buvo nedideli, statmeni priemenėms koridoriukai, apie kuriuos grupavosi patalpos. Panaši ị koridoriuką patalpa yra rūsyje, tačiau viena iš jo sienu gerokai plonesnè nei kitos, suabejota, ar ji kilo aukščiau. Nieko įtikinamo apie galimą šios sienos tęsinị pirmame ar antrame aukštuose tyrèjai neįžvelgè ir suvirtusiuose sienų luituose. Vienas iš šių luitų rodė antro aukšto priemenèje dešiniojo rizalito sienoje buvus židinị ir krosnies pakurą šalia, kaip ir sienoje kitoje priemenès pusėje. Dèl neaiškumų šios rūmų dalies suplanavime nesiryžta formuoti koridoriukų ir restauruojant rūmus. Neatstatyti ir šioje rizalito zonoje buvę skliautai. Trečiame aukšte vakariniame rizalito kampe būta gan didelès salès. Ar tik ne čia būta valgomojo, kuriuo taip rūpinosi B. Radvila? Daugiau žinių apie patalpų paskirtis, jų vidaus architektūrą teikia dokumentai iš Liudvikos Karolinos statybų laikotarpio.

\section{Pilis Liudvikos Karolinos Radvilaitès statybų laikotarpiu}

1669 gruodžio 31 d. mirus B. Radvilai, neliko pilies šeimininko, energingo, pilies reikalais besirūpinančio statytojo. Jo ekonomai ìsakè statybos darbus nutraukti, amatininkus atleisti, o statybai priruoštas medžiagas parduoti. K. Karlikas aprašo pilies pastatų būklę: „kiauras arsenalo stogas, patrankas ir kitoki inventorių tenka nuo lietaus dangstyti“120. Darbai kuriam laikui pilyje nutrūko. Atnaujinti jie buvo daugiausia rūmų 


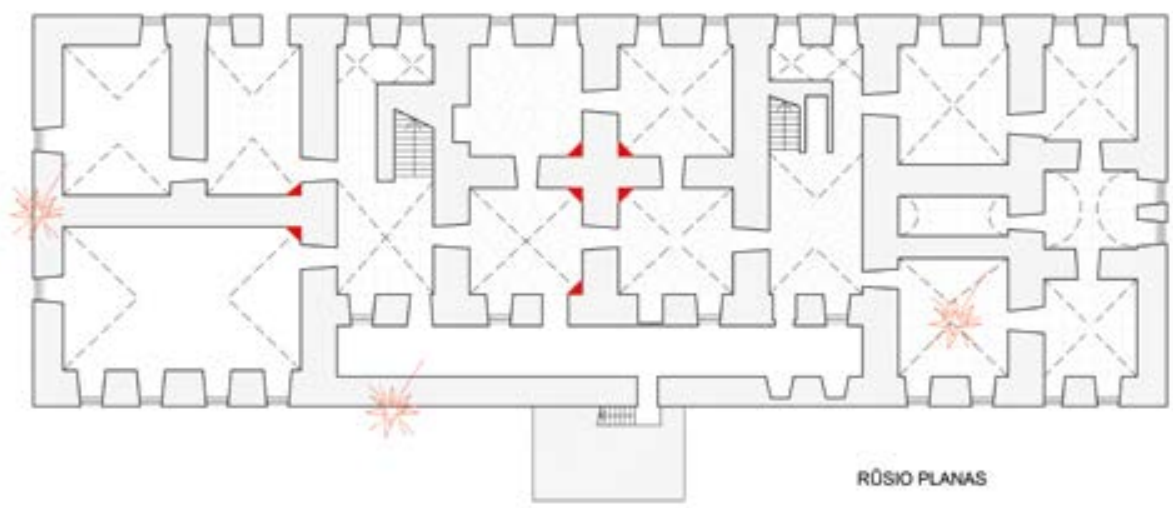

33.

Pusrūsio planas

Basement plan

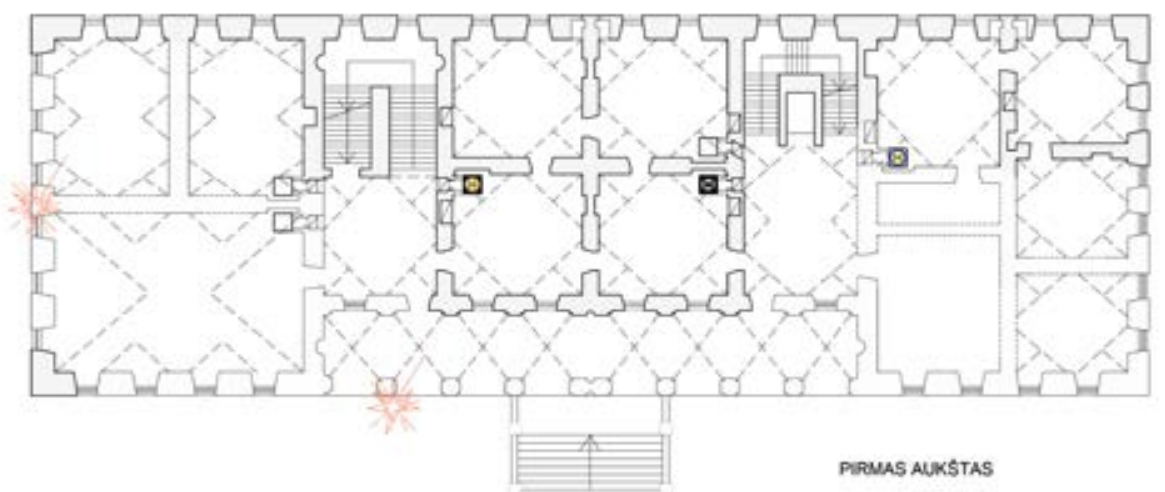

34.

Pirmo aukšto planas su židiniais ir krosnimis

Ground-floor plan with fireplaces and stoves 


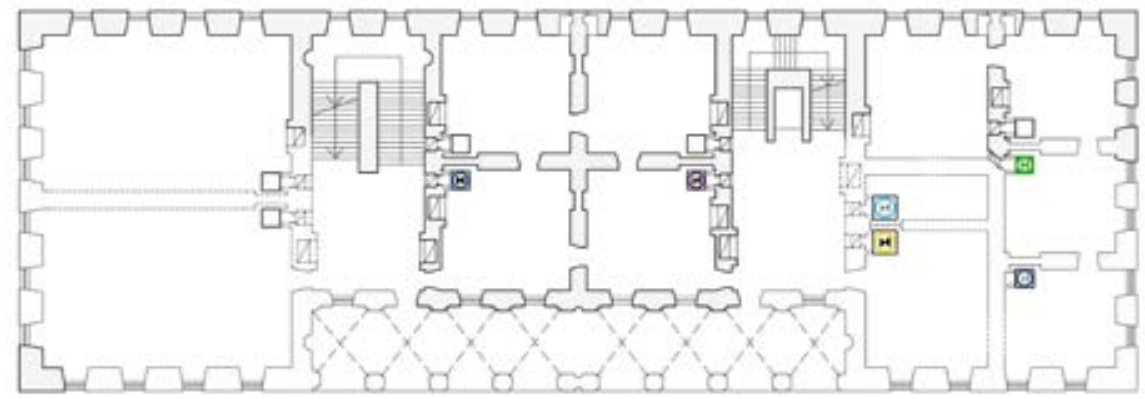

ANTRAS AUKSTAS

35.

Antro aukšto planas su židiniais ir krosnimis

First-floor plan with fireplaces and stoves

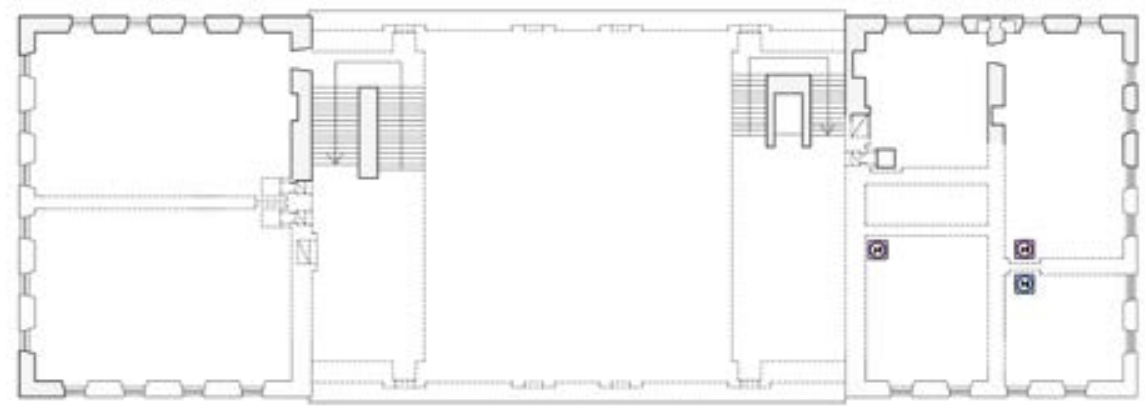

TRECLAS AUKSTAS

36.

Trečio aukšto planas su židiniais ir krosnimis

Second-floor plan with fireplaces and stoves

\section{SUTARTINIAI ŽYMĖJIMAI}

$\square$ ISLIKE AUTENTS\$KK ROMY MORN

RESTAURUOT, ZINOM ARCHTEKTORINEA ELEMENTAI

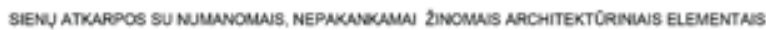

- - SKLINTAN

$\square$ GRINDYS IS LAUKO AKMENY
$\square$ GRINOYS IS KERAMKINUY PLTELY

(D) IS ARCHELOGINES MEDLAGOS ZNONOS KROSANS IR N SPALVINLW DERINLW

NUMANOMA KCAOSNIY VETA

/ KAMPNIS LIONYS 
viduje vadovaujant B. Radvilos dukters Liudvikos Karolinos igaliotiniams. Labiausiai žinomas šio laikotarpio darbas - jivairiaspalvès krosnys iš koklių su Liudvikos Karolinos inicialais ir 1682 m. data. Darbai vyko lètai, pilies būklè 1686 m. nekokia:

\footnotetext{
vietos gyventojai galvijus gano ant pylimų ir griovyje, pilies provianthauzas visai tuščias $<\ldots>$ trūksta lentų bei grindlenčių, skirtų kambariams rūmuose iškloti; nèra čerpių kiauram stogui užtaisyti ir nèra kam jụ padaryti, nes puodžius užsièmęs krosnių statyba, o rūmų kambariams tinkuoti reikalingi geri meistrai. ${ }^{121}$
}

Rümai. Liudvikos Karolinos laikotarpio darbų kai kuriose patalpose pobūdis ir nemažai net iki $1704 \mathrm{~m}$. nepradètų tinkuoti patalpų rodo, kiek daug buvo likę neįrengtų rūmų kambarių. Teiginys Liudvikos Karolinos laiške J. Graurokui [dvaro paseniūniui, - E. P.] 1681 m., „,kad rūmams užbaigti nemažai plytų prireiks “122, rodo, kad liko neužbaigti net kažkokie mūro darbai. Negana to, panašu, kad dukters jau galèjo netenkinti kai kurie B. Radvilos meistrų sukurti ar projektuoti rūmų interjerai, išorès elementų sprendimai. Vienas to pavyzdžių - $1686 \mathrm{~m}$. pabaigoje numatyta didžiųjų laiptų rekonstrukcija. Senieji B. Radvilos laikų mūro laiptai turèjo būti nugriauti ir jų vietoje padètas naujas pamatas. Naujųų laiptų pamatinės ir kampinès plokštės turèjo būti iš gero Gotlando akmens, platesni ir „kiekviena pakopa vienu coliu plačiau išsikišusi“, kaip senụjų laiptų. Išdekoruoti laiptai turëjo būti arba auksu, arba dažais ir puošti dekoratyvinèmis kolonèlèmis. Po viršutiniais ir apatiniais piliastrais [galerijų? - E. P.] meistras pasižadejjo „padaryti 18 tvirtinančiu karnizų iš gero Gotlando akmens “123. Kasinėjimų metu prie rūmų surastas stačiakampis išorinių laiptų pamatas su gana gerai išlikusiomis mūrinėmis siaurų laiptų i rūsius po išorinių laiptų aikštele pakopomis ir ant jų buvusių pakopų lentų atspaudais. Atkastame išorinių laiptų pamate nebuvo projektuotų pamatų plokščių, nesimatė (ar neliko?) ir laiptų pamato pertvarkymo žymių.

Nors ne visos patalpos buvo ịrengtos, rūmai buvo su visais langais ir kone visomis durimis - natūroje, išlikusiuose mūruose likę šių elementų staktų atspaudai, daugelyje pirmo aukšto langų angų matėsi grotu 


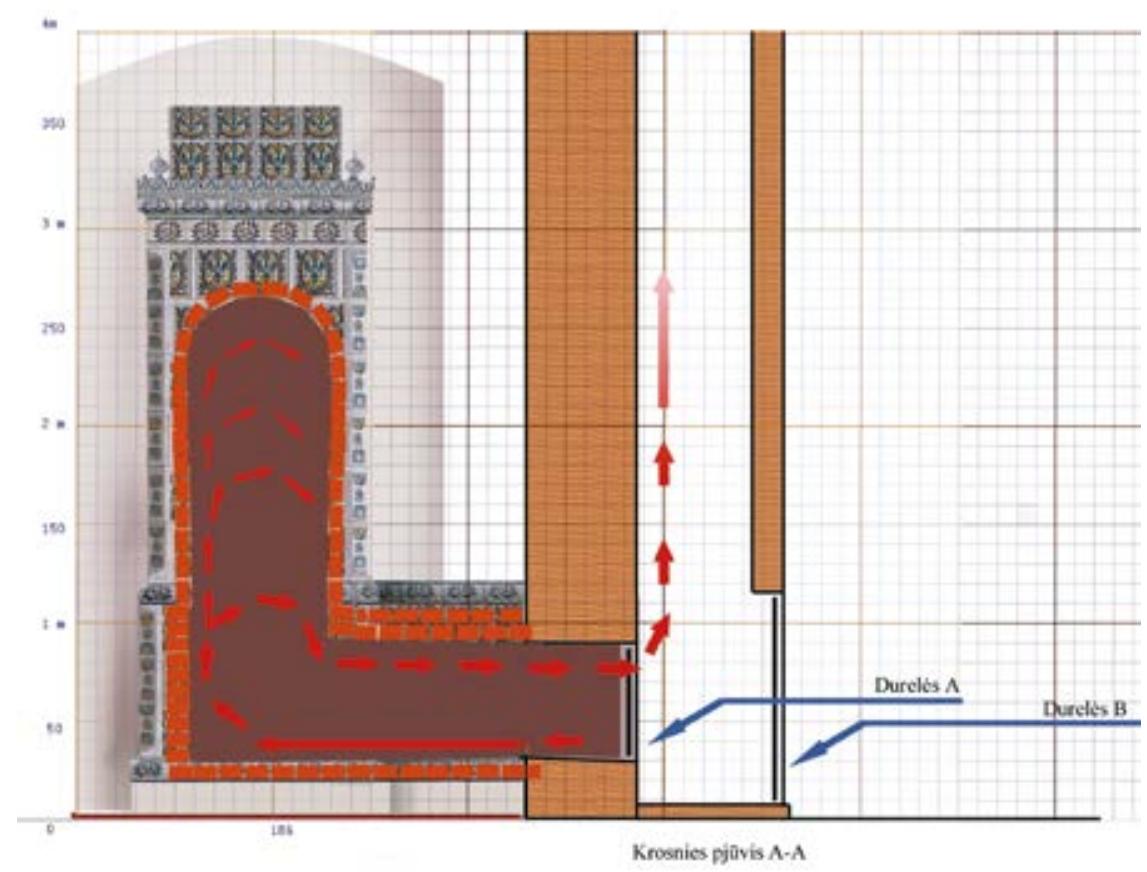

37.

Senovinio tipo krosnies atkūrimo projektas. Skersinis pjūvis su jame pavaizduota krosnies veikimo schema, rekonstrukcijos aut. Dainius Strazdas, in: $X V I-$

XVII a. koklinès krosnys šiauriniame Lietuvos

Didžiosios Kunigaikštystès paribyje: Konferencijos medžiaga, Kaunas: Žiemgalos leidykla, 2006, p. 160
Project of restoring an ancient-type stove. Crosssection with the drawing of the operation of the stove

atspaudai. Rūmų langai ir durys, laiptụ pakopos gaminti iš ąžuolo. Langu rèmai turèjo būti nudažyti pokosto dažais, kad apsaugotų nuo puvimo ${ }^{124}$.

Valant griuvenas surasta vienodos ornamentikos, tačiau ne mažiau 8 skirtingų spalvinių derinių koklių. Išsiaiškinta, kokios spalvos krosnis stovėjo konkrečioje rūmų patalpoje. Vienodų krosnių rūmuose buvo nedaug. Tik trys jų buvo vienspalvės (rudų, žalių, juodų koklių). Viršutiniuose aukštuose jų būta iš daugiaspalvių, baltų su juodais ereliais ir ịvairiaspalviais vainikais aplink erelius koklių. Vainiko spalva (mėlyna, žydra, violetinė, geltona) lèmẻ krosnies spalvinio derinio individualumą. Sveikų koklių radimvietėse gausumas rodo, kad rūmų perdangos po sprogimų ir gaisro sugriuvo 
nespėjus krosnių išsiardyti, o vieno spalvinio derinio koklių išsidėstymo griuvenose charakteris sako, kad kiekvienoje krosnyje [37 il.] buvo naudoti vieno spalvinio derinio kokliai. Griuvenų su kokliais išsidèstymas griuvenų sluoksniuose parodè, kuriame aukšte stovejjo to ar kito spalvinio derinio krosnys $^{125}$ [38 a-d il.].

Paieškos Varšuvos senujų aktu archyve rodo, kiek dar daug galima sužinoti apie pilì, rūmus, rūmų interjerus. Surasti nauji duomenys piešia nežinotus rūmų kambarių ir laiptinių interjerų vaizdus, nusako apdailos medžiagas ir pan. Atsiranda bene pirmosios, tegu ir labai fragmentiškos, žinios apie vidaus apdailos ir dekoro elementus, lubų tipus, užsakovo pageidaujamos rūmų interjerų architektūros vaizdinius. Pavyzdžiui, keturios durų staktos, pro kurias įeinama iš galerijų i i rūmus [po dvi abiejuose aukštuose, $-E . P$.], turẻjo būti padarytos iš akmens ir gražiai papuoštos ginklais bei Radvilų herbu. Virš durų galerijose, kad būtų šviesiau, papildomai iškirsti langai ${ }^{126}$. Natūroje išliko po vieną visų keturių iejeimų iš galerijų i rūmus angokraštį, tiksliau, po žemutinę angokraščio dalị [39 il.]. Visų keturių angokraščių jungtys buvo švarios, be ant jungčių krèsto skiedinio pėdsakų. Atrodo, nė vienas iš keturių portalų taip ir liko neįstatytas. Kažkur turèjo būti durys, kurių „dvejos staktos, kadangi buvo po stogu, padarytos iš akmens be didelių pagražinimų, o vienerių durų stakta - taip pat iš akmens, bet gražiai papuošta ginklais ir Radvilų herbu"127. Išlikę staktų atspaudai liudija rūmų viduje buvus tik ąžuolines durų staktas. Vienas (iš keturių) iki mūsų laikų išlikęs ąžuolinis šių staktų elementas atlaikè rūmų restauracijos darbų meto pavojus, išsaugotas montuojant ir neišlikusius staktos elementus, eksponuojamas ten, kur ir buvo ịmūrytas statant rūmus. Dabar ten administracinès muziejaus patalpos.

Arkadu galeriju galinès sienos buvo iki pamatų išgriuvusios. Tik dabar, praèjus šitiek metų po 1978-1986 m. restauracijos, sužinojome, kad galeriju galuose, abiejuose aukštuose buvo pusapvalès nišos skulptūroms. Keturiose galerijų nišose, taip pat keturiose nišose vidaus laiptų šoninėse sienose turejjo būti pastatytos Radvilų statulos. Liudvika Karolina tik turèjo nurodyti, ar jas daryti iš akmens ar gipso ${ }^{128}$. Nišų galerijų galuose dydis greičiausia buvo kaip autentiškų išlikusių abejose laiptinėse nišų. 

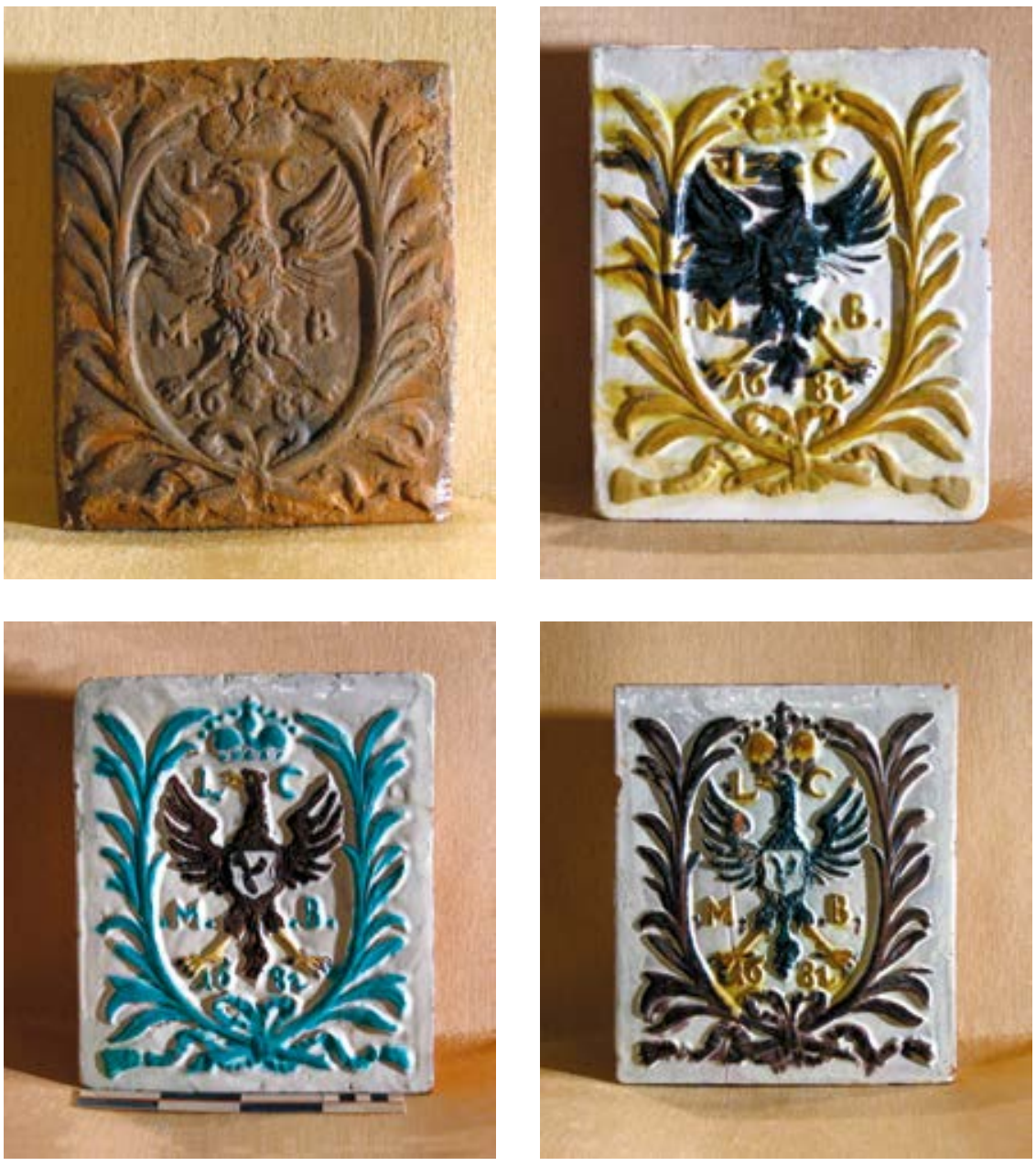

38.

1682 m. krosniu kokliu pavyzdžiai Biržu krašto muziejaus „Sėla“ rinkiniuose, Dainiaus Strazdo

Examples of stove tiles of 1682 in the holdings of the nuotraukos, 2006 


\section{Liudvikos Karolinos statybu laikotarpio interjerai ir dar šiek}

tiek žinių apie kambarių paskirtis. Kunigaikščių kambariai buvo suprojektuoti ir ịrengti rūmų centrinėje dalyje antrame aukšte. Čia yra keturi tarpusavyje sujungti kambariai, kiekviename ju - krosnis ir židinys, prie dviejų iš jų pietvakarinẻje sienoje įrengti tualetai. Iš šių kambarių per priemenes (koridorius) galima nueiti ị sales arba ị kitus gyvenamosios zonos kambarius. İkomponavimas rūmų centre, tarp reprezentacinès ir gyvenamosios rūmų zonų, rodo išskirtinị šių keturių kambarių statusą. Gana aiškiai kunigaikščių kambarių vietą rūmuose nusako grindų medžiagų rūmų priemenèse aprašymas:

Koridoriaus likutis prieš Radvilų kambarius prie sraigtinių laiptų ${ }^{129}$, kaip ir koridorius tarp didžiosios salès ir kambarių, turèjo būti išklotas pakaitomis rudomis ir pilkomis uolektinèmis plokštemis ${ }^{130}$. Pastarosios buvo nupirktos ir atgabentos iš Rygos. ${ }^{131}$

Grindys Radvilų kambariuose turèjo būti ąžuolinès, tuo tarpu kituose kambariuose - eglinès ${ }^{132}$. Taip pat suplanuoti, bet pirmame aukšte, yra dar keturi su dviem tualetais rūmų pietvakarinėje sienoje centrinès dalies kambariai, irgi turèję po du tualetus. Šių kambarių paskirtis dokumentuose nepaminèta ar neatpažinta. Pirmo aukšto galerijoje, pasak E. Tiškevičiaus, buvo lauko akmenų grindinys.

1686 m. Biržų kunigaikštystès komisarai Jurgis Chvalkovskis ir Jonas Reiteris įsakė pasamdyti naują stiklių Kurše, kad pagamintų pušines ir ąžuolines lentas grindims ir palengva jas klotų, mūrytų krosnis ir kur tik galima tą darbą baigtų iki žiemos ${ }^{133}$. Griuvenų susisluoksniavimas 1960-1961 m. atskleidè, kad rūmai sprogimų zonose sugriuvo nepalikdami galimybių išardyti krosnių. Žinios apie koklių sankaupas ir jų išsidèstymą ${ }^{134}$

129 Koridoriais to meto dokumentuose vadinamos priemenès prie laiptinių, o sraigtiniais laiptais - apie lifto šachtą dešinėje laiptinėje apeinantys trijų maršų kiekviename aukšte laiptų maršai. Kairėje laiptinėje aplink mūrinę sieną laiptinès centre sukasi dviejų maršų laiptai.

130 Muziejaus ekspozicijoje, skirtoje kasinejjimų metu surinktiems radiniams, galima pamatyti rudo ir pilko akmens grindų plokštes. Keliasdešimt tokių kiemo teritorijoje surinktų ir saugotų plokščių nežinia kur išvežta rūmų restauravimo darbų pabaigoje, apie $1985 \mathrm{~m}$. Plokščių matmenys apie $49 \times 49 \mathrm{~cm}$. Rūsiuose dalis grindų iš lauko akmenų, dalis iš keraminių $25 \times 25 \mathrm{~cm}$ dydžio plytelių.

131 Deimantas Karvelis, op. cit., 2006, p. 29.

132 Ibid.

133 Ibid.

134 Edmundas Skardžius, Atkasimo-tyrimo darbų apibendrinimas, 1961, in: VRVA, f. 5-128. 


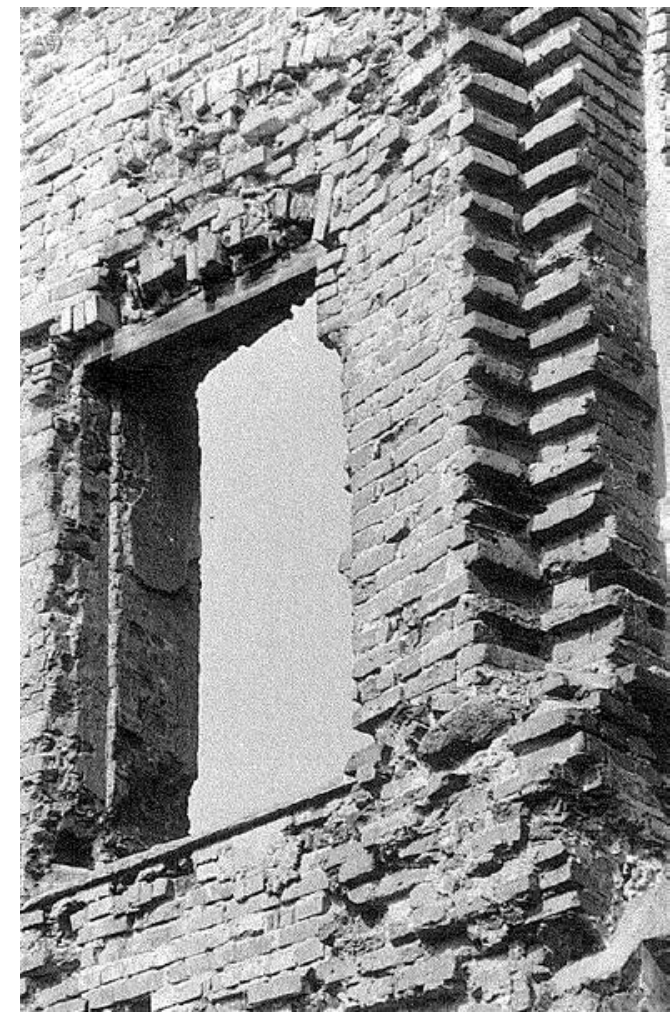

39.

Mūrijant sieną, suformuota jungtis numatytam vèliau sumontuoti portalui ir jị laikančiam mūrui prijungti. Kairejje durų anga su išlikusiu staktos viršutiniu skersiniu ir šoninių staktos elementų bei apatinio skersinio atspaudais, Evaldo Purlio nuotrauka, 1974

Connection built during the wall construction for attaching a portal and its supporting wall

2006 m. padejo nustatyti, kuriose patalpose buvo to ar kito spalvinio derinio krosnys ir kad vienoje krosnyje buvo tik vieno spalvinio derinio krosnys.

Liudvikos Karolinos statybų laikotarpiu planuota daug kambarių dekoruoti lipdiniais, tačiau nežinome, ar / kiek šis jos nurodymas buvo igyvendintas. Lipdyba turèjo puošti ir kunigaikščių kambarius. Tvarkant lubas, buvo iškilęs klausimas, kokị dekorą pasirinkti - lipdinius ar tapybą. Liudvikos Karolinos nurodymu lubos turèjo būti dekoruotos lipdiniais, ypač populiariais XVII a. pabaigoje. Tam turejjo būti naudojamas ne atvežtinis, o vietinis gipsas, kurio Biržų apylinkèse daug ${ }^{135}$. Daugiausia lipdybos galèjo būti ant antro aukšto patalpų plafonų, palubės karnizų zonose. Lubos galèjo būti puoštos lipdyba ir, panašiai kaip Skoklosterio pilyje, tiesiai ant mediniu konstrukcijų [40 il.]. 


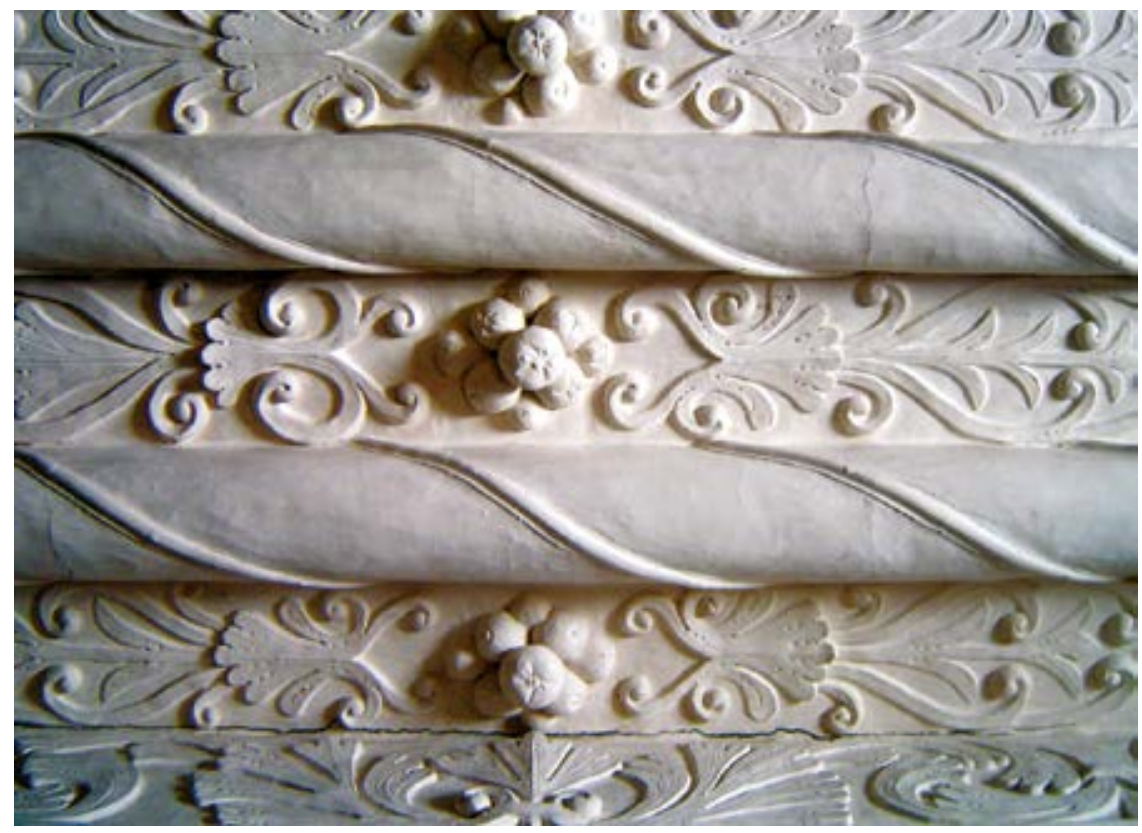

40.

Lipdybos ant lubų viename iš Skoklosterio pilies

Detail of ceiling mouldings in one of the rooms of the Švedijoje kambarių fragmentas, Evaldo Purlio Skokloster Castle in Sweden nuotrauka, 2007

Nežinia, ar Liudvika Karolina planavo rūmų interjerus ir lubų puošybą pertvarkyti pagal pasikeitusias tendencijas, ar lipdiniais išpuošti tik dar buvusius neįrengtus kambarius. Abejonių dèl puošybos lipdiniais kelia rūmų rūsių archeologų 1960-1961 m. ataskaitose neužfiksuoti lipdybos fragmentai. Tačiau žinant, kiek tuo metu sukauptų radinių pražudyta nutraukus rūmų rūsių atkasimo ir tyrimo darbus ir nepasirūpinus laikinuose sandèliukuose pilies kieme sudètais radiniais, galima spèti, kad mums rūpimi dekoro elementai galèjo būti tiesiog neišsaugoti.

Daug dėmesio Liudvika Karolina skyrė didžiosios salès ịrengimui. Norèjo, kad ji būtų panaši i Berlyno Kiopeniko rūmų herbų salę. Šios patalpos lubos, Radvilaitès nurodymu, turèjo būti ištapytos: 
Radvilų giminės žygdarbiais ir garsiais įvykiais, gražiai suformuotuose rèmuose, o sienos virš viršutinių langų - giminės geneologija ir herbu, vietos tarp viršutiniu langų [paryškinta, - E. P.] - natūraliais kunigaikščių Radvilų atvaizdais, o sienos tarp apatinių [paryškinta, - E. P.] langų iškaltos apmušalais. Vieną sieną turèjo puošti ilgas ir dailus, lipdiniais išpuoštas židinys, grindys išklotos pakaitomis baltomis ir juodomis uolektinėmis plokštėmis, kad derintųsi prie viso salès interjero. ${ }^{136}$

Panašu, kad Liudvika Karolina savo pageidavimus didžiosios salès išreiškė turėdama matytą, jai patikusios salès vaizdą, užmiršusi, kad Biržų pilies rūmuose nèra salès su dviem aukštais išdèstytais langais. Arba - tokią salę ji planavo įrengti. Sujungus antro ir trečio aukštų salių erdves Liudvikos Karolinos salès aukštis būtų padidèjęs maždaug iki 10 metrų. Deja, netinkuotos daugelio salių sienos, nepastatytos krosnys rodo, kad šie planai nebuvo nė pradèti iggyvendinti ir kiek mažai buvo pasistūmèta įrengiant kairiosios, reprezentacinès, rūmų pusès interjerus.

Pilies žütis - rümų sprogdinimas, ükinès paskirties statinių sudeginimas 1704 m. ir laikas. Praejjus daugiau nei 300 metų nuo pilies sunaikinimo, ne taip lengva rekonstruoti švedų kareivių ir jų minuotojų veiksmus - mes mateme tik tụ veiksmų pasekmes, padidintas gamtos poveikio ir žmonių savanaudiškumo. Išeidami iš Biržų, švedų kariai siekè neturèti savo užnugaryje įtvirtinimų, kuriuose priešas galètų ịsitvirtinti, panaudoti kaip atramos punktus kariuomenès ir jos komunikaciju puldinèjimams, o artinosi rusų pajègos. Generolas majoras A. L. Lewenhauptas paliko majorą Gerteną su kokiu šimtu vyrų, kad išardytu ittvirtinimus ir susprogdintų pilit, ką šis vos ne vos spejjo atlikti iki rusų atėjimo ${ }^{137}$. Netrukus panašus likimas ištiko ir Bauskès pilį. Griauta deginant ir sprogdinant. Pradètą darbą tęsè laikas, gamta ir žmonès. Sugriuvo priekinè rūmų siena, neliko mažesniuju pilies statinių [41-43 il.].

$1750 \mathrm{~m} .:$

îvažiuojant iš miesto buvo 8, o dabar 7 stulpai, mūryti iš plytų, ant kurių kadaise buvo ąžuolinis tiltas, ten pat vartai su rūsiais, mūryti iš plytų, visai iš pamatų

136 Ibid

137 A. L. Lewenhaupto pasakojimas su priedais, išleido karališkoji Skandinavijos istorijos rankraščių leidybos draugija, parengè S. E. Bringas, in: Istoriniai raštai, t. 34:2, Stokholmas, 1952. Vertimas ị lietuvių kalbą Biržų krašto muziejuje „Sėla“. 
sugriauti. Einant toliau tiesiai ị kiemą, rūmai su rūsiais prie Agluonos upès, mūryti iš plytų, apgriuvę ir virsta griuvėsiais. Prie jų ceikhauzas, mūrytas iš plytų, tik sienos stovi, visas apgriuvęs. ${ }^{138}$

1960-1961 m. atkasant rūmų rūsius pasimatè, kad rūmai sprogdinti bent dviem užtaisais. Vienas jų buvo prie kairiojo rizalito pietryčiu fasado, antras - dešiniojo rizalito viduje. Apie $1983 \mathrm{~m}$. tiesiant šilumos trąsą atsidengė trečio užtaiso vieta - prie pirmo iš kairès arkadų galerijos stulpo [44 il.]. Užtaisų, ypač dešiniajame rizalite, būta galingu - čia sugriuvo ir iš vietos pasislinko net dalis dešiniojo rizalito rūsio sienų, o jų storis per du metrus. Nuo sprogimo prie galerijos sugriuvo galerijos, didžiosios salès kairiojo rizalito pirmame aukšte skliautai. Rūsiuose atsidūrè centrinės rūmų dalies patalpose stovejję pirmo ir antro aukštų krosnys. I rūsius suvirto ir dešiniojo rizalito krosnys, sienų luitai. Po tokių sugriovimų turëjo suvirsti antro ir trečio aukštų perdangos, didžioji dalis stogo konstrukcijų. Kilo gaisras. Stebina, kaip per abu aukštus išsilaikè fasadinė siena galerijos gilumoje ir visos centrinės dalies sienos. Centrinės rūmų dalies skliautai upės pusejje, prie išlikusios ilgosios fasadinės sienos, atrodo, nesuvirto - gal tik tuo galima paaiškinti, kodèl čia nerasta tokių krosnių. Matyt, buvo galimybe šias krosnis išsiardyti. Nesuvirto laiptinès. Šiandien negalima pasakyti, kas išgelbẻjo centrinès rūmų dalies sienas - sprogdintojų neatidumas, apsiskaičiavimas ar nesprogęs užtaisas. Praejjus trims šimtams metų, sunkoka ịsivaizduoti, kaip atrodè rūmai iškart po sprogimų ir gaisro, bet vargu ar galima patikèti, kad rūmuose galèjo būti likę tinkamų gyventi kambarių.

Kiti statiniai sudeginti. Kasinėjimų metu rastos išdegusios arsenalo medinės grindys, degėsių rasta pietiniame ir vakariniame bastionuose kasinètų kareivinių grindų lygyje. Vienose iš vakariniame bastione buvusių kareivinių rastos ir apdegusių durų liekanos. Nebesulaukus dar vienos pilies restauracijos, išlikusias pilies statinių sienas ėmė pamažu ardyti laikas ir žmonès. Sugebèta išardyti (tiesa, tik iš dalies) ir pusiau požemines parakines bastionų kampuose. Žemės pylimus labiausiai veikè laikas, priežiūros stoka, netinkamas panaudojimas. Paskutinė didesnė pilies mūrų ardymo banga praėjo per Pirmajị pasaulinị karą ir netrukus po jo. 


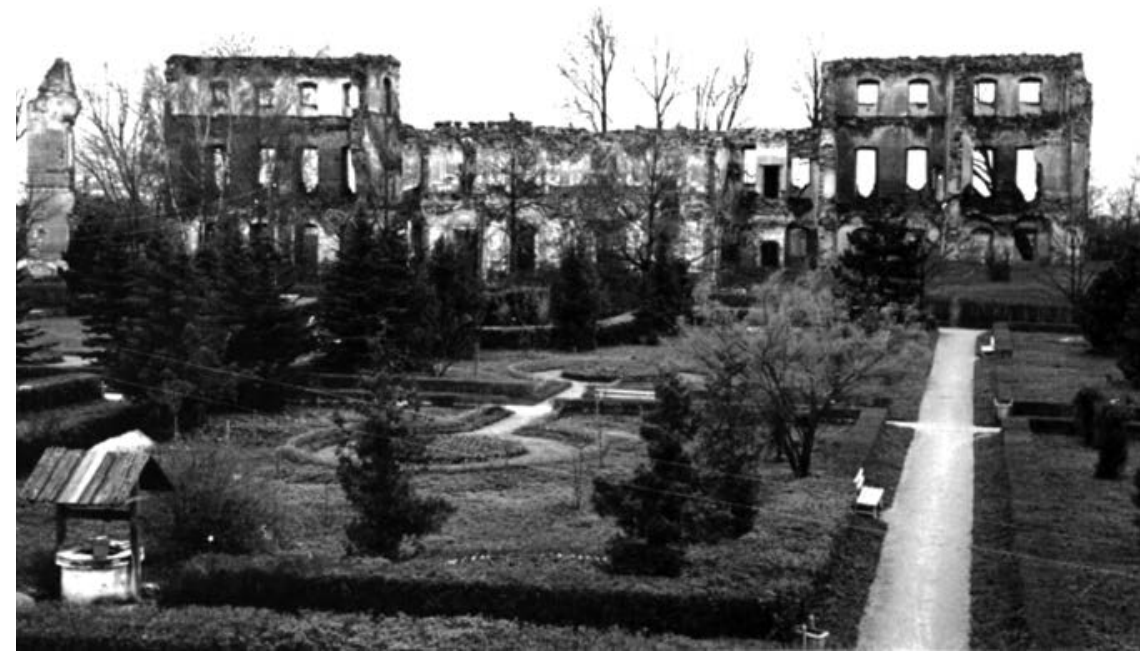

41.

Rūmų vaizdas iki konservacijos, apie 1950-1955

View of the palace before conservation, ca. 1950-1955

\section{Biržų pilies gynybinių pylimų apsauga ir tvarkyba, pilies statinių restauravimas, atkūrimas}

Biržų ir Dubingių Radvilu šakos nuosavybèje pilis išbuvo iki 1731 m., kai Biržus ir jų turtus nupirko Nesvyžiaus Radvilų šakos atstovas Jeronimas Florijonas. $1811 \mathrm{~m}$. paskutinysis Radvilu giminès atstovas Biržuose Dominykas Radvila juos pardavė grafui Juozui Tiškevičiui. 1922 m., remiantis žemès reformos ịstatymu, pilies rūmų griuvėsiai ir teritorija nusavinti, perduoti prižiūrèti Biržų miesto valdybai ir Lietuvai pagražinti draugijos Biržų skyriui. Rūpesčius, saugant ir tvarkant pili bei joje stūksančius griuvėsius, perėmė visuomenė, valstybè, bet praèjo daugiau nei 30 metų, kol buvo imtasi realių pilies statinių liekanų gelbèjimo darbų ${ }^{139}$. Šiais darbais prasidèjo naujas pilies statybų etapas, atverstas naujas pilies funkcionavimo puslapis.

Rūmų liekanų gelbèjimas prasidèjo 1951 m., t. y. nuo pirmojo išlikusių rūmų sienų konservacijos projekto ${ }^{140}$ parengimo. Pradžią pilies atgimimui padarè rūmų sienų tvirtinimo - dalinès restauracijos darbai, kurie

140 Simonas Ramunis, Radvilų pilies Biržuose konservavimo projektas, 1951, in: VRVA, 


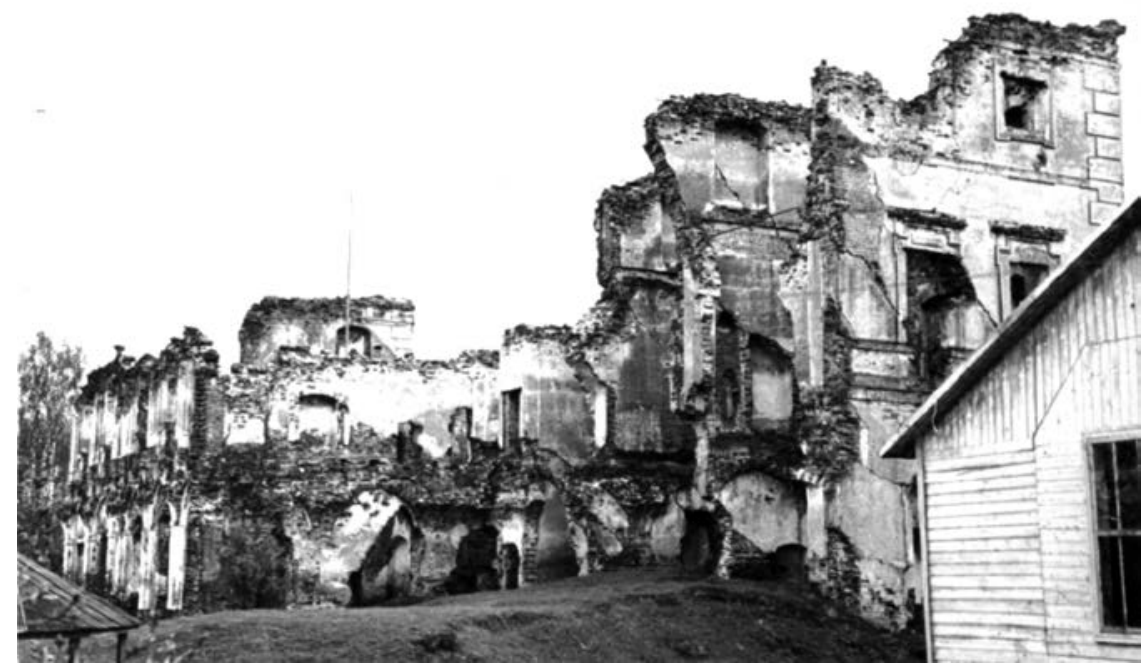

42.

Rūmų vaizdas iki konservacijos, apie 1950-1955

View of the palace before conservation, ca. 1950-1955

prasidèjo 1955 m. ${ }^{141}$, kai buvo sutvirtintos sienos, iš dalies restauruoti labiausiai apirę langų ir durų angokraščiai išlikusiose rūmų sienose, užmūrytos šiose sienose žiojëjusios skylès, o virš dalies rūmų sienų padaryti apsauginiai stogeliai. Šiais darbais buvo gerokai pristabdytas mūrų irimo procesas, tačiau ir toliau pamažu krito tinkas, nyko sandrikų ir karnizų profiliai, židinių apvadai, skliautų mūrų liekanos, nuo neuždengtų sienų krito plytos, akmenys. Raštai nuo 1956-ujų jau atspindi norus ir pastangas atstatyti ir panaudoti naujai paskirčiai Biržu pilies rūmus. Deja, aplinkybès igyvendinti šiuos siekius buvo pernelyg sudètingos.

Pilies statiniu restauravimas prasidejo tilto per fosą atstatymu tik apie 1973 metus $^{142}$. Atstačius tiltą buvo sudaryta galimybė ị pilies kiemą ìvažiuoti statybinei technikai. Parengtas rūmų restauravimo ir pritaikymo Biržų kraštotyros muziejui ir rajoninei bibliotekai projektas ${ }^{143}$. Ilgai laukta rūmų restauracija prasidejjo $1978 \mathrm{~m}$. ir truko iki 1986 m. ${ }^{144}$ [45 il.].

141 Evaldas Purlys, „50 metų Biržų pilies restauracijai“, p. 102-119.

142 Napalys Kitkauskas, op. cit., p. 136-156.

143 Evaldas Purlys, Biržų kraštotyros muziejus ir rajoninė biblioteka (buv. Biržų pilies rūmai), Eskizinis projektas, 1975, in: VRVA, f. 2-52-18; Evaldas Purlys, Danutė Gižienė, Biržų kraštotyros muziejus ir rajoninė biblioteka (buv. Biržų pilies rūmai), Techninis darbo projektas, t. 1, Architektūrinè statybinè dalis, 1976, in: VRVA, f. 2-52-19.

144 Evaldas Purlys, „Biržų pilies rūmų restauracija 1978-1987 m.“, p. 120-125. 

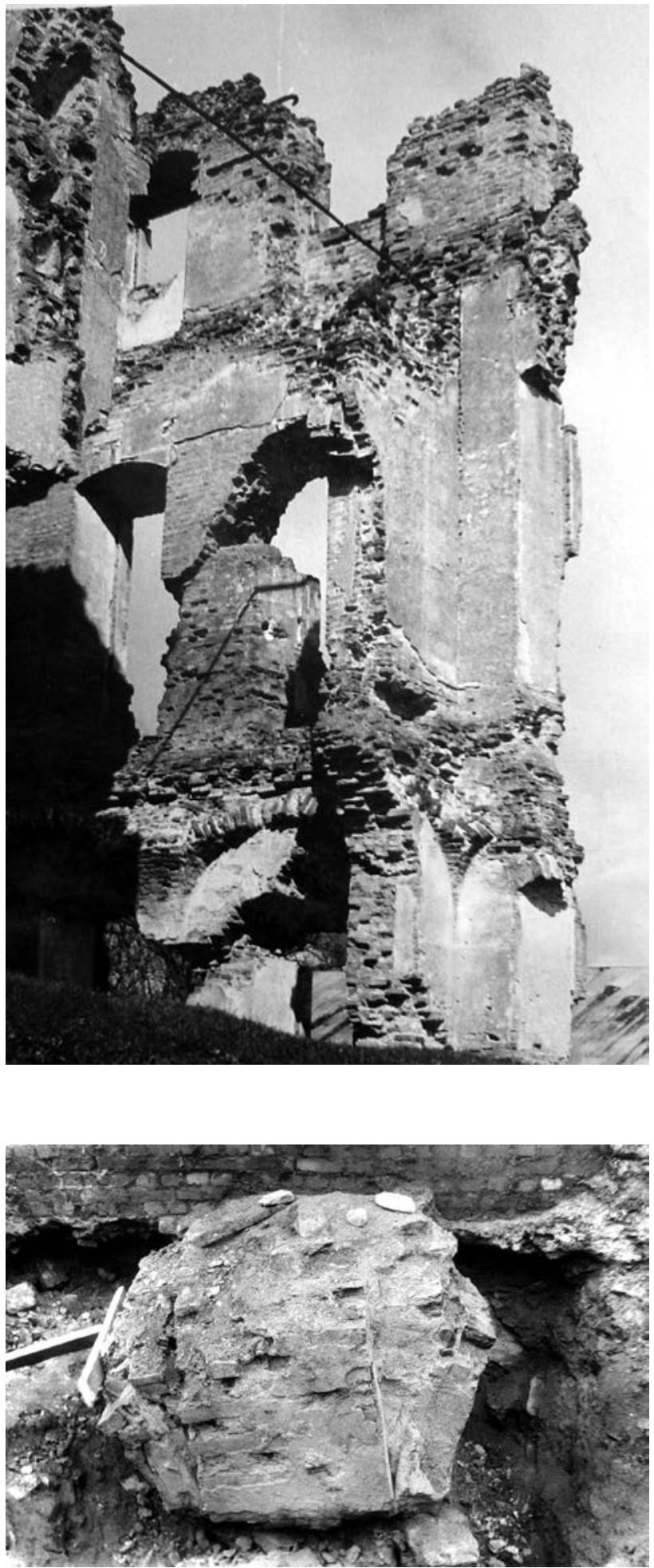

43.

Rūmų dešinio rizalito sienos iki konservacijos, apie 1950 1955. Nuirus vidinès sienos mūrui, atsidengè metalinè sienas tvirtinanti templè. Išorinę sieną tvirtinančios templès fragmentas matyti šios sienos viršuje

Walls of the right avantcorps of the palace before conservation, ca. 1950-1955

\section{4.}

Vienas iš į sprogimo duobę $1704 \mathrm{~m}$. suvirtusiu arkados stulpo luitu. Priekyje matyti arkos apvado profilis, Evaldo Purlio nuotrauka, apie 1983

One of the pieces of the arcade pillar that collapsed into an explosion pit in 1704. The profile of the arch surround can be seen in the front 
Rūmų pastatas, nors didelis ir atrodè sudètingos struktūros, buvo vienas iš lengviau restauruojamų pastatų pilyje. Labai padejo vienintelis turimas pilies pastatų vaizdas su aiškiai pavaizduota rūmų tūrių kompozicija, stogu ir jo architektūriniais elementais [46 il.]. Išlikusiose sienose matèsi rūmų sienų ir vidaus erdvių išdėstymo struktūra. Nesudarẻ sunkumų rūsių ir pirmo aukšto patalpų skliautų, fasadų architektūros bei puošybos restauravimas. Interjero ir kitų nežinomų elementų projektavimo metodinę kryptị lèmė žinių apie šiuos elementus stoka, ano meto galimybès ir, svarbiausia, nuostata restauruoti tik tuos elementus, kurių restauravimą buvo galima visapusiškai pagrịsti, o nežinomų ar mažiau žinomų elementų restauravimą atidèti vèlesniam laikui, kai bus surinkta pakankamai šių elementų atkūrimą pagrindžiančios medžiagos. I 1978-1987 m. restauraciją žiūrèta kaip i pirmą rūmų restauravimo-atkūrimo etapą. Medžiagų gavimo galimybès anuo metu neleido iš „gero Gotlando smiltainio“ pagal autentiškus pavyzdžius pagaminti turèklų, baliustrų, piliastrų bazių ir kapitelių. Teko lieti iš betono, istoriškai nepagrịsta medžiaga granitas panaudotas vietoj raudono klintinio akmens vestibiuliuose ir pan.

Kartu su rūmais buvo tvarkomi keli smulkesni pilies statiniai, pašalinta nemažai savaiminių ar neapdairiai kasmet pokariu vykusių medžių sodinimo kampanijų metu prisodintų medžių ${ }^{145}$ [47 il.]. I restauruotus rūmus 1986 m. persikèlè Biržų rajoninė biblioteka, o kiek vėliau - Biržų krašto muziejus „Sèla“. Tik apie $2012 \mathrm{~m}$. kairiojo rizalito rūsio patalpose įsikūrè kavinè ${ }^{146}$. Nepakankamai tvirtai suręstą tiltą teko perstatyti $2002 \mathrm{~m} .{ }^{147}$ [48 il.]. Per metus, praejjusius po rūmų atstatymo, papildomai tvirtinti rūmų pamatai ir sienos ${ }^{148}$, irengta lietaus vandens nuvedimo sistema, perdengtas stogas, pakeisti langai ${ }^{149}$. 2010-2012 m. buvo atkurtas arsenalo pastatas ${ }^{150}$.

145 Algis Knyva, Buv. Biržų pilis, Teritorijos sutvarkymo sprendimai, 1986, in: VRVA, f. 2-52-64; 2-52-65; 2-52-66; Evaldas Purlys, Biržų pilis, Gynybinių pylimų atidengimo ir želdinių retinimo projektas, 1992, in: VRVA, f. 2-52-79.

146 Nijolè Ščiogoliovienè, Evaldas Purlys, Pilies rūmų (u. k. 22835) pastato dalies patalpų paskirties keitimas ị maitinimo pritaikant kavinei techninis projektas, 2010, in: VI „Lietuvos paminklai“ informaciniai fondai.

147 Evaldas Purlys, „Biržų pilies tiltas“, in: Lietuvos keliai, 2002, Nr. 2, p. 70-73.

148 Nijolè Ščiogoliovienè, Jelena Parasonienè, Biržų pilies rūmų G54K1P tyrimai, sienų ir pamatų sutvirtinimo techninis projektas, 2005, in: VI „Lietuvos paminklai“ informaciniai fondai.

149 Nijolè Ščiogoliovienė, Biržų pilies rūmų langų pakeitimas, 2009, in: UAB Projektavimo ir restauravimo instituto informaciniai fondai, f. 2-1908-2/29706.

150 Nijolè Ščiogoliovienè, Evaldas Purlys, Biržų pilies arsenalo pastato atkūrimas ir pritaikymas turizmo ir kt. viešiesiems poreikiams, 2009, in: UAB Projektavimo ir restauravimo instituto informaciniai fondai, f. 2-1908-2; 2-1908-5. 


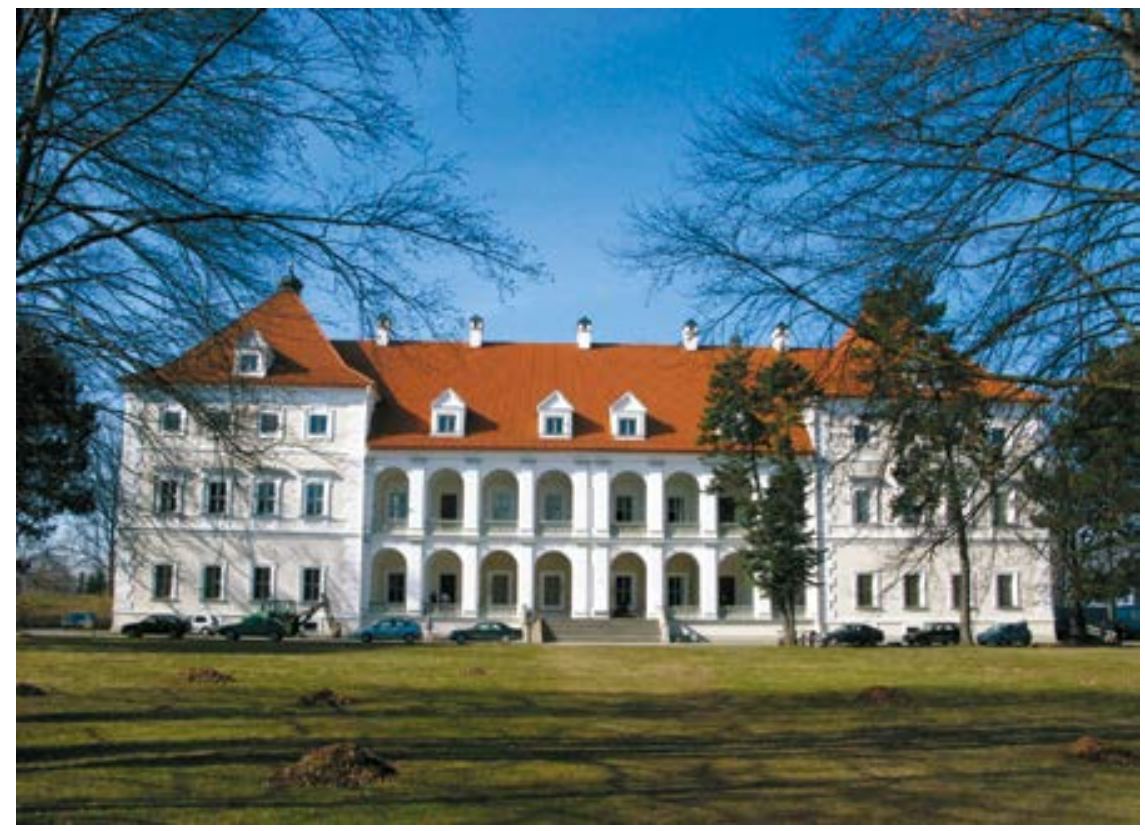

45.

Pilies rūmų pagrindinis fasadas, Evaldo Purlio Main façade of the castle's palace nuotrauka, 2009

1978-1987 m. projektuojant pakabinamas lubas, grindis, duris pasirinktas nežinomų elementų piešinio modernizavimo kelias, tikintis, kad jis yra daugiau ar mažiau laikinas, kad iki būsimų remontų bus rasti papildomi rašytiniai šaltiniai, kuriais remiantis atkūrus kai kuriuos interjerų elementus galima būtų kai kurioms rūmų patalpoms suteikti daugiau XVII a. vaizdo. Panaudojus tuos elementus galima bus pailiustruoti bent kai kuriuos interjerų dekoro sprendimus. Kai ką patikslinti jau galime - neseniai sužinota apie nišas galeriju galuose ir apie Liudvikos Karolinos siūlytus kirsti langus virš keturių ịejjimų iš galerijų i rūmus, $2006 \mathrm{~m}$. atstatyta viena iš Radvilų kambariuose stovèjusių krosnių ${ }^{151}$.

Intensyvi muziejaus ir bibliotekos veikla, kruopšti pastatų ir teritorijos priežiūra padarė Biržų tvirtovę vienu patraukliausių atvertų objektų Lietuvos istorijai pažinti. Muziejaus lankytojų skaičius pasiekė daugiau kaip 60 tūkst. per metus. Pasirinkta pilies tvarkybos kryptis pasiteisino, tačiau

151 Dainius Strazdas, „Antrosios pilies rūmų koklinės krosnies tyrimai ir rekonstrukcija“, in: XVI-XVIIa. koklinès krosnys šiauriniame Lietuvos Didžiosios Kunigaikštystès paribyje: Konferencijos medžiaga, Kaunas: Žiemgalos leidykla, 2006, p. 67-119. 


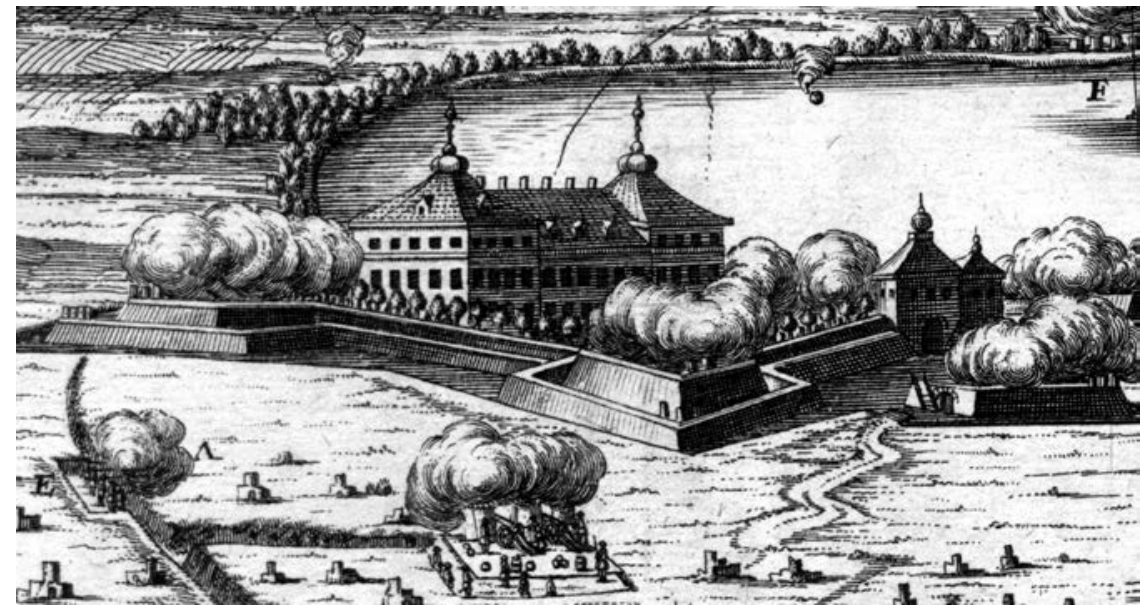

46.

Pilies rūmai $1704 \mathrm{~m}$. pilies apgultị vaizduojančioje švedų graviūroje

Castle's palace in the Swedish engraving representing the castle's siege of 1704

pilies ir jos tvarkytojų laukia dar labai daug darbų ir iššūkių. Nežiūrint visu pastangų, dar toloka iki užbaigto, visuomenei atviro ansamblio vaizdo, dar ne iki galo atverta gynybinè tvirtovès struktūra, ypač gynybinių pylimų architektūra, redutas. Vienas didesnių, o kartu ir sudètingesnių darbų - fosu tyrimas ir valymas. Laukia eilès ir galimybių vartų pastato, kareivinių ir kitų statinių bei jų liekanų tvarkyba. Nebetenkina laikinasis vartų pastato liekanų apsaugos sprendimas. Visi būsimi darbai sukelia ne vien techninio pobūdžio sunkumus ar finansavimo problemas. Kiekvienas iš vienokių ar kitokių sprendinių turi būti pagrịstas visapusiškais tyrimais. Visų pirma archeologiniais, istoriniais. Nuo to priklauso architektūrinis sprendinių profesionalumas ir patikimumas, autentiškumo išsaugojimo sėkmè.

\section{Vietoj išvadų}

Darbas, renkant medžiagą šiam straipsniui, parodè, kiek jau daug žinome apie pilies statinių architektūrą, o kartu ir kiek dar daug galètume sužinoti, jei būtų nuosekliau ieškoma dar neskaitytų dokumentų, jei būtų dar ir dar kartą perskaitomi net mūsų archyvuose saugomi, ne kartą žiūrèti dokumentai. Istorinių tyrimų svarbą neseniai pademonstravo arsenalo 


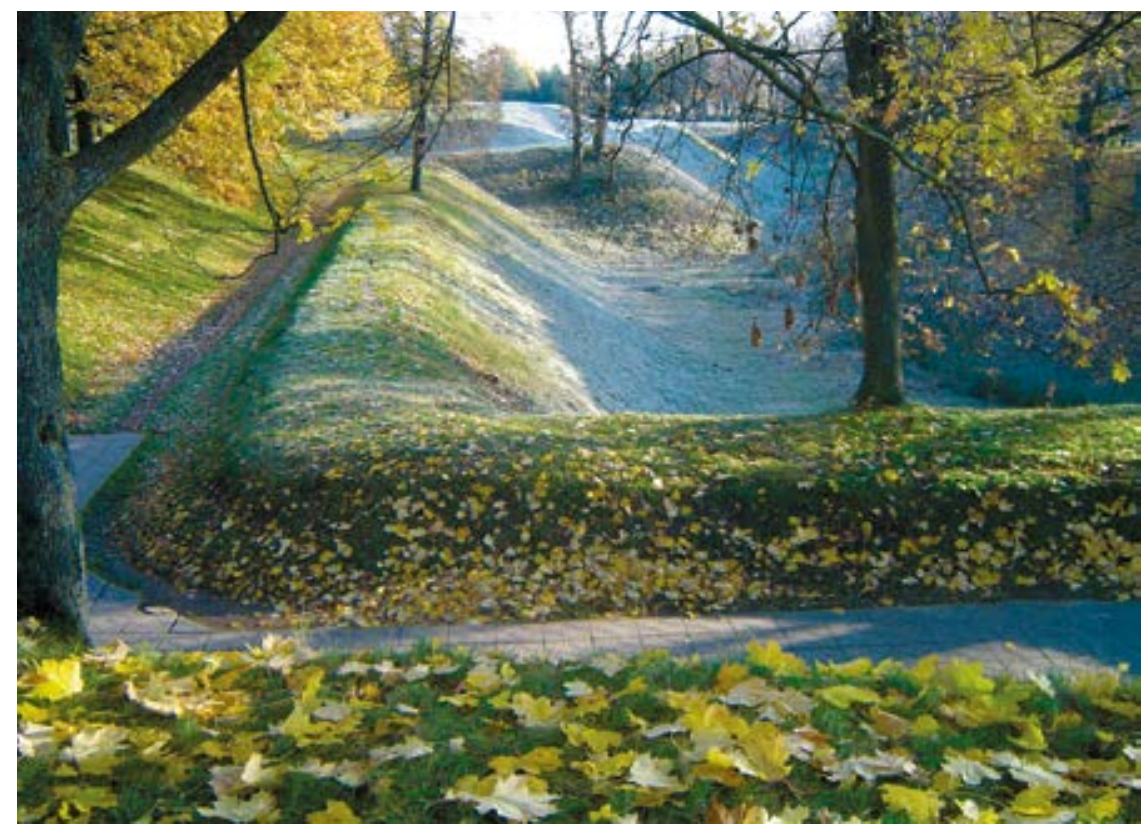

47.

Gynybiniai pilies pylimai pašalinus dalį medžių, iš dalies restauravus šaulių pylimèlio fragmentą, Evaldo Purlio nuotrauka, 2007
Defensive ramparts of the castle after some trees were removed and a fragment of the riflemen's rampart was partially restored

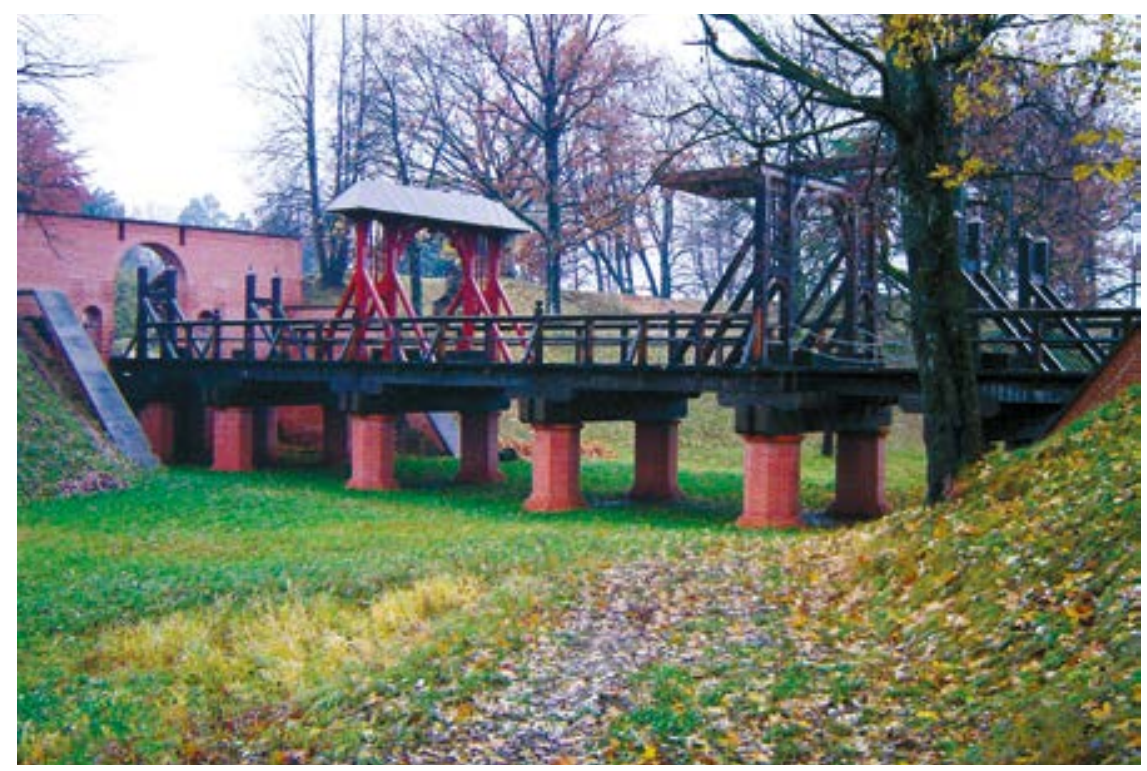

48.

2002 m. perstatytas pilies tiltas, Evaldo Purlio nuotrauka, 2004
Castle's bridge rebuilt in 2002 
atkūrimas. Deja, net istoriniai tyrimai vis dar vykdomi priešokiais, nauju istorinių žinių apie statinių architektūrą paieška vis dar nenuosekli, galimybẻ paskubom žvilgtelèti ị archyvų lentynas atsiranda tik prireikus patvarkyti ar atstatyti kurị nors pilies teritorijoje buvusị statinį. Tad lieka tikètis ir linkèti naujų pilies statinių tvarkybos darbų, naujų archeologinių tyrimų ir atradimų, istorikų išvykų i užsienio archyvus. $O$ baigiant straipsnị norisi priminti, kad vis dar nerasta nè vieno pilies statytojų korespondencijoje paminèto projekto [paryškinta, - E. P.], neturime Eustachijaus Tiškevičiaus paminètų dokumentų, kuriuose yra „piešinių ir paaiškinimų apie pagrindinio pastato išorę, bokštus ir vidaus papuošimus iki smulkiausių detalių“152.

Gauta -20200921

152 Eustachijus Tiškevičius, Biržai. Žvilgsnis i miesto, pilies ir majorato praeiti, Šiauliai: Saulès delta, 1998, p. 6; vertimas iš Eustachy Tyszkiewicz, Birźe, rzut oka na przeszlosc miasta, zamku i ordynacyi, St.-Petersburg, 1869. 


\section{Rankraštiniai šaltiniai}

B. Radvilos 16640723 laiškas Arciševskiui, in: AGAD, sygn. 772, p. 5; elektroninè dokumento kopija Biržų krašto muziejuje „Sèla“.

D. Kosciuška B. Radvilai, 166605 16, 166606 19, in: LVIA, f. 148, b. 2, 1. 24, 26.

Karvelis Deimantas, Biržų pilies komplekso istoriniai tyrimai, 2008, in: VI „Lietuvos paminklai“ informaciniai fondai, b. LP-176 (K-2008).

K. Karliko 16640731 laiškas B. Radvilai, in: LMAVB RS, f. 31-948.

Knyva Algis, Buv. Biržų pilis, Teritorijos sutvarkymo sprendimai, 1986, in: VRVA, f. 2-52-64; 2-52-65; 2-52-66.

Mekas Karolis, Biržų pilis (1963 m. spaliolapkričio mèn. tyrimų ataskaita), in: VAA, f. 5-206.

Mekas Karolis, Biržų pilies tyrimas, 1964, in: VRVA, f. 5-185.

Mekas Karolis, Biržų pilies tyrimas, 1965, in: VRVA, f. 5-227.

Purlys Evaldas, Biržų pilis: pilies pastatai kieme archeologinių tyrimų duomenimis, 1993, in: VRVA, f. 5-5635.

Purlys Evaldas, Biržų kraštotyros muziejus ir rajoninė biblioteka (buv. Biržų pilies rūmai), Eskizinis projektas, 1975, in: VRVA, f. 2-52-18.

Purlys Evaldas, Gižienè Danutè, Biržų kraštotyros muziejus ir rajoninė biblioteka (buv. Biržų pilies rūmai), Techninis darbo projektas, t. 1, Architektūrinè statybinė dalis, 1976, in: VRVA, f. 2-52-19.

Purlys Evaldas, Biržų pilis, Gynybinių pylimų atidengimo ir želdinių retinimo projektas, 1992, in: VRVA, f. 2-52-79.

Ramunis Simonas, Radvilų pilies Biržuose konservavimo projektas, 1951, in: VRVA, f. 2-52-01.

Skardžius Edmundas, Atkasimo-tyrimo darbų apibendrinimas, 1961, in: VRVA, f. 5-128.

Ščiogoliovienè Nijolè, Parasonienè Jelena, Biržų pilies rūmų G54K1P tyrimai, sienụ ir pamatų sutvirtinimo techninis projektas, 2005, in: VI „Lietuvos paminklai“ informaciniai fondai.

Ščiogoliovienė Nijolè, Biržų pilies rūmų langụ pakeitimas, 2009, in: UAB Projektavimo ir restauravimo instituto informaciniai fondai, f. $21908-2 / 29706$.

Ščiogoliovienė Nijolè, Purlys Evaldas, Biržų pilies arsenalo pastato atkūrimas ir pritaikymas turizmo ir kt. viešiesiems poreikiams, 2009, in: UAB Projektavimo ir restauravimo instituto informaciniai fondai, f. 2-1908-2; 2-1908-5.

Ščiogoliovienė Nijolè, Purlys Evaldas, Pilies rūmų (u. k. 22835) pastato dalies patalpu paskirties keitimas ị maitinimo pritaikant kavinei techninis projektas, 2010, in: VI „Lietuvos paminklai“ informaciniai fondai.

T. Spinovskio 16640120 laiškas, in: LMAVB RS, f. TF-3, 1, 52, 53.

Urbštas Algimantas, Buv. Radvilų pilis Biržuose, Tyrimai natūroje, t. IV-VIII, 1961, in: VRVA, f. 5 , b. $73,75 \mathrm{a}, 75,93,96,98$.

\section{Publikuoti šaltiniai}

Tiškevičius Eustachijus, Biržai. Žvilgsnis $i$ miesto, pilies ir majorato praeiti, Šiauliai: Saulès delta, 1998.

\section{Literatūra}

Genys Jonas, „1984-1985 m. archeologiniu kasinėjimų Biržų pilyje rezultatai“, in: Architektūros paminklai, t. 11, Vilnius: Mokslas, 1988, p. 45-51.

Genys Jonas, Baublys Arūnas, „Biržų pilis ir miesto itvirtinimai“, in: Lietuvos piliu archeologija, Klaipėda, 2001, p. 199-225.

Karvelis Deimantas, „Antrosios Biržų pilies (1659-1695) rūmų statyba ir interjero bei eksterjero kūrimas", in: XVI-XVII a. koklinès krosnys šiauriniame Lietuvos Didžiosios Kunigaikštystès paribyje: Konferencijos medžiaga, Kaunas: Žiemgalos leidykla, 2006, p. 17-36.

Karvelis Deimantas, „Bastioninès Biržų pilies 
arsenalas XVI-XVII a.“, in: Karo archyvas, t. XXIII, Vilnius: Lietuvos karo akademija, 2008, p. 39-73.

Kitkauskas Napalys, „Biržų antrosios pilies pylimai, fosa, redutas, tiltas“, in: Architektūros paminklai, t. 3, 1975, Vilnius: Mokslas, p. 136-156.

Lietuvos dailininkužodynas, t. I: XVIXVIII a., sud. Aistė Paliušytė, Vilnius:

Kultūros, filosofijos ir meno institutas, 2005.

Mekas Karolis, „Biržai“, in: Mokslas ir gyvenimas, 1966, Nr. 7, p. 30-33.

Pinkus Stasys, „Biržų pilis“, in: Lietuvos pilys, Vilnius: Mintis, 1971, p. 245-276.

Pinkus Stasys, Biržu pilis, Vilnius: Mintis, 1986.

Purlys Evaldas, „Biržų pilies tiltas“, in: Lietuvos keliai, 2002, Nr. 2, p. 70-73.

Purlys Evaldas, „Biržų pilies rūmų restauracija 1978-1987 m.“, in: XVI-XVII a. koklines krosnys šiauriniame Lietuvos Didžiosios Kunigaikštystès paribyje: Konferencijos medžiaga, Kaunas: Žiemgalos leidykla, 2006, p. 120-126.

Purlys Evaldas, „Šildymo įrenginių išdèstymas Biržų pilies rūmuose“, in: XVI-XVII $a$. koklines krosnys šiauriniame Lietuvos Didžiosios Kunigaikštystès paribyje: Konferencijos medžiaga, Kaunas: Žiemgalos leidykla, 2006, p. 58-66.

Purlys Evaldas, „50 metų Biržų pilies restauracijai“, in: XVI-XVII a. koklines krosnys šiauriniame Lietuvos Didžiosios Kunigaikštystès paribyje: Konferencijos medžiaga, Kaunas: Žiemgalos leidykla, 2006, p. 102-119.

Rakutis Valdas, „Biržų tvirtovès karinė reikšmė ir efektyvumas“, in: Biržu istorijos apybraižos, Vilnius: Danielius, 2006, p. 49-63.

Songailaitė Roma, Niedvarienè Tatjana, „Biržų pilies archeologiniai tyrimai“, in: Biržu pilies ir senamiesčio archeologiniai rinkiniai: nuo seniausiu laiku iki XIXa. pradžios: Katalogas, Biržų krašto muziejus „Sèla“, 2016, p. 12-15.

Strazdas Dainius, „Antrosios pilies rūmų koklinès krosnies tyrimai ir rekonstrukcija“, in:
XVI-XVII a. koklinès krosnys šiauriniame Lietuvos Didžiosios Kunigaikštystès paribyje: Konferencijos medžiaga, Kaunas: Žiemgalos leidykla, 2006, p. 67-119.

Trzeciak Przemysław, 1000 tajemnic architektury, Warszawa: Nasza księgarnia, 1988.
97 2020

Acta Academiae Artium Vilnensis 


\title{
Summary
}

\section{The Architecture of the Buildings of the Biržai Castle and Its Development}

\author{
Evaldas Purlys
}

Keywords: Biržai castle, history, architectural research, conservation, restoration, heritage.

From the construction of the first Biržai Castle in 1586-1589, this representational ensemble was expanded and rebuilt by five generations of the Radziwiłł family: Krzysztof I (1586-1589), Krzysztof II (1627-1640), Janusz (1640-1655), Bogusław (1661-1669), and Ludwika Karolina (ca. 16811686). Krzysztof II Radziwiłł restructured the castle's fortifications built by Krzysztof I Radziwiłł according to the model of Italian bastion forts into Dutchtype fortifications, but he did not finish building all structures necessary for the functioning of the castle before his death. One of the major projects of Janusz Radziwiłł who continued the works was starting to build a palace designed by J. Ulrich. The composition of the buildings in the castle's courtyard must have taken shape at that time as well. The size of the palace walls determined the composition of the structures built in the courtyard later, as well as the final view of the palace architecture, which was corrected while the works were already in progress. The buildings in the courtyard were built or reconstructed by Bogusław Radziwił’'s builders according to a new castle plan corrected by T. Spinowski in 1661-1669. Barracks and powder houses were built, the gate house was expanded, and the palace and the arsenal were roofed. Unfortunately, like the previous owners, Bogusław did not live long enough to see the finished castle. His daughter Ludwika Karolina mostly took care of the palace interiors, which remained unfinished until the castle was destroyed. The larger part of the rooms in the left avant-corps were not even plastered. Historical research and excavations provide the most information about the buildings constructed by Bogusław Radziwiłł, the height of the façades of the 
palace designed by J. Ulbricht, and an attic of a quite complex structure designed above the two-storey palace. In the final stage of the construction, it was planned to build vaults over more rooms, and there were hesitations if the second floor should be built above the entire building or only above the avantcorps. There are remaining traces of restructuring the stairways, while the thicker walls of the avant-corps at the top testify to the transformation of the attics into the second floor.

300 years after the destruction of the castle in 1704, we can talk about the new, sixth stage of the development of the architecture of the castle's buildings from 1955 until today. The tracing, research and preservation of the old buildings, the restoration of their former architecture and its constructions has become very important. We learn from historical sources about the huge significance of a large number of projects prepared by architects in the construction of the buildings in all periods. Sometimes, scale models were also used. The work of collecting the material for this article showed how much we already know about the architecture of the castle's buildings and how much remains to be discovered. What needs to be done is more consistently looking for new documents, rereading the known documents, even those held in our archives. Time has come to conduct improvement works on the defensive ramparts, the gate building and the barracks, to explore and clean the moat. The redoubt is also waiting for research and improvement. 